\title{
What is the evidence that invasive species are a significant contributor to the decline or loss of threatened species?
}

Philip D. Roberts ${ }^{1 *}$ (p.roberts@cabi.org), Hilda Diaz-Soltero ${ }^{2}$ (hdiazsoltero@fs.fed.us), David J. Hemming1 (d.hemming@cabi.org), Martin J. Parr1 (m.parr@cabi.org), Richard H. Shaw ${ }^{3}$ (r.shaw@cabi.org), Nicola Wakefield1 (n.wakefield@cabi.org), Holly J.Wright1 (h.wright@cabi.org), and Arne B.R. Witt ${ }^{4}$ (a.witt@cabi.org).

\begin{abstract}
Background: The Convention on Biological Diversity has reported invasive species as 2 nd greatest cause of species extinction (COP10). However few efforts have been made to collate the evidence to support or contest the impact of invasive species on the decline and/or extinction of threatened species across large taxonomic or geographical scales. This Systematic Review was commissioned by the United States Department for Agriculture (USDA) Invasives Causing Extinction (ICE) programme to determine if the COP10 statement was based on scientific evidence. The evidence needs to be systematically reviewed and mapped to determine the importance and relevance of any such effects in order to develop national and international policies addressing the loss of threatened species, and to prioritise research and mitigation efforts.
\end{abstract}

Methods/design: The searching of online publication databases, grey literature and other resources, such as recovery plans of endangered species, aims to gather existing evidence on whether invasive species are a significant contributor to the decline and/or extinction of threatened species. This study focuses on species under threat in the United States of America (USA). The methods used to carry out the Systematic Review will address the following two fundamental questions: (a) what proportion of threatened species have an invasive species as a significant contributor to their decline?, and (b) through what mechanisms do invasive species contribute towards the decline of native species? The pool of resources gathered has been analysed for relevance and quality using a

\footnotetext{
*Corresponding author

${ }^{1}$ CABI, Nosworthy Way, Wallingford, Oxfordshire, OX10 8DE, United Kingdom

${ }^{2}$ USDA, National Invasive Species Council, 1201 Eye Street, NW., $5^{\text {th }}$ Floor, Washington, DC, USA

${ }^{3} \mathrm{CABI}$, Bakeham Lane, Egham, Surrey, TW209TY, United Kingdom

${ }^{4}$ CABI, ICRAF Complex, United Nations Avenue, Gigiri, P.O. Box 633-00621, Nairobi, Kenya
} 
pre-defined scoring system. A systematic map has been produced, summarising information from individual studies.

Results: This systematic review found broad scientific consensus that invasive species are likely to play a crucial and devastating role in driving species extinctions. The review found that the topic has been vastly understudied. Despite the level of concern raised in the COP10 statement, when considering all US FWS 'threatened species', for only 6.5\% have studies of the impact of invasive species been conducted and published. The reasons for this lack of evidence will be explored subsequently. What is most striking, is that, despite the limited number of studies, where evidence does exist it was overwhelmingly negative. Of all studies that investigated the impact of invasive species on US 'threatened species' $80 \%$ reported a negative impact.

To maximise the practical use of the of this systematic review map the mechanisms of impact were recorded to help provide points of management intervention. The most common mechanisms of impact reported were predation, competition for resources and herbivory.

Conclusions: There is broad scientific consensus that invasive species are likely to play a crucial and devastating role in driving species extinctions. This Systematic Review set out to collect all of the available evidence relating to this claim for US FWS 'threatened species'. This is the first time all evidence has been collated at such a large taxonomic or geographical scale. The review found that the topic has been vastly understudied. Despite the level of concern raised in the COP10 statement, when considering all US FWS 'threatened species', for only $6.5 \%$ have studies of the impact of invasive species been conducted and published. The reasons for this lack of evidence will be explored subsequently. What is most striking, is that, despite the limited number of studies, where evidence does exist it was overwhelmingly negative. Of all studies that investigated the impact of invasive species on US 'threatened species' $80 \%$ (158 cases of evidence) reported a negative impact. This dominance of negative interactions is a clear evidence-based message to policy makers and land managers of the importance of the impact that invasive species are having on already imperilled species.

\section{Keywords}

Invasive species, Alien species, Threatened species, Impact, Decline, Extinction, Mechanism

\section{Definitions}

Invasive species: As defined by the United States of America (USA) Presidential Executive Order 13112 of February 3, 1999 is being used. It states that an "Alien species" means, with respect to a particular ecosystem, any species, including its seeds, eggs, spores, or other biological material capable of propagating that species, that is not native to that ecosystem. It also states that "Invasive species" means an alien species whose introduction does or is likely to cause economic or environmental harm or harm to human health. Harm to animal health has been added to that definition, using the World Organisation for Animal Health (OIE) definitions as to what is meant by "harm".

Threatened species: Species considered by the United States Fish and Wildlife Services (US FWS) as Endangered, Threatened or Candidate species up to date 30 March 2012. 
When 'threatened species' are mentioned in this review, unless specified, it refers to all three levels of species collectively: the endangered of threatened species that have been listed as such under the Endangered Species Act (ESA) on 30 March 2012, the candidate species were, at the time under, consideration for listing by the USFWS under the ESA.

Impact: Any abiotic or biotic influence the presence of an invasive species has on a 'threatened species' either directly or indirectly. This Systematic Review records evidence of all attempts to measure impact and reports the influence of impact as either, negative (harmful in some way), positive (beneficial in some way) or neutral (evidence which tested impact but found no significant impact in either direction).

Case of evidence: When evidence is presented in the Systematic Review it is reported as a case of evidence. This means any time an impact was recorded between an invasive-'threatened species' pair in a unique experiment/observation. More than one unique experiment or observation can come out of a single evidence source (e.g. a peer reviewed paper reporting multiple experiments/observations). It was important to separate out cases of evidence so that the methods associated with each case could be reported alongside the evidence. Using cases of evidence also allowed evidence sources which reported more than one invasive species impacting one or more 'threatened species' within a single source or even experiment/observation.

\section{Background}

There is a broad scientific consensus that invasive species likely play a crucial and devastating role in driving species extinction. At the 2010 Convention on Biological Diversity Conference of Parties (COP10) it was stated that:

"Invasive species are the second biggest driving force of species extinction, after the effects of human activity (habitat loss, overexploitation, and pollution)."

This extinction rate seems likely to accelerate, with additional growth of human populations and activities, furthering climate change, acting as one of the main drivers, may expand the ranges of many invasive species.

However, while there are good ecological reasons for expecting that invasive species are playing a central role in the loss of native species, the scientific evidence to support or contest that idea has not been collected or examined systematically at a national or international level. Even the evidence source behind the COP10 statement has not been presented. For example, within the United States of America (USA), an internal audit of the Species Recovery Plans of endangered or threatened species for IUCN Threatened Species List, undertaken by the United Stated Department for Agriculture (USDA) National Invasive Species Council and US Fish and Wildlife Service (US FWS) in 2010-11, found that the information regarding invasive species that may cause the decline or extinction of 'threatened species' is held in thousands of separate, unobtainable, statements about individual species that are stored in the filing cabinets of site/species experts or in disparate datasets that they manage on local computers, even though a main resource for invasive species policy and evidence is publically available (http://www.invasivespeciesinfo.gov/). Much of the evidence that underpins the Species Recovery Plans is either observational or expert opinions that are not readily accessible to the scientific community, due to lack of reporting in any form of peer-reviewed 
scientific publication. In addition, it is the experience of the review team that within the introductions of published literature the impact to a native species by an invasive, at a particular location, is often inferred, when this is not the focus of that particular paper. These unsubstantiated statements may be used as evidence in state/country/global recovery plans that it is the invasive that is the major causative agent for the decline of the native, when other factors, (i.e. change in grazing regimes/pollution etc.) may in fact be responsible for the native species' decline. Taking these elements together means that it is impossible to determine to what extent invasive species are impacting biodiversity from the current un-reviewed evidence base. It is vital to have an answer to this central question in order to develop national and international polices to address the loss of 'threatened species' due to the negative impact of invasive species, and to prioritise research and mitigation efforts.

Previous efforts to review the evidence have focused on a limited subset of species, such as a single taxonomic group (Kingdom or Order) and have led to contradictions within the peer-reviewed literature. For example, Clavero and García-Berthou's [1] editorial on invasive species causing animal extinctions argued that the use of different methodologies for reporting and sourcing information had led to drastically differing conclusions to whether invasive species caused extinctions to either IUCN Red Listed Threatened Species [2] or those threatened within countries, e.g. North American fish species [3], or mammals on Australian islands [4]. This study aims to systematically map the evidence for all US 'threatened species' on the US FWS list and the candidate species awaiting listing, that are being impacted by an invasive species, and by what mechanism this impact occurs. Under the US ESA, "endangered" means "any species which is in danger of extinction throughout all or a significant portion of its range", while "threatened" is defined as "any species which is likely to become an endangered species within the foreseeable future throughout all or a significant portion of its range". Candidate species are under consideration for threatened or endangered status. This Systematic Review considers all US FWS listed 'threatened species', which were listed or under consideration on 30 March 2012. The study is focused on species for the USA because scoping work indicated that the full IUCN list of 3,947 critically endangered species would require more resources than were available. The US FWS list includes $65 \%$ of the species on the IUCN CR list for the USA. The evidence in the literature from all taxa was included, but there was no attempt to balance numbers from different taxa.

In 2010 the USDA started the Invasives Causing Extinction (ICE) programme. The programme needed to verify that it was based on science. Thus ICE commissioned this Systematic Review.

The output of this study will allow the USDA to assess the validity of the scientific underpinnings of its ICE programme. Results will indicate additional resource needs on the impact of invasive species on 'threatened species' in the USA. In addition, the evidence will be used to inform land managers on which invasive species should be controlled to reduce their impact on 'threatened species'.

\section{Objective of the review}

The primary review question: "What is the evidence that invasive species are a significant contributor to the decline or loss of US 'threatened species'?" 
To answer this main question, a group of stakeholders, at the request of the USDA, took part in a two-day meeting in January 2011 in Georgetown, Washington D.C., USA, to discuss invasive species and their impact on 'threatened species' in the USA. The stakeholder group consisted of the USDA, The Conservation Breeding Specialist Group (CBSG) of IUCN, US FWS, the National Marine Fisheries Service (NMFS) and the review team from CABI. The group was selected to represent US stakeholders (USDA and NMFS), international conservation agencies (CBSG) and an independent science organisation with a specialist focus on the management of invasive species (CABI). Despite their different perspectives, all stakeholders were in agreement that in order to answer such a broad question, two additional questions would have to be asked (see Table 1) that would capture an impact (or any measure of change) to the threatened species and also the mechanisms by which the invasive species causes that impact.

Secondary question 1: "What proportion of 'threatened species' have an invasive species as a significant contributor to their decline?"

For this secondary question (and indeed all instances were 'threatened species' are mentioned in this review" it refers to species considered by the United States Fish and Wildlife Services (US FWS) as Endangered, Threatened or Candidate species up to date 30 March 2012.

When 'threatened species' are mentioned in this review, unless specified, it refers to all three levels of species collectively: the endangered of threatened species that have been listed as such under the Endangered Species Act (ESA) on 30 March 2012, the candidate species were, at the time under, consideration for listing by the USFWS under the ESA.

This will include an analysis of the threats facing 'threatened species'. The analysis will map all evidence relating to both the invasive species and the 'threatened species', effectively coming up with species pairs (for each specific invasive species and its relevant 'threatened species'), and the impact of the invasive species. From these individual pairs, an overall proportion of impact will be calculated.

Secondary question 2: "Through what mechanisms do invasive species contribute towards the decline of native species?"

This question will identify the mechanisms by which each of the invasive species identified in the previous question impact the native species. All the data relating to mechanisms presented in the evidence selected will be captured through the process and summarised under relevant mechanistic categories. In addition, the review team will also highlight all the different impact scales that are available to managers and policy makers.

The essence of this approach uses the conventional, Systematic Review, population, exposure, comparator, outcome (PECO), structure: where the population is the native 'threatened species', the exposure is the introduction or presence of the population of the invasive species, the comparator is a measure within the study design, such as the population before the arrival of the invasive species, or a comparable population not exposed to the invasive species, and the outcome is the change in the population of the native 'threatened species' (this may include change in distribution, abundance, density or other dynamics). 


\section{Methods}

\section{Searches}

The list of search terms used in the review is listed in the Appendix 1. The most effective search strategy was developed through small-scale scoping trials, using some of the species about which greatest concern has been raised. The searches used Boolean logic to combine extensive lists all of the 'threatened species' with search terms around invasive species and impact to find all the relevant material. The following sources were search for evidence using the refined search string.

1. The following general electronic databases were searched:

a) $\mathrm{CAB}$ Abstracts (through $\mathrm{CAB}$ Direct)

b) Web of Knowledge

c) British Library Direct

d) Science Direct

e) Directory of Open-Access Journals

f) COPAC

g) Scirus (All journal sources)

h) Scopus

i) Agricola

j) Centre for Ecology and Hydrology online database

k) JSTOR

I) ConservationEvidence.com

m) WorldWideScience.org

n) Wildlife and Ecology Studies Worldwide

o) The US Endangered and Threatened Species Recovery Plans were also consulted in detail. These are USA-specific plans that were known to contain references to invasive species in relation to the threatened species in question. Further references were obtained from The Smithsonian's Biological Conservation Newsletter and from four reports (March, June, September and December 2011) by Dr Jan Eldridge (who searched Nature serve and the US FWS's website) on invasive species threatening endangered, threatened and candidate species for the CBSG.

2. Other specific/specialised databases were searched, e.g.:

a) CABI's Invasive Species Compendium 

b) IUCN Red List of Threatened Species data
c) US Fish and Wildlife Service
d) USDA National Invasive Species Information Centre

3. The following resources were examined for relevant information on invasive species:
a) Nonindigenous Aquatic Species
b) Global Invasive Species Database
c) Pacific Island Ecosystems at Risk (PIER)
d) These sources are the basis of the lists of invasive species and 'threatened species' considered and against which evidence was actively sought for this Systematic Review. Use of specialised databases that require name-specific searches was limited. The emphasis was on a representative, repeatable and unbiased approach that allowed the clearest possible answer to the secondary question.

4. Hand searching/paging of key titles was undertaken, e.g.:
a) Aliens, a publication by IUCN

5. Experts contacted: Recognised experts, practitioners and authors of recent publications were contacted to see if any relevant unpublished material or datasets were available for inclusion within the review.

6. In addition, web searches were performed using the search engines:

a) Google Scholar

b) Microsoft Academic Search and Google (organic).

c) The first 50 hits (.doc(x)/.txt/.xls/.pdf files, using advanced search) from each data source were examined for appropriate evidence. No further links from the captured website were followed unless linked to a .doc/.pdf file.

d) Email lists were joined: CABI's Invasive Alien Species List, Science Daily and The IUCN Aliens List to ensure relevant references published following the initial literature search would be incorporated into the study. All emerging new literature was logged in a separate EndNote library to allow for transparency of when and how all references entered the Systematic Review process.

Each search was stored in a separate EndNote Library, for record keeping and then combined into a "Total searches library SQx (including duplications)". Two de-duplication processes were undertaken, firstly using EndNote, then a second manual scan to remove duplicates with differing syntax (e.g. ' 2 ' or ' $\mathrm{Il}$ '). This deduplication process created the first EndNote Library that was considered for application of the study inclusion criteria at the title and abstract level. 


\section{Study inclusion criteria}

The inclusion and exclusion criteria were applied by one reviewer to all potential studies at the title and abstract level. Where there was insufficient information to make an informed decision regarding a study's inclusion, then relevance to the next stage of the review process (full text assessment) was assumed. A second reviewer examined a random subset of at least $25 \%$ of the reference list (up to a maximum of 2,500 references) to assess repeatability of the selection criteria. Kappa analysis was performed, with a rating of 0.61 or above being required to pass the assessment. Disagreement regarding inclusion/exclusion of studies was resolved by consensus, or following an assessment by a third reviewer.

Inclusion and exclusion criteria for both secondary questions followed the normal systematic convention of a PECO structure. The PECO structure for secondary question one and two is shown in tables 1 and 2 respectively and summarised together in table 3 .

\section{Table 1:}

PECO structure for secondary question 1 "What proportion of 'threatened species' have an invasive species as a significant contributor to their decline?" studies were assessed against the following inclusion/exclusion criteria.

\begin{tabular}{|ll|}
\multicolumn{1}{|c|}{ PECO } & \multicolumn{1}{c|}{ Inclusion/Exclusion criteria } \\
Population & $\begin{array}{l}\text { All studies that investigated one or more species included on the US FWS list as } \\
\text { Endangered, Threatened or Candidate species list (as of } 30 \text { March 2012). These are } \\
\text { listed in Appendix 1. }\end{array}$ \\
\hline Exposure & $\begin{array}{l}\text { Any invasive species having a documented impact (positive, negative or lack of) on } \\
\text { the threatened species. }\end{array}$ \\
\hline Comparator(s) & $\begin{array}{l}\text { N/A (although for inclusion in the analysis a comparator of no invasive species or a } \\
\text { time series will be required). }\end{array}$ \\
\hline Study Design & $\begin{array}{l}\text { All study designs included in the review. The quality of the original methodology for } \\
\text { each study was assessed and summarised in the final report. }\end{array}$ \\
\hline
\end{tabular}

\section{Table 2:}

PECO structure for secondary question 2, "Through what mechanisms do invasive alien species contribute towards the decline of native species?" studies were assessed against the following inclusion/exclusion criteria.

\begin{tabular}{|ll|}
\hline \multicolumn{1}{|c|}{ PECO } & \multicolumn{1}{c|}{ Inclusion/Exclusion criteria } \\
Population & Any invasive species that has been identified under secondary question 1. \\
\hline Exposure & $\begin{array}{l}\text { The invasive species has had an impact on a threatened species under secondary } \\
\text { question 1. }\end{array}$ \\
\hline Comparator(s) & N/A \\
\hline Study Design & All study designs will be accepted into the review. \\
\hline Focus of & Study must mention one or more mechanisms by which the invasive species \\
\hline
\end{tabular}




\section{Table 3:}

Components of the Systematic Review secondary questions (SQ)

\begin{tabular}{|c|c|c|c|c|}
\hline & Population & $\begin{array}{l}\text { Intervention/ } \\
\text { exposure }\end{array}$ & $\begin{array}{l}\text { Comparator/study } \\
\text { design/evidence } \\
\text { type }\end{array}$ & Outcome \\
\hline $\begin{array}{l}\text { SQ1 “What proportion of } \\
\text { 'threatened species' } \\
\text { have an invasive species } \\
\text { as a significant } \\
\text { contributor to their } \\
\text { decline?” }\end{array}$ & $\begin{array}{l}\text { 'threatened } \\
\text { species': } \\
\text { US FWS } \\
\text { endangered, } \\
\text { threatened and } \\
\text { candidate } \\
\text { species }\end{array}$ & $\begin{array}{l}\text { Invasive } \\
\text { species }\end{array}$ & $\begin{array}{l}\text { Without invasive } \\
\text { species, } \\
\text { randomised block } \\
\text { design } \\
\text { time series (before } \\
\text { and after), } \\
\text { Site comparison } \\
\text { (comparing } \\
\text { exposure to non- } \\
\text { exposure on } \\
\text { adjacent sites), } \\
\text { Observations }\end{array}$ & $\begin{array}{l}\text { Change in status } \\
\text { of the } \\
\text { 'threatened } \\
\text { species' } \\
\text { population size } \\
\text { (size/range/den } \\
\text { sity/fecundity } \\
\text { etc.) }\end{array}$ \\
\hline $\begin{array}{l}\text { SQ2 "Through what } \\
\text { mechanisms do invasive } \\
\text { alien species contribute } \\
\text { towards the decline of } \\
\text { native species?" }\end{array}$ & Invasive species & $\begin{array}{l}\text { Threatened } \\
\text { species: } \\
\text { US FWS } \\
\text { endangered, } \\
\text { threatened or } \\
\text { candidate } \\
\text { species }\end{array}$ & $\begin{array}{l}\text { Biological papers, } \\
\text { laboratory studies, } \\
\text { genetic studies }\end{array}$ & $\begin{array}{l}\text { Mechanism of } \\
\text { impact }\end{array}$ \\
\hline
\end{tabular}

\section{Exclusion for both sub questions}

1. Owing to the time constraints of the review, only English language documents were included within the final synthesis. Any non-English documents were identified in a separate EndNote library, which will be made available to future review teams.

2. Human pathogens are excluded from this review as an invasive species type.

For this Systematic Review Map, the focus was on invasive species whose establishment and spread threatens a species [6]. For inclusion into the review, there needed to be a documented impact to a 'threatened species' that the USA. 


\section{Potential effect modifiers and reasons for heterogeneity}

Where information regarding the reasons for heterogeneity were presented in the original studies, it was recorded, and when possible assessed. Sources of heterogeneity within the studies may be one (or more) of the following: study design, habitat type/degradation or alteration, geographical region within USA, species taxon, life-history strategy of either species or trophic level.

\section{Study quality assessment}

The review team assessed the study methodologies reported in all articles accepted at the full text level. The study quality is scored according to a hierarchy of evidence adapted from Systematic Review guidelines used in medicine and public health [7] and conservation [8]; e.g. a randomised control trial was weighed higher than a site comparison study (see Appendix 2 for the draft coding tool). The results (total score) of the study quality assessments are presented in the summary tables within the appendix, for full transparency.

\section{Data extraction strategy}

Data was extracted, and a random subset of at least $25 \%$ of the selected studies was reviewed to verify repeatability and accuracy. The electronic data extraction form was trialled and checked with the stakeholders at the Georgetown meeting and amended based on their feedback. All data extracted is presented in summary tables in the appendix (appendix 3 and 4 ) of this full review document.

For secondary question 1 (proportion of 'threatened species' impacted upon), data regarding the study characteristics (e.g. location), research methodologies (e.g. timeline and sample size), the threatened species, invasive species (and whether the invasive species population increased during the study), and the impact were recorded.

For secondary question $\mathbf{2}$ (mechanisms of impact), data relating to the mechanism by which impact was brought about was extracted.

\section{Data synthesis and presentation}

Data from all accepted studies was extracted and has been presented as a data map within the summary tables (appendix 3 and 4 ) of this report. The map follows the format of a clear and reusable spreadsheet, summarising study characteristics, study quality and results. Data visualisations of this systematic map of the evidence have been prepared to facilitate ease of analysis (Appendix 5).

In the original protocol [9], quantitative analysis was planned to be undertaken on any data that was suitable for formal statistical analysis. Where possible, meta-analyses for each of the interventions were to be undertaken, with the reasons for heterogeneity assessed by meta-regression (univariate or multivariate). Subset analysis was also planned if there was sufficient data on taxonomic groups or specific habitats (highlighting across-species heterogeneity). If possible, data was to be captured across multiple isolated populations (e.g. mountain tops) that might have allowed for within-species heterogeneity to be investigated. It was clear from early in the data extraction process that this was not going to be possible and therefore the systematic map summarising all evidence and signposting back to originally studies was established as the primary objective of the review team. 
Species pairs ('threatened species' and invasive) were extracted from each of the sources which met the full acceptance criteria for inclusion. These species pairs allow both impact and competition mechanism to be categorised against them, to produce an overall systematic visualisation of the status of invasive/'threatened species' relationships.

\section{Results}

\section{Search results}

The above search strategy, initiated on 10 March 2012 and completed on 30 May 2012, retrieved a total of 22,478 references which were entered into a single Endnote Library. Duplicates within this combined reference library were identified in two ways: 1 . Electronically identified using the auto de-duplification function in Endnote and then 2. Manually, sorting references alphabetically and, screening them by eye. This second manual screening ensured that any duplicates using different syntax (e.g. ' 2 ' or 'II') were identified and removed. Following the de-duplification process two new Endnote Libraries were formed: 1 . A copy of the total searches library with duplicates removed $(12,968$ references), and 2 . a record of all duplicates removed (9,511 references).

The 12,968 unique references were next screened at the title and abstract level. References were excluded from the study if it was absolutely clear from the title and abstract that 1 . the population criteria was not met, i.e. the study did not refer to any US FWS 'threatened species', 2 . the exposure criteria was not met, i.e. the reference did not document an invasive species impacting the 'threatened species' and finally, 3. references were not in English. All excluded papers were recorded in a separate "not relevant" endnote library (10,909 references). An Endnote library of all papers which were not in English was made so that these could be accessed in the future and added to the Systematic Review Map should further funds arise of an external organisation/person wish to access them. No references were excluded as a result of the study design used or the lack of a comparator. Where it was not absolutely clear at the title and abstract level if the inclusion criteria were satisfied, references remained in the study for closer analysis at the full text level. These studies were recorded together with those which did meet the inclusion criteria in a new Endnote library "Studies retrieved for more detailed evaluation at full text level" (2059 references)

All levels of agreement between the review team were calculated using Kappa analysis. This was calculated to be 0.8 for the inclusion of studies at full text to the final review, and for data extraction was 0.76. All disagreements between the review team members (P.D. Roberts, D.J. Hemming and H. Wright) were discussed and a decision agreed upon.

\section{Scope}

1. Geographical scope of the results: The study scope considered the impact of invasive species on all US FWS 'threatened species'. There was however no restriction on geographical location of the study. If a reference documented a US 'threatened species' being impacted by a threatened species it was included irrespective of the country the US listed 'threatened species' was present in. As such references from Ecuador (10), Puerto Rico (3), Canada (2), Australia (1), Barbados (1), Brazil (1) and New Caledonia (1) were included (table 4). This review acts as a central repository of all data of invasive species impacting on US 'threatened species' (which meet the criteria of the review set out on the methods) no matter where they occur. For other countries this Systematic Review Map acts as a starting point but is in no way an exhaustive summary of 
evidence for invasive species causing extinction in those countries. Such data is important to collect in further studies and will be discussed in the discussion section but is outside the scope of the present review.

Geographic location data, down to state level, of the observations/experiments were extracted and are reported alongside the other evidence in Appendix 3 and 4. The majority of cases of invasive species, impacting on 'threatened species' are from island locations, such as Hawaii (67), Galapagos Islands (10) and Puerto Rico (4). In addition, some of the cases reported from California come from islands within the states of California.

\section{Table 4:}

A summary of the geographic locations from which evidence has been found of invasive species impacting on US FWS "threatened species.

\begin{tabular}{|cccc|}
\hline State/Region & No. of cases & State/Region & No. of cases \\
\hline Hawaii & 67 & New Mexico & 2 \\
\hline California & 42 & Oregon & 2 \\
\hline Arizona & 15 & Alberta & 1 \\
\hline Michigan & 11 & Bahia & 1 \\
\hline Galapagos Islands & 10 & Guam & 1 \\
\hline Florida & 6 & New Jersey & 1 \\
\hline Nevada & 4 & Quebec & 1 \\
\hline Puerto Rico & 4 & Rocky Mountains & 1 \\
\hline Georgia & 3 & Surprise Island & 1 \\
\hline Montana & 3 & Texas & 1 \\
\hline Utah & 3 & Wyoming & 1 \\
\hline Nebraska & 2 & & \\
\hline
\end{tabular}

2. Habitat scope of the results: The majority of cases where invasive species were impacting on US FWS 'threatened species' were found to be in natural or semi-natural terrestrial habitats, with the fewest cases in the marine environment (Table 5).

\section{Table 5:}

A summary of the habitats where invasive species are impacting on US FWS 'threatened species'. These categories match those within the species datasheets available in the Invasive Species Compendium (www.cabi.org/isc).

\begin{tabular}{|c|c|}
\hline Habitat & No. of cases of evidence \\
\hline Terrestrial natural or semi-natural & 71 \\
\hline Freshwater & 45 \\
\hline Littoral & 28 \\
\hline Terrestrial managed & 23 \\
\hline Brackish & 10 \\
\hline Marine & 3 \\
\hline
\end{tabular}

3. Taxonomic scope of the results: All invasive species and all US FWS 'threatened species' were included in the Systematic Review irrespective of taxonomic group. This was done in order to capture the full magnitude of evidence of invasive species impacting 'threatened species'. 
The most common records of taxa of invasive species impacting on 'threatened species' were mammals (50), plants (37), fish (30) and molluscs (21) with only single records of the impacts of protozoa, reptiles, viruses and worms (Figure 1.

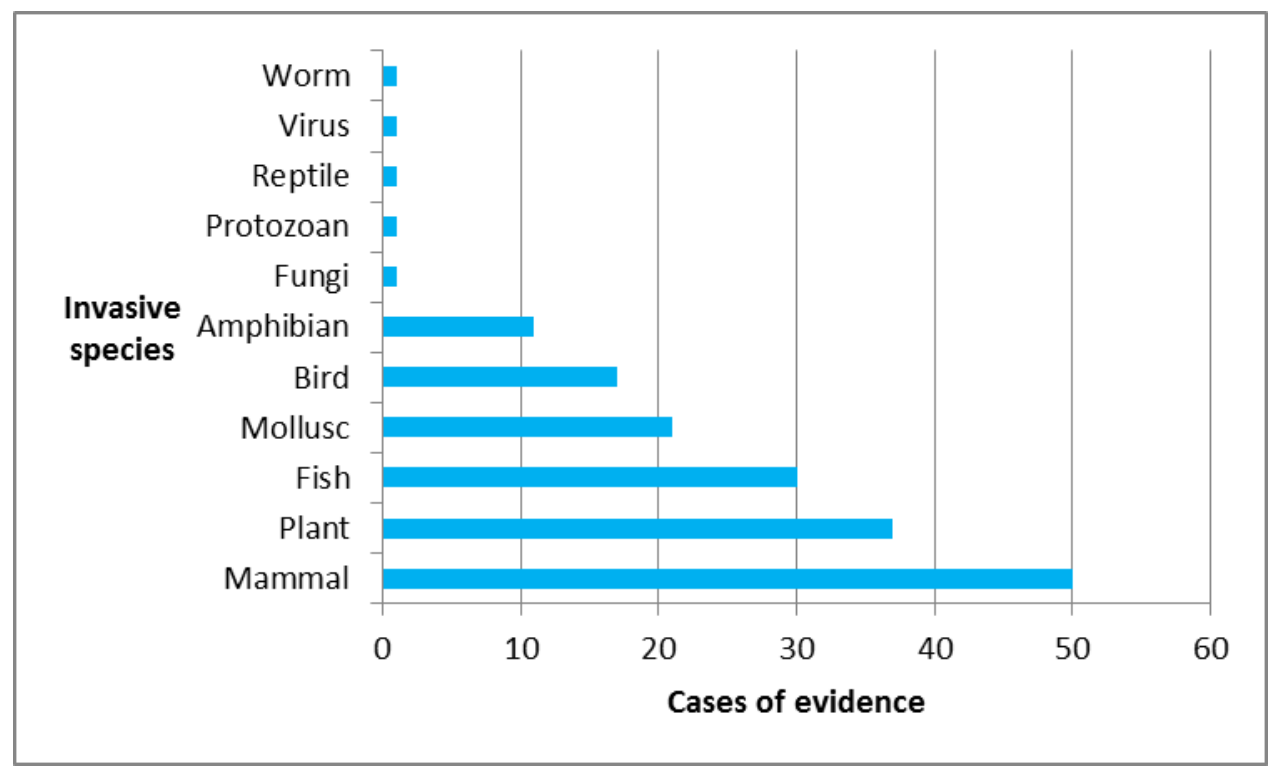

Figure 1: The taxonomic class of invasive species impacting US FWS 'threatened species' for which data was found.

The most common records of taxonomic groups of US FWS 'threatened species' impacted upon by invasive species were plants (60), birds (58) and fish (30) (figure 2). Insects (7 cases) and molluscs ( 6 cases) were the least reported. No evidence of lower taxonomic groups were found to be impacted by invasive species.

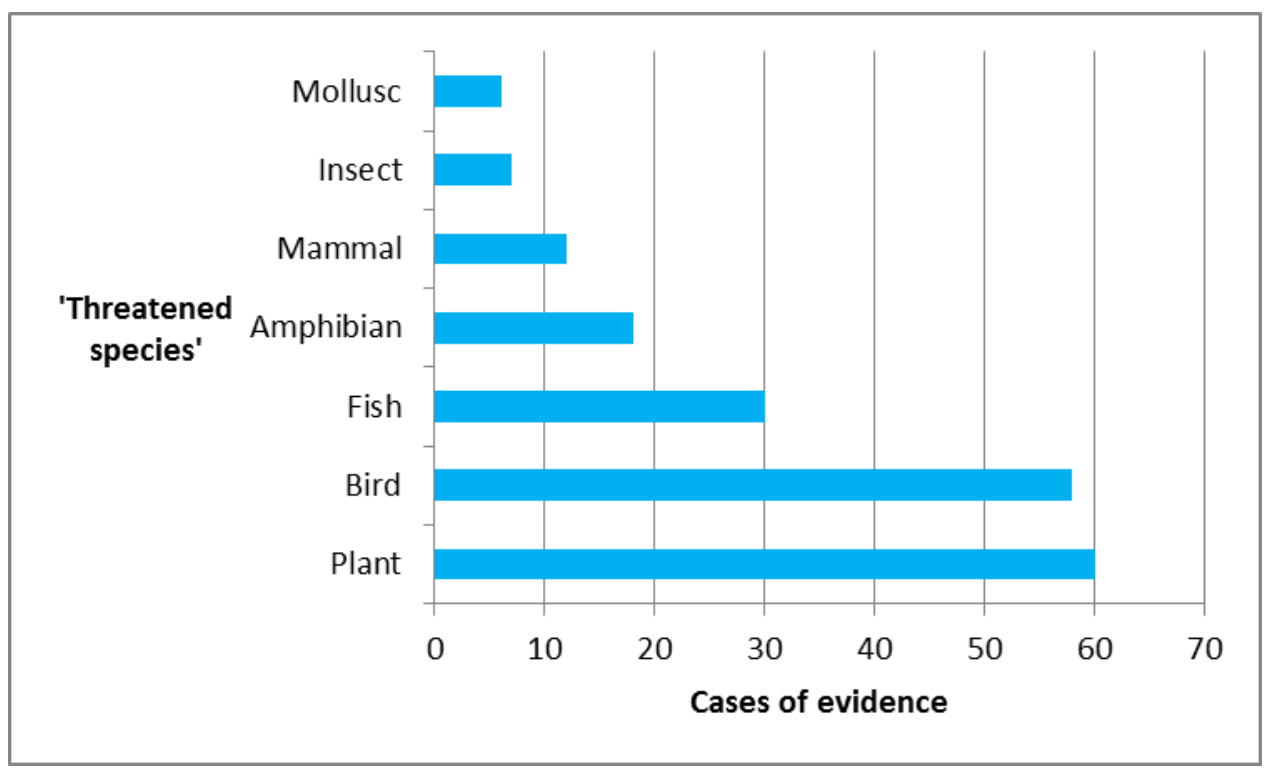

Figure 2: The taxonomic class of invasive species impacting US FWS listed species for which data was found. 


\section{Quality of the data}

Understandably, when a land manager observes that an invasive species has invaded a habitat alongside a 'threatened species', the priority is to protect that 'threatened species' and to remove the invasive species rather than to design and conduct a scientifically rigorous impact study of whether the invading species is having an impact (positive, negative or neutral) to the 'threatened species'. As a result, the scientific data that does exist is largely from observational data (43\%) and time-series (24\%) data based on correlation and opportunistic "natural experiments" (figure 6). The quality of the data was not very high: nearly no quantitative evidence of impact was reported; effect modifiers and counterfactuals where often lacking or mentioned but not quantified. No invasive'threatened species' pair occurs in an ecosystem in isolation, and it is hard to quantify the size of the effect of the invasive on the 'threatened species' without careful recording of various abiotic and biotic effect modifiers within the system and by having a proper control trial. Without accurate calculations of the size of effect it is not appropriate to conduct meta-analysis on the results. However, while meta-analysis is not possible, the evidence collected does allow us to answer the main research question and its sub-questions of this Systematic Review and presented in the discussion.

\section{Table 6:}

Study design and the number of cases of evidence

\begin{tabular}{|lc|}
\multicolumn{1}{|c|}{ Study design } & No. of cases \\
\hline Observation Experimental & 48 \\
\hline Observation & 38 \\
\hline Interrupted time-series & 24 \\
\hline Time Series & 23 \\
\hline Randomised control trial & 22 \\
\hline Before after control intervention & 14 \\
\hline Site comparison & 14 \\
\hline Randomised control trial ex-situ & 10 \\
\hline Control intervention & 3 \\
\hline Historical control trial & 2 \\
\hline
\end{tabular}

\section{Reasons for heterogeneity}

While undertaking the data extraction, the team also recorded potential reasons for heterogeneity from each of the papers. This was originally to be used to explain reasons for heterogeneity in the formal meta-analysis and to group evidence in smaller focused analysis around habitats and geographical spread (as well as islands/mainland). Since the data for formal meta-analysis was not available the following summary tables (Appendix 3 and 4 ) show these characteristics.

\section{Results secondary questions 1}

"What proportion of 'threatened species' have an invasive species as a significant contributor to their decline?"

Data was extracted from 101 sources which met all of the inclusion criteria for secondary questions whereby the study population was a US FWS 'threatened species' (see Appendix 6) and the source documented evidence of an invasive species having an impact on that 'threatened species'. 
Within those 101 papers, 199 cases of evidence were found of an invasive species impacting (negative, neutral or positive) on a US FWS 'threatened species', allowing for 165 unique invasive'threatened species' pairs to be identified. This consisted of 95 unique invasive species, impacting 107 unique US FWS 'threatened species'. The majority of evidence (75\%) shows that invasive species impact the most at risk group of FWS listed species- those that are endangered rather than those that are classified as threatened or candidate species under the ESA (Table 7).

\section{Table 7:}

The number of cases for which evidence was found for invasive species impacting US FWS 'threatened species' by endangered/threatened/candidate status of the native species as set by the US ESA.

\begin{tabular}{|lc|}
\hline Level of status in the ESA of 'threatened species' & No. cases \\
\hline Endangered & 150 \\
\hline Threatened & 32 \\
\hline Candidate & 17 \\
\hline
\end{tabular}

When considered as a proportion of the total number of all US FWS 'threatened species' as of 30 March 2012, it was discovered that only $6.5 \%$ of these all US FWS listed species had evidence of an invasive species having an impact.

The search strategy of this Systematic Review was carefully designed to collate all evidence on the impact of invasive species, be that evidence reporting a negative, natural or positive impact. By having an open search strategy the review team discovered that $80 \%$ of cases reported the impact of an invasive species to be negative on the 'threatened species', $18 \%$ of cases of evidence reported neutral impact and only $2 \%$ of evidence ( 5 cases of evidence) found invasive species to have a positive impact on US FWS 'threatened species'. 


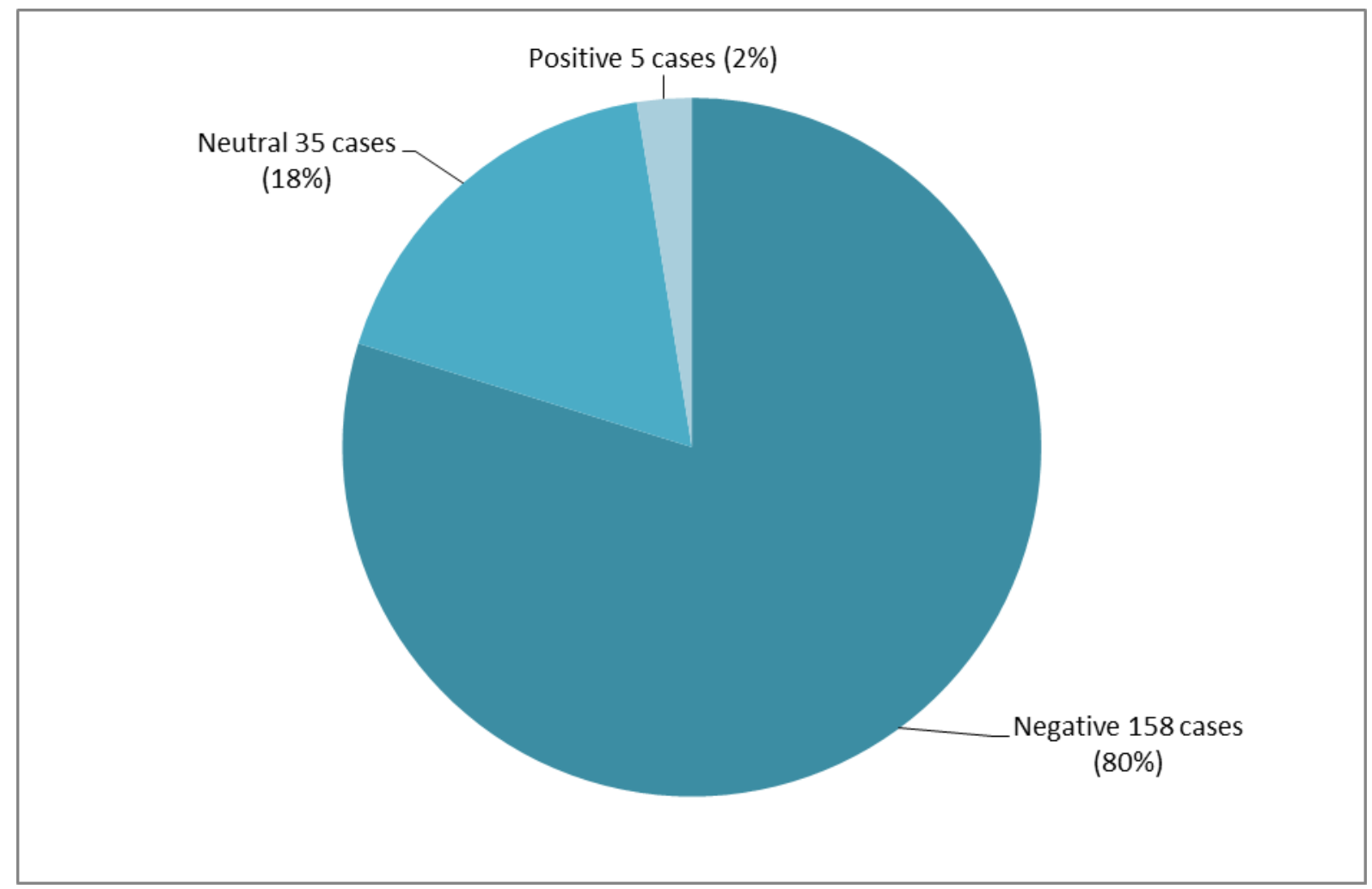

Figure 3: Impact of invasive species on the US FWS 'threatened species'.

ference to the original source is presented in Appendices section. For an alphabetic breakdown of the evidence by the invasive species causing impact is in Appendix 3. The same data ordered alphabetically by the US FWS 'threatened species' is presented in Appendix 4. The full list of references that were included in this review and had evidence extracted from are listed in Appendix 6.

\section{Table 8:}

A summary of taxonomic species pairs, invasive impacting US FWS 'threatened species', sorted by number of cases of evidence.

\begin{tabular}{|ccc|}
\hline Invasive species & US FWS 'threatened species' & No. of cases \\
\hline Mammal & Bird & 27 \\
\hline Fish & Fish & 23 \\
\hline Insect & Plant & 19 \\
\hline Plant & Plant & 17 \\
\hline Mammal & Plant & 13 \\
\hline Plant & Bird & 12 \\
\hline Bird & Bird & 11 \\
\hline Amphibian & Amphibian & 10 \\
\hline Mollusc & Plant & 9 \\
\hline Fish & Amphibian & 7 \\
\hline Mollusc & Mollusc & 6 \\
\hline Insect & Bird & 5 \\
\hline Mammal & Mammal & 5 \\
\hline Mammal & Reptile & 5 \\
\hline Bird & Mammal & 4 \\
\hline Mollusc & Fish & 4 \\
\hline
\end{tabular}




\begin{tabular}{|ccc|}
\hline Plant & Insect & 4 \\
\hline Insect & Insect & 3 \\
\hline Mollusc & Bird & 2 \\
\hline Plant & Fish & 2 \\
\hline Plant & Reptile & 2 \\
\hline Amphibian & Fish & 1 \\
\hline Bird & Plant & 1 \\
\hline Fungi & Plant & 1 \\
\hline Insect & Reptile & 1 \\
\hline Protozoan & Mammal & 1 \\
\hline Reptile & Bird & 1 \\
\hline Virus & Mammal & 1 \\
\hline Worm & Mammal & 1 \\
\hline Bird & Amphibian & 1 \\
\hline
\end{tabular}

The data presented in Table 8 gives a summary of the taxonomic groups of the species pairs. The detailed data for the individual species are presented in the tables in the Appendices. Mammals have the greatest impact on 'threatened species', while plants are the most impacted by invasive species from the studies captured in this review.

\section{Results secondary question 2}

"Through what mechanisms do invasive species contribute to the decline of native species?"

For all documents that contained evidence of an invasive species impacting a US FWS 'threatened species' (i.e. met the full inclusion criteria of secondary questions 1 ) the references were also fully screened for secondary question 2 and where any mention of the mechanism of impact was document this information was extracted.

According to the reviewed literature invasive species mainly contributed to a decline in US FWS 'threatened species' through competition (monopolising resources), predation and hervbivory (Table 8).

\section{Table 8:}

Summary of the mechanisms used by the invasive species to impact the US FWS "threatened species.

\begin{tabular}{|lc|}
\multicolumn{1}{c}{ Mechanism } & No. of cases \\
\hline Competition monopolising resources & 50 \\
\hline Predation & 47 \\
\hline Herbivory or grazing or browsing & 30 \\
\hline Behavioural disruption & 24 \\
\hline Unknown & 21 \\
\hline Altered food web & 7 \\
\hline Parasitism & 6 \\
\hline Ecosystem change or habitat alteration & 4 \\
\hline Interaction with mutualisms & 4 \\
\hline Hybridisation & 2 \\
\hline Rooting or digging & 2 \\
\hline
\end{tabular}




\begin{tabular}{|ll|}
\hline Competition shading & 1 \\
\hline Interaction with other invasive species & 1 \\
\hline
\end{tabular}

\section{Discussion}

It is important for policy makers to know what evidence underpins the COP10 statement regarding invasive species causing extinction so that so that advocacy for action to address invasive species problems can be fully justified. For USDA verifying the scientific underpinnings of the COP10 statement will give justification to their ICE programme. It would have been short-sighted of this Systematic Review to stop there. Policy makers need to know what actions to take: their budget and resources will always be finite, and their actions should also be prioritised in relation to the scientific evidence. It was for this reason that this Systematic Review addressed the topic of evidence behind the COP10 statement through its two sub-questions. The first sub-question sought not only to answer how many 'threatened species' have an invasive species contributing to their decline, but also to map out species pairs of impact so that priorities can be set on which invasive species to control and which 'threatened species' need particular attention. Further still, once these species priorities are set, decisions still need to be made on what to do about problems. It is often not possible to completely eradicate an invasive species from an ecosystem, therefore, it is important to limit, as much as possible, the impact that is having on the threatened species. By capturing the information on the mechanisms of impact, species-specific points of intervention can be identified, and used to prevent further decline and enhance restoration of the threatened species.

\section{Discussion secondary question 1}

"What proportion of 'threatened species' have an invasive species as a significant contributor to their decline?"

\section{The evidence is overwhelmingly negative}

As noted earlier, there is broad scientific consensus that invasive species are likely to play a crucial and devastating role in driving species extinctions. This Systematic Review set out to collect all of the available evidence relating to this claim for US FWS 'threatened species'. This is the first time all evidence has been collated at such a large taxonomic or geographical scale. The review found that the topic has been vastly understudied. Despite the level of concern raised in the COP10 statement, when considering all US FWS 'threatened species', for only $6.5 \%$ have studies of the impact of invasive species been conducted and published. The reasons for this lack of evidence will be explored subsequently. What is most striking, is that, despite the limited number of studies, where evidence does exist it was overwhelmingly negative. Of all studies that investigated the impact of invasive species on US 'threatened species' $80 \%$ (158 cases of evidence) reported a negative impact. This dominance of negative interactions is a clear evidence-based message to policy makers and land managers of the importance of the impact that invasive species are having on already imperilled species.

\section{Reasons why the issue has been under-studied}

Understandably, when there are reasonable grounds to suspect an invasive species is impacting a threatened species the priority is to control the invasive and protect the 'threatened species' before it is too late, rather than to design a scientific study, monitor the impact and publish the results. It is therefore not surprising that the impact of invasive species has only been studied for $6.5 \%$ of all US 
FWS 'threatened species'. While this makes the research question harder to answer, it does not make the question any less valid. Policy makers and land managers need to allocate limited resources and make control/protection decisions. These decisions need to be based on the best available evidence. This review collates together this evidence and provides a powerful resource to help set priorities. Despite the small number of 'threatened species' studied, the high proportion of negative impacts is persuasive that the evidence we do have must be used to set priorities to prevent new invasive arrivals, control existing invasive species and protect 'threatened species'.

\section{The evidence found is likely an underestimation of the true impact}

1. Most studies only look at individual impacts and mechanisms: As outlined, there are practical and ethical issues to measure the impact of invasive species when the subject is a 'threatened species'. As such, the majority of studies identified used observation or time series/natural experiment methods. These scientific methods lack the scientific control to fully understand the complex impact a new introduction has within an ecosystem. Therefore, it is, highly likely that complex interactions will be overlooked (i.e. invasive species impacting multiple native species, impacts through intermediary species or impacts via multiple mechanisms). These interactions would only be captured in very carefully designed and controlled ecosystem level studies. The intrinsic difficulties and costs in setting up such studies in this field make it highly likely that the true scale of the impact has been underestimated.

2. Positive and neutral results should be viewed with caution: As stated $80 \%$ of all of the evidence identified on the impact of invasive species on 'threatened species' found the impact to be negative. There are a number of reasons to believe that this result may be an underestimate. Firstly when considering the natural impact results, there were a number of studies that were carefully designed but missed the strict $95 \%$ certainty standard of significance. It was likely that for a number of studies this benchmark was missed not because the impact was not occurring but because the sample size was small - something understandable when the subject is an already 'threatened species'.

\section{Discussion secondary question 2}

"Through what mechanisms do invasive species contribute towards the decline of native species?"

\section{The importance of understanding impact mechanisms}

If management practices are to be based on evidence it is essential to understand the mechanisms through which invasive species impact 'threatened species'. Understanding these mechanisms allows appropriate and practical points of management intervention to be identified. It is often not possible or cost-effective to completely eradicate an invasive species, but better to attempt to mitigate the deleterious impact it is having - especially a 'threatened species'. In light of this, wherever a study reported the mechanism of impact this was captured and is presented alongside the evidence. This allows land managers and policy makers to use the appendix to set priorities regarding which invasive species they should be controlling (appendix 3 ) or which 'threatened species' they should be attempting to protect (appendix 4), while at the same time understanding how those species are impacting/being impacted. For instance, if an invasive weed is shading out a rare plant and it is not possible to completely remove the invasive, then cutting it back with a regular 
trimming regime might be enough to prevent the loss of the rare plant. Awareness of the impact mechanism can guide the specific management approach.

\section{The primary review question is: "What is the evidence that invasive species are a significant contributor to the decline or loss of US 'threatened species'?"}

The key finding of this Systematic Review is that where the issue has been studied, the impact of invasive species on US 'threatened species' is overwhelmingly negative. For a number of reasons, which have been explored, the topic has been understudied. However, where it has been studied the majority of evidence shows invasive species contribute to the decline of 'threatened species', and furthermore, this negative impact is likely to be an underestimation. These findings give clear evidence-based grounds to raise programmes associated with reducing extinction caused by invasive species higher up the political agenda. By collating evidence over such a broad taxonomic and geographic range, for the first time the broad picture is seen. Negative impacts are not just occurring between isolated species pairs or in unique ecological regions but are the overall trend across space, time and taxa. The evidence lends itself well to a precautionary principle approach. While only a small fraction of the full body of evidence has been collected, action should be taken based on what we do know: that invasive species are significantly contributing the decline of threatened species.

\section{Review limitations}

\section{Scope limitations}

1. Threatened species considered: This review presents a collation of evidence on the impact of invasive species causing extinction for all US FWS 'threatened species' up to 30th May 2012. To our knowledge this is the largest collation of evidence on this topic in terms of both taxonomic and geographical scope. However it is not exhaustive. As with any project, its goals have to be achieved, within the time and resources available. Searching for evidence using the US FWS 'threatened species' brought up 13,000 papers to be manually screened. To undertake a wider study, i.e. to have included marine species in the USA or to have searched for the full IUCN list of species in the world, would have returned far more results than this review had the resources to manage.

2. Cumulative impacts on 'threatened species' in ecosystems: There is a strong argument, that the impact of invasive species on 'threatened species' should not be considered in isolation but in light of all other factors which in combination impact native species [14]. 'threatened species' exist in complex ecosystems which are influenced by numerous overlapping factors with cumulative reinforcing impacts. Factors such as climate and human activities work in combination with invasions to shape ecosystems and their species. To fully understand the impact invasive species have on 'threatened species' it would have been better to have studied the combined impact of all factors at both an ecosystem and a species level. While theoretically valuable, widening the research question to all impacts would have been far outside the resources allocated to this Systematic Review. Furthermore, expanding the search string to reflect a wider question of all impacts would have been likely to have significantly increased the number of studies that needed screening but unlikely to have produced many studies with useable results. It is difficult to measure each of these impacts individually, let alone in combination, and even more so to discern the proportional impact when they are studied collectively. The focus of the Systematic Review might not have found the fullest ecological 
answer but it gave one that was achievable with the resources and evidence available and provides a very strong starting point to set priorities and direct management decisions in invasive species and 'threatened species' programmes.

3. Non-English language studies: All studies not written in English were automatically excluded from the study (though saved in a separate EndNote library). It is possible that these non-English language studies may have included useful evidence on the impact of invasive species on 'threatened species' in the USA. It was outside the resources of this review to have these papers translated or assessed by foreign language experts. This library can, however, be called upon should new funding arise or should others wish to assess the evidence within them and add it to the review.

\section{Ethical constraints}

1. Ethical issues in studying 'threatened species': There are ethical issues in conducting studies where the subject is a 'threatened species'. Normally quality design is assessed heavily on the number of replicates and whether an appropriate control has been established. This is very difficult to ensure when dealing with 'threatened species' as the more replicates and control groups, the more "threatened" individuals are essentially being sacrificing to study design. And while understanding a problem is important and can help protect more species in the future, ethically, preserving a species at the present time may often be judged of greater importance. It is likely for this reason that so much of the evidence collected within this study is based on observational data and time-series studies based on natural experiments rather than higher quality research designs. This is an obvious limitation in the research methods used in the primary studies, rather than in the design of this Systematic Review.

\section{Research limitations}

1. Anecdotal evidence excluded: Policy makers are increasingly being called upon to base policies on evidence. The goal of this Systematic Review was to collate the evidence behind the COP10 statement and assess "What is the evidence that invasive species are a significant contributor to the decline or loss of threatened species". In doing so criteria were set as to what counted as acceptable evidence. Given the ethical and practical difficulties outlined in studying the impact, the evidence bar was set at a pragmatic level. Data needed to be at least observational- a witness or researcher had to observe something at least once. Many documents that were screened, in particular recovery/management plans, contained a lot of anecdotal data. They alluded to impacts, sometimes even between specific pairs, but gave no reasons to believe such assertions were based on primary or even secondary evidence. This is most problematic because those statements seem likely to be based on something - such as field observations, which could have been included in the review if they had been recorded adequately. The stronger the evidence base that the scientific community can collate, the more weight that evidence will have steering policy priorities and actions.

2. Quality of the evidence: The majority of evidence was from observational data (43\%), and timeseries data (23\%), which was largely correlation data from opportunistic "natural-experiments". These experimental designs often lack controls, replications and measurements of various effect modifiers. They have a high potential to report correlation and present it as causation. 
Constraints on conducting appropriate experiments have been discussed. As such it is understandable that the majority of evidence is derived from observational data and natural experiments and while imperfect data, taken together it can be suggestive $\mathrm{n}$ identifying trends and highlighting where impacts are likely to occur. Gurevitch and Padilla [2] write that "Although it is clear that obtaining quantitative and experimental data are impossible under many circumstances, the problem remains that correlation is too often assumed to imply causation." One of the strengths of the Systematic Review methodology is that for every study providing evidence the quality of the research methods used to collect that evidence are assessed and presented alongside the evidence. This helps those reviewing the evidence, collectively, and making policy/management decisions based upon it, to do so in full knowledge of the quality of the foundations they are basing their decisions on.

3. Meta-analysis was not possible: Because the data quality was limited and most of it lacked quantified measures of impact with little or no mention or quantification of effect modifiers, it was not possible to perform formal meta-analysis in this Systematic Review. Ideally, metaanalysis could have proved useful in providing a definitive answer, from the available evidence, to the primary research question the fact that $80 \%$ off all of the evidence found invasive species to have a negative impact on 'threatened species' speaks overwhelmingly that there is enough evidence for both concern and action. What has emerged from analysis of the two sub-questions is far more useful for setting priorities and highlighting points of management intervention that a simple yes/no answer to the primary research question.

4. A map of evidence incomplete: It would be very useful to have a definitive map of what invasive species are impacting which 'threatened species' where. This Systematic Review starts that map and can help policy makers and land managers to know what is already known within their respective States and to set priorities between those species. However the map is not exhaustive- it is more so a map of what has been studied than a complete map of evidence. Obviously a complete map of the evidence would be more useful but this review could only gather the evidence that was there. What is so fortunate, in this instance, about the nature of Systematic Review methods is that due to clear and transparent procedure it is possible for this map to be added to through periodical updates of the review.

\section{Research gaps identified}

1. Geographical range: It was necessary within the resources and time available to this review to limit the scope to consider just US FWS 'threatened species' up to. By doing so this largely limited the geographical range to the USA. Studies were not excluded based on their geographical location. So if a study contained evidence of an invasive species impacting a US FWS 'threatened species' it was included irrespective of which country t was studied in. While this is a limitation, it is probably not as limiting as it might first seem based on purely geographical terms. Much of the research on the topic is likely to come from the USA, where funding budgets are relatively high and research is active. There are fewer studies emerging from developing countries. This is of concern as invasive species are likely to have an amplified impact in developing countries where reliance on natural resource is so much higher. While this work does focus on the USA, its impact stretches beyond those geographical boundaries. Countries with little of their own primary research, in particular developing countries, still need 
to set priorities and decide upon management of invasive species and protection of their biodiversity to avoid the extinction of their threatened species. These should be based on the best evidence available which is likely to necessitate using lessons learned from other geographical regions with more primary research done. This review provides the most comprehensive summary of that evidence that is available to date at such a broad taxonomic and species scale.

2. Methodological improvements: It is understandable why the number of carefully controlled scientific trials around this topic is very low. However, improvements are needed in the way scientists and land managers are recording data. In particular, observational data can and should be recorded in a more useful way. There was an enormous wealth of anecdotal statements of ' $x$ invasive species impacts ' $y$ 'threatened species" in the literature. However these statements came with no acknowledgement as to what they are based on. It is likely that some of these statements will be based on field observations or on trends noticed over time, but unless that is explicitly stated it cannot be used as observational data and has to be assumed to be an opinion - which obviously does not count as primary scientific evidence in a Systematic Review. One of the key lessons that can be learnt from this Systematic Review should be easy to adopt: that scientist and land managers need to be more thorough in the way they record and present observational data. It is essential to state that it is an observation that has been recorded, when it was made, what was seen (including GPS coordinated if possible). Such data would have limitations but would be useable, in contrast to anecdotal statements.

3. Improved auditing in management documents: Management documents need to have a much stronger audit trail of where information comes from. While assessing management documents, a lot of anecdotal evidence was found that was not referenced. The documents are clearly based on considerable work and probably a good degree of primary evidence, but unless that evidence was referenced it could not be followed back so that it could be included in the review. Given the difficult nature of collecting primary research on invasive species causing extinctions, much evidence may be observations and small-scale studies which emerge internally within organisations and may not be published. This evidence serves its purpose in management documents, but cannot be used further when it has no record of where it has come from and what it is based upon. For wider research purposes it is essential that all evidence presented in management documents is referenced and presented with a clear account of what it is: whether it is just an opinion or is it an observation, or noticed trend, or a small-scale study.

\section{Recommendations for further development of the map}

1. Increase geographical and taxonomic scope: Additionally the geographical and taxonomic scope of this review should be expanded to include the global IUCN lists critically endangered species.

2. Periodical updates of the map: A key advantage of Systematic Reviews is that their set and transparent methods make it possible to update and develop the work. Systematic Reviews may be updated once a significant wealth of new evidence is published. The timing of this will depend on the topic of the review and how actively it is being researched. Once a significant wealth of new evidence has emerged, the methods are repeated with a time filter to capture all evidence published after the last search date. 
3. Include non-English studies: Non-English studies which were excluded (but recorded) in this review could be assessed and the evidence within them added to the map. Additionally the search could be repeated with translated versions of the search string to collect further evidence from non-English studies which will have been missed by the present review.

4. Include marine species: The present Systematic Review limited the impacted species to US FWS 'threatened species'. This list covers terrestrial and some freshwater species but not marine or androgynous species. A highly appropriate development of the map would be to conduct a new search including US listed National Marine and Freshwater Species (NMFS) listed and candidate species.

\section{Review Conclusions}

\section{Implication for Policy/Management}

This review assists policy makers and land managers in three fundamental ways: First, it demonstrates the evidence-based foundations for the argument that programmes and projects on invasive species causing extinctions should be high on political agendas. Second, policy makers and land managers can use the information presenting invasive species paired with native 'threatened species' that they are impacting upon to help them to set priorities for the control of invasive species and the protection of 'threatened species', as well as highlighting research gaps of potential interactions which have not yet been studied. Lastly, the information collected on the mechanism of impact can be used to identify points of management intervention.

\section{Evidence-based foundations}

This Systematic Review came out of a need to collate the scientific evidence on the impact that invasive species have on threatened species. Prior to this review the evidence had not been summarised collectively over a large geographical area and between such a broad range of taxa. The COP 10 statement placed the issue high on the minds of policy makers but without any firm evidence-based foundations for it being there. The political world is moving more towards an arena of evidence based policy. Resources are always limited, as such, there needs to be a basis for deciding which topics are priorities and converted to policy and which actions within policies need to be appropriately prioritised. It is logical that all of these decisions are based on the evidence available. Within this context USDA, who commissioned this Systematic Review, needed to determine if their ICE programme was responding to evidence backed need.

This Systematic Review has found that of all the evidence that was identified on the impact of invasive species on US FWS 'threatened species', $80 \%$ found that impact to be negative. This is enough evidence to create cause for concern and to make the topic a policy priority. Even though the impact of invasive species has only been studied for $6.5 \%$ of all US FWS 'threatened species', the fact that $80 \%$ of this evidence shows a negative impact necessitates a precautionary principle approach to the issue. Although we may not have the full evidence base, the evidence we do have is of grave enough concern to prioritise policies on the topic. This Systematic Review gives assurance that the focus on programmes on invasive species causing extinctions is scientifically justified. Specifically it shows the USDA ICE programme is based on science. 
While the weight of negative evidence gives confidence to the need to prioritise these programmes the evidence base is far from complete. The impact of invasive species was only found to have been measured for $6.5 \%$ of all US FWS 'threatened species' and for those species $80 \%$ of the evidence was negative. It seems highly likely that if studies were done for the remaining $93.5 \%$ of species, more evidence will be found. It is land managers who are on the ground making observations about the impact invasive species are having on native species. These land managers need to record evidence in better ways and ensuring it is available to policy makers. They need guidance on how observational data can be best recorded so it moves beyond anecdotal statements and becomes useable scientific data. It is essential to record who made the observation, when, where, over how many occasions and what exactly has been observed, and if possible the location and GPS coordinates of the observation. It might be useful if the USDA, FWS and NMFS were to create a central database for logging this information. This will allow the full evidence of the impact of invasive species impacting 'threatened species' to be collected with greater ease and speed.

\section{Setting priorities based on species pairs evidence}

This Systematic Review Maps all evidence found on the impact of invasive species on US FWS 'threatened species'. This map can itself be used to set priorities. Appendix 3 gives an entry point for identifying which invasive species land managers should be controlling and Appendix 4 which 'threatened species' should be protected. That is not to say that other species not in these should not receive attention but more to summarise for which species there are evidence-based grounds for knowing action is needed.

While it is useful to have lists of invasive species needing control and 'threatened species' needing protection, these lists probably outstretch the resources available and it is necessary to be able to set within the evidence. A number of ways policy makers and land managers may set priorities within the identified evidence are proposed.

1. Prioritise by threatened status ranking: One of the most obvious ways to set priorities within the mapped lists of invasive species causing negative impacts (appendix 3 ) and 'threatened species' being negatively impacted (appendix 4) is to break the lists down into the status of the threatened species being impacted. USA endangered species should be protected before USA threatened species, and threatened species before USA candidate ones. The problem with endangerment is that once the tipping point is passed and the last individual is gone there is no way back. Species are given an endangered status because their numbers are so low and their presence is often restricted to just a few localised populations and once that isolated population is gone, there are no others.

2. Prioritise by 'threatened species' undergoing multiple invasions: Another way policy makers and land managers can use the results of this Systematic Review Map to prioritise can be set within the evidence found is to look at multiple invasions. This can be approached in two ways. The first is to use Appendix 3 to identify invasive species which impact multiple 'threatened species' and if these 'threatened species' are known to co-inhabit the same ecosystems then to prioritise the control of that invasive species and limit its spread to areas where those 'threatened species' are co-inhabiting. As Gurevitch and Padilla (2004) clearly explain "Even within functional groups, a few species appear to have caused a disproportionate share of 
incipient and actual extinctions". Focusing on these species can help to mitigate the impact that such prolific species have. Second, is to use Appendix 4 to identify 'threatened species' which are vulnerable to negative impacts from multiple invasive species. These species are especially vulnerable and their protection should be prioritised.

3. Prioritise direct impacts over indirect impacts: Invasive species become intrinsic part of the ecosystems they enter. They have both direct impacts on native species and cascading indirect effect through abiotic factors of intermediary species. When setting priorities it can be easy to simply focus on the obvious direct impacts - as these are easier to observe and act upon. Indirect impacts - subtle changes to abiotic factors or indirect changes to complex food webs - can be far less easy to identify and attribute the responsibility back to the invasive. There is far less reliable data on these kinds of indirect effects but it is important that policy makers and land managers keep them in mind.

"Exotic species might be a primary cause for decline, a contributing factor for a species already in serious trouble, the final nail in the coffin or merely the bouquet at the funeral."

(Gurevitch and Padilla, 2004).

4. Identifying points of management intervention based on the mechanism of impact: The budgets and efforts of policy makers and land managers are always limited. For this reason it is essential to be able to set priorities but within species priorities is essential to know what can be done about an identified impact. It is not enough to simply know that an impact is occurring. If you cannot understand how an invasive species is impacting a 'threatened species', it is very difficult to know what can be done about it. As Gurevitch and Padilla (2004) state "The better we understand both patterns and mechanisms causing declines, the better we can focus our efforts on the most effective ways to reduce or mitigate threats." Understanding the mechanisms of impact allows points of management intervention to be identified to nullify or disrupt such mechanisms.

Practical management necessitates focusing on which invasive species cause the biggest impact/risk and select what can feasibly be done about it. Sometimes even when a particular invasive species is identified as a large problem it is not possible to remove it. However, it may, be possible to control it. Through understanding the way it impacts other species it is also possible to identify control strategies. For example, attempts to completely remove water hyacinth from Lake Victoria, Africa have failed. However, by understanding the ways in which the weed shades out light from the lake to the severe detriment of other native fish it become clear that removing the bulk of the hyacinth in regular dredging regimes can allow enough light for some of the native fish to survive.

Mechanisms used by the invasive species were extracted from the primary research and presented alongside the evidence. This was done so than policy makers and land managers know where evidence exists and can see what that evidence tells us about how impacts are occurring. By understanding the 'how' of impact it becomes possible to identify points of management intervention in cases where full invasive species control is not possible. 


\section{Implications for Research}

1. Urgent need for more research is evidentially founded: What is absolutely clear from this Systematic Review is that more research is needed. The grounds to desire further research are founded in evidence provided by this systematic review. Only $6.5 \%$ of US FWS 'threatened species' had been studied to consider the impact of invasive species on them but from those $80 \%$ of all of the evidence was negative. Mapping the evidence of what we know about these $6.5 \%$ of species will help to set priorities but it will not help to set priorities on the rest of the species that we have no information about. It is essential this map is used to highlight research gaps and understand if and how invasive species are impacting the remaining $93.5 \%$ of US FWS 'threatened species'.

2. Identifies specific research gaps: The map can be used in several ways to highlight research gaps depending on the priorities of those supporting the research. The data can highlight 'threatened species' for which there is currently no impact data, invasive species whose impact has not been considered or States and habitats which have been understudied.

Dissemination of results is an integral part of the Systematic Review methodology. Efforts will be made to ensure the research gaps identified by the Systematic Review Map will be presented to the appropriate research entities at federal, state and private levels. At the US federal level this includes dissemination to the USDA, the US Forestry Service, and the US Agricultural Research Institute, the US National Institute of Food and Agriculture, and the US National Resource Conservation Service. and the US Department for the Interior. At the state level this includes the Land Grant Universities and the private level the non-governmental organisations and industries that conduct research. The results will be disseminated in the most appropriate format for their intended recipient- in this case this will likely to be in the form of a small series of policy briefs.

The results will also be shared with the Invasive Species Compendia: an open- access and free resource of invasive species datasheets detailing the impact of invasive species on biodiversity and their prevention and control.

In doing so they will be able to update present datasheets with new evidence and where evidence has been identified and a datasheets does not yet exist set commissioning priorities to ensure those datasheets are written.

3. Identifies improvements to research methods: The research methods used in the primary studies from which this Systematic Review collates its evidence is not very high. There a number of good reasons why the data tends to be collected via lower quality research methods, such as field observations and correlation data measured in natural experiments. However there are also a number of subtle changes which can be made in data collection which will greatly improve the quality of data collected. Two points seems absolutely clear. Firstly we need to move away from anecdotal statements about invasive species ' $x$ ' impacting threatened species ' $y$ '. Many of these statements are likely to be more than opinion and are often either un-cited references to other people's findings or primary observation. Either way that audit train needs to be made plain. There is a whole wealth of knowledge which is unusable as primary evidence because it is just not documented with a clear audit trail. Secondly when an observation is presented it needs to be done so well. This isn't difficult in the way conducting a carefully controlled RCT is but can 
make all of the difference. It is absolutely key to record who made and observation, where it was noticed, when and over what duration of time is was observed, then as much detail of what has been observed as possible. Simply doing so converts throwaway anecdotal statements into useable evidence.

\section{Conclusion}

There is broad scientific consensus that invasive species are likely to play a crucial and devastating role in driving species extinctions. This Systematic Review set out to collect all of the available evidence relating to this claim for US FWS 'threatened species'. This is the first time all evidence has been collated at such a large taxonomic or geographical scale. The review found that the topic has been vastly understudied. Despite the level of concern raised in the COP10 statement, when considering all US FWS 'threatened species', for only $6.5 \%$ have studies of the impact of invasive species been conducted and published. The reasons for this lack of evidence will be explored subsequently. What is most striking, is that, despite the limited number of studies, where evidence does exist it was overwhelmingly negative. Of all studies that investigated the impact of invasive species on US 'threatened species' $80 \%$ (158 cases of evidence) reported a negative impact. This dominance of negative interactions is a clear evidence-based message to policy makers and land managers of the importance of the impact that invasive species are having on already imperilled species.

\section{Competing interests}

No conflict of interests to declare.

Funding disclosure: This report is submitted as a partnership between $\mathrm{CABI}$, the National Marine Fisheries Service (NMFS), CBSG/IUCN and USDA's Invasive Species Coordination Program. The funding for this review comes from the USDA Invasive Species Coordination Program, managed by Ms. Hilda Diaz-Soltero, USDA Senior Invasive Species Coordinator, who is an advisor to the review team but not taking an active role in any phase of the selection and reviewing of the evidence captured by the CABI review team.

\section{Acknowledgments}

The review team would like to thank Eileen Welsh and Lara Boeck, APHIS Libraries, for all her assistance in locating and providing access to US documents species plans and listing documents along with non-web based publications.

\section{References}

[1] Clavero M, Garci-Berthou E: Invasive species are a leading cause of animal extinctions. TRENDS in Ecology and Evolution 2005, 20 (3):110.

[2] Gurevitch J, Padilla DK: Are invasive species a major cause of extinctions? TRENDS in Ecology and Evolution 2004, 19:470-474.

[3] Miller RR, Williams JD, Williams JE: Extinctions of North American fishes during the past century. Fisheries 1989, 14:22-38. 
[4] Burbidge AA, Manly FJ: Mammal extinctions on Australian islands: causes and conservation implications. Journal of Biogeography 2002, 29:465-473.

[5] Moher D, Cook DJ, Eastwood S, Olkin I, Rennie D, Stroup DF: Improving the quality of reports of meta-analysis of randomised controlled trials: the QUOROM statement - Review. Lancet 1999, 354:1896-1900.

[6] McNeely JA, Mooney HA, Neville LE, Schei PJ, Waage JK: Global Strategy on Invasive Alien Species. IUCN, Gland, Switzerland and Cambridge UK; 2001.

[7] Stevens A, Milne R: From The effectiveness revolution and public health. In Progress in Public Health. Edited by Scalley G. London: Royal Society for Medicine Press; 1997:197-225.

[8] Pullin AS, Knight TM: Support for decision making in conservation practice: an evidence-based approach. Journal for Nature Conservation 2003, 11 (2):83-90.

[9] Roberts PD, Diaz-Soltero H, Hemming DJ, Parr MJ, Wakefield NH, Wright HJ What is the evidence that invasive species are a significant contributor to the decline or loss of threatened species? A Systematic Review Map. Environmental Evidence 2013 2: 5 doi:10.1186/2047-2382-2-5

[10] Fitzpatrick BM, Johnson JR, et al. Rapid spread of invasive genes into a threatened native species. Proc Natl Acad Sci USA 2010 107:3606-3610

[11] Hellmair M, Goldsmith G, et al. Preying on invasive species: the exotic New Zealand mudsnail in the diet of the endangered tidewater goby. Biological Invasions 2011 13: 2197-2201.

[12] Klinger RC, Schuyler P, et al. The response of herbaceous vegetation and endemic plant species to the removal of feral sheep from Santa Cruz Island, California. Occasional Paper of the IUCN Species Survival Commission No.27. 2003 Gland, IUCN-The World Conservation Union: 141-154.

[13] Russell DJ, Balazs GH,. Colonization by the alien marine alga Hypnea musciformis (Wulfen) J. Ag. (Rhodophyta: Gigartinales) in the Hawaiian islands and its utilization by the green turtle, Chelonia mydas L. Aquatic Botany 1994 47: 53-60.

[14] Masters G., Norgrove L. 2010. Climate change and invasive alien species. CABI working paper. $1,30 \mathrm{pp}$

\section{Appendix One: Species list of the review for secondary question 1}

1.1. Search string for listed US endangered and 'threatened species' (from US Fish and Wildlife Service, (http://www.fws.gov/endangered/species/us-species.html)): ("invasive species" OR "invasive alien species" OR IAS OR feral OR "introduced species" OR "non-indigenous" OR alien OR "invasive plant" OR "invasive weed" OR exotic OR "non-native") AND ("Abornia macrocarpa" OR "Abronia alpina" OR "Abutilon eremitopetalum" OR "Abutilon menziesii" OR "Abutilon sandwicense" OR "Acaena exigua" OR "Acanthomintha ilicifolia" OR "Acanthomintha obovata" OR "Accipiter striatus venator" OR Achatinella OR "Achyranthes mutica" OR "Achyranthes splendens" OR "Acipenser brevirostrum" OR "Acipenser 
medirostris" OR "Acipenser oxyrinchus desotoi" OR "Acipenser transmontanus" OR "Aconitum noveboracense" OR "Acrocephalus familiaris kingi" OR "Acrocephalus luscinia" OR "Acropora cervicornis" OR "Acropora palmata" OR "Adelocosa anops" OR "Adenophorus periens" OR "Adiantum vivesii" OR "Aerodramus vanikorensis bartschi" OR "Aeschynomene virginica" OR "Agalinis acuta" OR "Agave eggersiana" OR "Agelaius xanthomus" OR "Alasmidonta atropurpurea" OR "Alasmidonta heterodon" OR "Alasmidonta raveneliana" OR "Alectryon macrococcus" OR "Alligator mississippiensis" OR "Allium munzii" OR "Alopecurus aequalis" OR "Alsinidendron lychnoides" OR "Alsinidendron obovatum" OR "Alsinidendron trinerve" OR "Alsinidendron viscosum" OR "Amaranthus brownii" OR "Amaranthus pumilus" OR "Amazona viridigenalis" OR "Amazona vittata" OR "Amblema neislerii" OR "Amblyopsis rosae" OR "Ambrosia cheiranthifolia" OR "Ambrosia pumila" OR "Ambrysus amargosus" OR "Ambrysus funebris" OR "Ambystoma bishopi" OR "Ambystoma californiense" OR "Ambystoma cingulatum" OR "Ambystoma macrodactylum croceum" OR "Ambystoma tigrinum stebbinsi" OR "Ameiva polops" OR "Ammodramus maritimus mirabilis" OR "Ammodramus savannarum floridanus" OR "Amorpha crenulata" OR "Amphianthus pusillus" OR "Amphispiza belli clementeae" OR "Amsinckia grandiflora" OR "Amsonia kearneyana" OR "Anaea troglodyta floridalis" OR "Anas laysanensis" OR "Anas wyvilliana" OR "Anaxyrus canorus" OR "Ancistrocactus tobuschii" OR "Anguispira picta" OR "Anolis roosevelti" OR "Anthus spragueii" OR "Antilocapra americana sonoriensis" OR "Antrobia culveri" OR "Antrolana lira" OR "Aphelocoma coerulescens" OR "Apios priceana" OR "Aplodontia rufa nigra" OR "Apodemia mormo langei" OR "Arabis georgiana" OR "Arabis hoffmannii" OR "Arabis macdonaldiana" OR "Arabis perstellata" OR "Arabis serotina" OR "Arctocephalus townsendi" OR "Arctomecon humilis" OR "Arctostaphylos confertiflora" OR "Arctostaphylos glandulosa" OR "Arctostaphylos hookeri" OR "Arctostaphylos morroensis" OR "Arctostaphylos myrtifolia" OR "Arctostaphylos pallida" OR "Arenaria cumberlandensis" OR "Arenaria paludicola" OR "Arenaria ursina" OR "Argemone pleiacantha" OR "Argyroxiphium kauense" OR "Argyroxiphium sandwicense" OR "Argythamnia blodgettii" OR "Aristida chaseae" OR "Aristida portoricensis" OR "Arkansia wheeleri" OR "Artemisia borealis" OR "Asclepias meadii" OR "Asclepias welshii" OR "Asimina tetramera" OR "Asplenium fragile" OR "Asplenium scolopendrium" OR "Assiminea pecos" OR "Astelia waialealae" OR "Astragalus albens" OR "Astragalus ampullarioides" OR "Astragalus anserinus" OR "Astragalus applegatei" OR "Astragalus bibullatus" OR "Astragalus brauntonii" OR "Astragalus clarianus" OR "Astragalus cremnophylax" OR "Astragalus cusickii" OR "Astragalus desereticus" OR "Astragalus holmgreniorum" OR "Astragalus humillimus" OR "Astragalus jaegerianus" OR " Astragalus lentiginosus" OR "Astragalus magdalenae" OR "Astragalus microcymbus" OR "Astragalus montii" OR "Astragalus osterhoutii" OR "Astragalus phoenix" OR "Astragalus pycnostachyus" OR "Astragalus robbinsii" OR "Astragalus schmolliae" OR "Astragalus tener" OR "Astragalus tortipes" OR "Astragalus tricarinatus" OR "Astrophytum asterias" OR "Athearnia anthonyi" OR "Atlantea tulita" OR "Atriplex coronata" OR "Auerodendron pauciflorum" OR "Ayenia limitaris" OR "Baccharis vanessae" OR "Balaena mysticetus" OR "Balaenoptera borealis" OR "Balaenoptera musculus" OR "Balaenoptera physalus" OR "Banara vanderbiltii" OR "Baptisia arachnifera" OR "Batrachoseps aridus" OR "Batrisodes texanus" OR "Batrisodes venyivi" OR "Berberis nevinii" OR "Berberis pinnata" OR "Betula uber" OR "Bidens campylotheca pentamera" OR "Bidens campylotheca waihoiensis" OR "Bidens conjuncta" OR "Bidens 
micrantha ctenophylla" OR "Bidens micrantha" OR "Bidens wiebkei" OR "Bison bison athabascae" OR "Blennosperma bakeri" OR "Boechera pusilla" OR "Boloria acrocnema" OR "Boltonia decurrens" OR "Bonamia grandiflora" OR "Bonamia menziesii" OR "Brachylagus idahoensis" OR "Brachyramphus brevirostris" OR "Brachyramphus marmoratus" OR "Branchinecta conservatio" OR "Branchinecta longiantenna" OR "Branchinecta lynchi" OR "Branchinecta sandiegonensis" OR "Branta sandvicensis" OR "Brickellia mosieri" OR "Brighamia insignis" OR "Brighamia rockii" OR "Brodiaea filifolia" OR "Brodiaea pallida" OR "Brychius hungerfordi" OR "Bufo baxteri" OR "Bufo californicus" OR "Bufo houstonensis" OR "Buteo platypterus brunnescens" OR "Buteo solitarius" OR "Buxus vahlii" OR "Caesalpinia kavaiense" OR "Calamagrostis expansa" OR "Calamagrostis hillebrandii" OR "Calidris canutus rufa" OR "Callicarpa ampla" OR "Callirhoe scabriuscula" OR "Callophrys mossii bayensis" OR "Calochortus persistens" OR "Calochortus tiburonensis" OR "Calyptranthes thomasiana" OR "Calyptridium pulchellum" OR "Calyptronoma rivalis" OR "Calystegia stebbinsii" OR "Cambarus aculabrum" OR "Cambarus zophonastes" OR "Camissonia benitensis" OR "Campanula robinsiae" OR "Campeloma decampi" OR "Campephilus principalis" OR "Canavalia molokaiensis" OR "Canavalia napaliensis" OR "Canavalia pubescens" OR "Canis lupus" OR "Canis rufus" OR "Caprimulgus noctitherus" OR "Cardamine micranthera" OR "Caretta caretta" OR "Carex albida" OR "Carex lutea" OR "Carex specuicola" OR "Castilleja affinis" OR "Castilleja campestris" OR "Castilleja christii" OR "Castilleja cinerea" OR "Castilleja grisea" OR "Castilleja levisecta" OR "Castilleja mollis" OR "Catesbaea melanocarpa" OR "Catostomus discobolus yarrowi" OR "Catostomus microps" OR "Catostomus santaanae" OR "Catostomus warnerensis" OR "Caulanthus californicus" OR "Ceanothus ferrisae" OR "Ceanothus ophiochilus" OR "Ceanothus roderickii" OR "Cenchrus agrimonioides" OR "Centaurium namophilum" OR "Centaurium sebaeoides" OR "Centrocercus minimus" OR "Centrocercus urophasianus" OR "Centrocercus urophasianus" OR "Cercocarpus traskiae" OR "Cereus eriophorus" OR "Chamaecrista glandulosa" OR "Chamaecrista lineata keyensis" OR "Chamaesyce celastroides" OR "Chamaesyce deltoidea pinetorum" OR "Chamaesyce deltoidea serpyllum" OR "Chamaesyce deltoidea" OR "Chamaesyce deppeana" OR "Chamaesyce eleanoriae" OR "Chamaesyce garberi" OR "Chamaesyce halemanui" OR "Chamaesyce herbstii" OR "Chamaesyce hooveri" OR "Chamaesyce kuwaleana" OR "Chamaesyce remyi" OR "Chamaesyce rockii" OR "Chamaesyce skottsbergii" OR "Charadrius alexandrinus nivosus" OR "Charadrius melodus" OR "Charpentiera densiflora" OR "Chasiempis sandwichensis ibidis" OR "Chasmistes brevirostris" OR "Chasmistes cujus" OR "Chasmistes liorus" OR "Chelonia mydas" OR "Chionactis occipitalis klauberi" OR "Chionanthus pygmaeus" OR "Chlorogalum purpureum" OR "Chorizanthe howellii" OR "Chorizanthe orcuttiana" OR "Chorizanthe parryi" OR "Chorizanthe pungens" OR "Chorizanthe robusta" OR "Chorizanthe valida" OR "Chromolaena frustrata" OR "Chrysopsis floridana" OR "Cicindela albissima" OR "Cicindela dorsalis dorsalis" OR "Cicindela highlandensis" OR "Cicindela nevadica lincolniana" OR "Cicindela ohlone" OR "Cicindela puritana" OR "Cicurina baronia" OR "Cicurina madla" OR "Cicurina venii" OR "Cicurina vespera" OR "Cicurina wartoni" OR "Cirsium fontinale" OR "Cirsium hydrophilum" OR "Cirsium loncholepis" OR "Cirsium pitcheri" OR "Cirsium vinaceum" OR "Cirsium wrightii" OR "Cladonia perforata" OR "Clarkia franciscana" OR "Clarkia imbricata" OR "Clarkia speciosa" OR "Clarkia springvillensis" OR "Clematis morefieldii" OR "Clematis socialis" OR "Clemmys muhlenbergii" OR "Clermontia drepanomorpha" OR "Clermontia 
lindseyana" OR "Clermontia oblongifolia" OR "Clermontia peleana" OR "Clermontia pyrularia" OR "Clermontia samuelii" OR "Clitoria fragrans" OR "Colinus virginianus ridgwayi" OR "Colubrina oppositifolia" OR "Columba inornata wetmorei" OR "Conradilla caelata" OR "Conradina brevifolia" OR "Conradina etonia" OR "Conradina glabra" OR "Conradina verticillata" OR "Cordia bellonis" OR "Cordylanthus maritimus" OR "Cordylanthus mollis" OR "Cordylanthus palmatus" OR "Cordylanthus tenuis" OR "Cornutia obovata" OR "Corvus hawaiiensis" OR "Corvus kubaryi" OR "Corvus leucognaphalus" OR "Corynorhinus townsendii ingens" OR "Corynorhinus townsendii virginianus" OR "Coryphantha minima" OR "Coryphantha ramillosa" OR "Coryphantha robbinsorum" OR "Coryphantha scheeri" OR "Coryphantha sneedii" OR "Cottus paulus" OR "Cranichis ricartii" OR "Crenichthys baileyi baileyi" OR "Crenichthys baileyi grandis" OR "Crenichthys nevadae" OR "Crescentia portoricensis" OR "Crocodylus acutus" OR "Crotalaria avonensis" OR "Crotalus willardi obscurus" OR "Cryptantha crassipes" OR "Cryptobranchus alleganiensis bishopi" OR "Ctenitis squamigera" OR "Cucurbita okeechobeensis" OR "Cumberlandia monodonta" OR "Cupressus abramsiana" OR "Cupressus goveniana" OR "Cyanea crispa" OR "Cyanea acuminata" OR "Cyanea asarifolia" OR "Cyanea copelandii" OR "Cyanea dolichopoda" OR "Cyanea dunbarii" OR "Cyanea eleeleensis" OR "Cyanea glabra" OR "Cyanea grimesiana" OR "Cyanea hamatiflora" OR "Cyanea humboldtiana" OR "Cyanea kolekoleensis" OR "Cyanea koolauensis" OR "Cyanea kuhihewa" OR "Cyanea lobata" OR "Cyanea longiflora" OR "Cyanea macrostegia" OR "Cyanea mannii" OR "Cyanea mceldowneyi" OR "Cyanea pinnatifida" OR "Cyanea platyphylla" OR "Cyanea procera" OR "Cyanea recta" OR "Cyanea remyi" OR "Cyanea shipmanii" OR "Cyanea st.-johnii" OR "Cyanea stictophylla" OR "Cyanea superba" OR "Cyanea truncata" OR "Cyanea undulata" OR "Cyathea dryopteroides" OR "Cycladenia jonesii" OR "Cyclura cornuta stejnegeri" OR "Cynomys parvidens" OR "Cyperus trachysanthos" OR "Cyprinella caerulea" OR "Cyprinella formosa" OR "Cyprinodon bovinus" OR "Cyprinodon diabolis" OR "Cyprinodon elegans" OR "Cyprinodon macularius" OR "Cyprinodon nevadensis mionectes" OR "Cyprinodon nevadensis pectoralis" OR "Cyprinodon radiosus" OR "Cyprogenia stegaria" OR "Cyrtandra crenata" OR "Cyrtandra cyaneoides" OR "Cyrtandra dentata" OR "Cyrtandra giffardii" OR "Cyrtandra limahuliensis" OR "Cyrtandra munroi" OR "Cyrtandra oenobarba" OR "Cyrtandra paliku" OR "Cyrtandra polyantha" OR "Cyrtandra subumbellata" OR "Cyrtandra tintinnabula" OR "Cyrtandra viridiflora" OR "Dalea foliosa" OR "Daphnopsis hellerana" OR "Deeringothamnus pulchellus" OR "Deeringothamnus rugelii" OR "Deinandra conjugens" OR "Deinandra increscens" OR "Delissea rhytidosperma" OR "Delissea rivularis" OR "Delissea subcordata" OR "Delissea undulata" OR "Delphinapterus leucas" OR "Delphinium bakeri" OR "Delphinium luteum" OR "Delphinium variegatum" OR "Deltistes luxatus" OR "Dendroica chrysoparia" OR "Dendroica kirtlandii" OR "Dermochelys coriacea" OR "Desmocerus californicus dimorphus" OR "Dicerandra christmanii" OR "Dicerandra cornutissima" OR "Dicerandra frutescens" OR "Dicerandra immaculata" OR "Diellia erecta" OR "Diellia falcata" OR "Diellia mannii" OR "Diellia pallida" OR "Diellia unisora" OR "Dinacoma caseyi" OR "Dionda diaboli" OR "Diplazium molokaiense" OR "Dipodomys heermanni morroensis" OR "Dipodomys ingens" OR "Dipodomys merriami parvus" OR "Dipodomys nitratoides exilis" OR "Dipodomys nitratoides nitratoides" OR "Dipodomys stephensi" OR "Discus macclintocki" OR "Dodecahema leptoceras" OR "Doryopteris angelica" OR "Dromus dromas" OR "Drosophila aglaia" OR "Drosophila differens" OR "Drosophila hemipeza" OR 
"Drosophila heteroneura" OR "Drosophila montgomeryi" OR "Drosophila mulli" OR "Drosophila musaphila" OR "Drosophila neoclavisetae" OR "Drosophila obatai" OR "Drosophila ochrobasis" OR "Drosophila sharpi" OR "Drosophila substenoptera" OR "Drosophila tarphytrichia" OR "Drymarchon corais couperi" OR "Dryopteris crinalis" OR "Dubautia herbstobatae" OR "Dubautia imbricata imbricata" OR "Dubautia kalalauensis" OR "Dubautia kenwoodii" OR "Dubautia latifolia" OR "Dubautia pauciflorula" OR "Dubautia plantaginea magnifolia" OR "Dubautia plantaginea" OR "Dudleya abramsii" OR "Dudleya cymosa" OR "Dudleya nesiotica" OR "Dudleya setchellii" OR "Dudleya stolonifera" OR "Dudleya traskiae" OR "Dudleya verityi" OR "Echinacea laevigata" OR "Echinocactus horizonthalonius" OR "Echinocereus chisoensis" OR "Echinocereus fendleri" OR "Echinocereus reichenbachii" OR "Echinocereus triglochidiatus" OR "Echinocereus viridiflorus" OR "Echinomastus mariposensis" OR "Elaphoglossum serpens" OR "Elaphrus viridis" OR "Eleutherodactylus cooki" OR "Eleutherodactylus jasperi" OR "Elimia crenatella" OR "Elliptio chipolaensis" OR "Elliptio spinosa" OR "Elliptio steinstansana" OR "Elliptoideus sloatianus" OR "Empetrichthys latos" OR "Empidonax traillii extimus" OR "Enceliopsis nudicaulis" OR "Enhydra lutris kenyoni" OR "Enhydra lutris nereis" OR "Epicrates inornatus" OR "Epicrates monensis granti" OR "Epicrates monensis monensis" OR "Epioblasma brevidens" OR "Epioblasma capsaeformis" OR "Epioblasma florentina curtisii" OR "Epioblasma florentina florentina" OR "Epioblasma florentina walkeri" OR "Epioblasma metastriata" OR "Epioblasma obliquata obliquata" OR "Epioblasma obliquata perobliqua" OR "Epioblasma othcaloogensis" OR "Epioblasma penita" OR "Epioblasma torulosa gubernaculum" OR "Epioblasma torulosa rangiana" OR "Epioblasma torulosa torulosa" OR "Epioblasma triquetra" OR "Epioblasma turgidula" OR "Eragrostis fosbergii" OR "Eremalche kernensis" OR "Eremichthys acros" OR "Eretmochelys imbricata" OR "Eriastrum densifolium" OR "Erigeron decumbens" OR "Erigeron parishii" OR "Erigeron rhizomatus" OR "Erimonax monachus" OR "Erimystax cahni" OR "Erinna newcombi" OR "Eriodictyon altissimum" OR "Eriodictyon capitatum" OR "Eriogonum apricum" OR "Eriogonum gypsophilum" OR "Eriogonum kennedyi" OR "Eriogonum longifolium" OR "Eriogonum ovalifolium" OR "Eriogonum pelinophilum" OR "Eriophyllum latilobum" OR "Eryngium aristulatum" OR "Eryngium constancei" OR "Eryngium cuneifolium" OR "Erysimum capitatum" OR "Erysimum menziesii" OR "Erysimum teretifolium" OR "Erythronium propullans" OR "Etheostoma boschungi" OR "Etheostoma chermocki" OR "Etheostoma chienense" OR "Etheostoma etowahae" OR "Etheostoma fonticola" OR "Etheostoma moorei" OR "Etheostoma nianguae" OR "Etheostoma nuchale" OR "Etheostoma okaloosae" OR "Etheostoma percnurum" OR "Etheostoma phytophilum" OR "Etheostoma rubrum" OR "Etheostoma scotti" OR "Etheostoma sellare" OR "Etheostoma" OR "Etheostoma susanae" OR "Etheostoma wapiti" OR "Eubalaena glacialis" OR "Eubalaena japonica" OR "Eucyclogobius newberryi" OR "Eugenia haematocarpa" OR "Eugenia koolauensis" OR "Eugenia woodburyana" OR "Eumeces egregius lividus" OR "Eumetopias jubatus" OR "Euphilotes battoides allyni" OR "Euphilotes enoptes smithi" OR "Euphorbia haeleeleana" OR "Euphorbia telephioides" OR "Euphydryas editha bayensis" OR "Euphydryas editha quino" OR "Euphydryas editha wrighti" OR "Euproserpinus euterpe" OR "Eurycea nana" OR "Eurycea sosorum" OR "Eutrema penlandii" OR "Exocarpos luteolus" OR "Falco femoralis septentrionalis" OR "Flueggea neowawraea" OR "Frankenia johnstonii" OR "Fremontodendron californicum" OR "Fremontodendron mexicanum" OR "Fritillaria gentneri" OR "Fulica americana 
alai" OR "Fusconaia cor" OR "Fusconaia cuneolus" OR "Gahnia lanaiensis" OR "Galactia smallii" OR "Galium buxifolium" OR "Galium californicum" OR "Gallinula chloropus guami" OR "Gallinula chloropus sandvicensis" OR "Gambelia silus" OR "Gambusia gaigei" OR "Gambusia georgei" OR "Gambusia heterochir" OR "Gambusia nobilis" OR "Gammarus acherondytes" OR "Gammarus desperatus" OR "Gardenia brighamii" OR "Gardenia mannii" OR "Gasterosteus aculeatus williamsoni" OR "Gaura neomexicana" OR "Geocarpon minimum" OR "Geranium arboreum" OR "Geranium kauaiense" OR "Geranium multiflorum" OR "Gesneria pauciflora" OR "Geum radiatum" OR "Gila bicolor mohavensis" OR "Gila bicolor" OR "Gila boraxobius" OR "Gila cypha" OR "Gila ditaenia" OR "Gila elegans" OR "Gila intermedia" OR "Gila nigrescens" OR "Gila purpurea" OR "Gila robusta jordani" OR "Gila seminuda" OR "Gilia tenuiflora" OR "Gilia tenuiflora" OR "Glaucomys sabrinus coloratus" OR "Glaucomys sabrinus fuscus" OR "Glaucopsyche lygdamus palosverdesensis" OR "Goetzea elegans" OR "Gopherus agassizii" OR "Gopherus polyphemus" OR "Gouania hillebrandii" OR "Gouania meyenii" OR "Gouania vitifolia" OR "Graptemys flavimaculata" OR "Graptemys oculifera" OR "Grindelia fraxino-pratensis" OR "Grus americana" OR "Grus canadensis pulla" OR "Gymnoderma lineare" OR "Gymnogyps californianus" OR "Hackelia venusta" OR "Halcyon cinnamomina cinnamomina" OR "Haliotis cracherodii" OR "Haliotis sorenseni" OR "Halophila johnsonii" OR "Haplostachys haplostachya" OR "Harperocallis flava" OR "Harrisia portoricensis" OR "Hedeoma todsenii" OR "Hedyotis cookiana" OR "Hedyotis coriacea" OR "Hedyotis degeneri" OR "Hedyotis mannii" OR "Hedyotis parvula" OR "Hedyotis purpurea" OR "Hedyotis schlechtendahliana" OR "Hedyotis st.-johnii" OR "Helenium virginicum" OR "Helianthemum greenei" OR "Helianthus paradoxus" OR "Helianthus schweinitzii" OR "Helminthoglypta walkeriana" OR "Helonias bullata" OR "Hemignathus lucidus" OR "Hemignathus munroi" OR "Hemignathus procerus" OR "Hemistena lata" OR "Heraclides aristodemus ponceanus" OR "Herpailurus yagouaroundi cacomitli" OR "Herpailurus yagouaroundi tolteca" OR "Hesperia leonardus montana" OR "Hesperolinon congestum" OR "Hesperomannia arborescens" OR "Hesperomannia arbuscula" OR "Hesperomannia lydgatei" OR "Heterelmis comalensis" OR "Hexastylis naniflora" OR "Hibiscadelphus distans" OR "Hibiscadelphus giffardianus" OR "Hibiscadelphus hualalaiensis" OR "Hibiscadelphus woodii" OR "Hibiscus arnottianus" OR "Hibiscus brackenridgei" OR "Hibiscus clayi" OR "Hibiscus waimeae" OR "Himantopus mexicanus knudseni" OR "Hoffmannseggia tenella" OR "Holocarpha macradenia" OR "Howellia aquatilis" OR "Hudsonia montana" OR "Huperzia mannii" OR "Hybognathus amarus" OR "Hymenoxys herbacea" OR "Hymenoxys texana" OR "Hypericum cumulicola" OR "Hypomesus transpacificus" OR "Icaricia icarioides fenderi" OR "Icaricia icarioides missionensis" OR "Ictalurus pricei" OR "Ilex cookii" OR "Ilex sintenisii" OR "Iliamna corei" OR "Ipomopsis polyantha" OR "Ipomopsis sancti-spiritus" OR "Iris lacustris" OR "Ischaemum byrone" OR "Isodendrion hosakae" OR "Isodendrion laurifolium" OR "I sodendrion longifolium" OR "Isodendrion pyrifolium" OR "Isoetes louisianensis" OR "Isoetes melanospora" OR "Isoetes tegetiformans" OR "Isotria medeoloides" OR "Ivesia kingii" OR "Jacquemontia reclinata" OR "Juglans jamaicensis" OR "Justicia cooleyi" OR "Juturnia kosteri" OR "Kanaloa kahoolawensis" OR "Keysseria erici" OR "Keysseria helenae" OR Lagenifera OR "Kokia cookei" OR "Kokia drynarioides" OR "Kokia kauaiensis" OR "Labordia cyrtandrae" OR "Labordia helleri" OR "Labordia lydgatei" OR "Labordia pumila" OR "Labordia tinifolia" OR "Labordia triflora" OR "Lampsilis abrupta" OR "Lampsilis altilis" OR "Lampsilis 
higginsii" OR "Lampsilis perovalis" OR "Lampsilis powellii" OR "Lampsilis streckeri" OR "Lampsilis subangulata" OR "Lampsilis virescens" OR "Lanius ludovicianus mearnsi" OR Lanx OR "Lasiurus cinereus semotus" OR "Lasmigona decorata" OR "Lasthenia burkei" OR "Lasthenia conjugens" OR "Layia carnosa" OR "Leopardus pardalis" OR "Lepanthes eltoroensis" OR "Lepidium arbuscula" OR "Lepidium barnebyanum" OR "Lepidium papilliferum" OR "Lepidochelys kempii" OR "Lepidochelys olivacea" OR "Lepidomeda albivallis" OR "Lepidomeda mollispinis pratensis" OR "Lepidomeda vittata" OR "Lepidurus packardi" OR "Leptocereus grantianus" OR "Leptodea leptodon" OR "Leptoneta myopica" OR "Leptonycteris curasoae yerbabuenae" OR "Leptonycteris nivalis" OR "Leptoxis ampla" OR "Leptoxis foremani" OR "Leptoxis plicata" OR "Leptoxis taeniata" OR "Lepyrium showalteri" OR "Lespedeza leptostachya" OR "Lesquerella congesta" OR "Lesquerella kingii" OR "Lesquerella lyrata" OR "Lesquerella pallida" OR "Lesquerella perforata" OR "Lesquerella thamnophila" OR "Lesquerella tumulosa" OR "Lessingia germanorum" OR "Liatris helleri" OR "Liatris ohlingerae" OR "Lilaeopsis schaffneriana" OR "Lilium occidentale" OR "Lilium pardalinum" OR "Limnanthes floccosa" OR "Limnanthes vinculans" OR "Lindera melissifolia" OR "Lioplax cyclostomaformis" OR "Lipochaeta fauriei" OR "Lipochaeta kamolensis" OR "Lipochaeta lobata" OR "Lipochaeta micrantha" OR "Lipochaeta tenuifolia" OR "Lipochaeta venosa" OR "Lipochaeta waimeaensis" OR "Lirceus usdagalun" OR "Lithophragma maximum" OR "Lobelia gaudichaudii" OR "Lobelia monostachya" OR "Lobelia niihauensis" OR "Lobelia oahuensis" OR "Lomatium bradshawii" OR "Lomatium cookii" OR "Lotus dendroideus" OR "Loxioides bailleui" OR "Loxops caeruleirostris" OR "Loxops coccineus coccineus" OR "Loxops coccineus ochraceus" OR "Lupinus aridorum" OR "Lupinus nipomensis" OR "Lupinus sulphureus" OR "Lupinus tidestromii" OR "Lycaeides argyrognomon lotis" OR "Lycaeides melissa samuelis" OR "Lycopodium nutans" OR Phlegmariurus OR "Lynx canadensis" OR "Lyonia truncata" OR "Lysimachia asperulaefolia" OR "Lysimachia daphnoides" OR "Lysimachia filifolia" OR "Lysimachia iniki" OR "Lysimachia lydgatei" OR "Lysimachia maxima" OR "Lysimachia pendens" OR "Lysimachia scopulensis" OR "Lysimachia venosa" OR "Macbridea alba" OR "Malacothamnus clementinus" OR "Malacothamnus fasciculatus" OR "Malacothrix indecora" OR "Malacothrix squalida" OR "Manduca blackburni" OR "Manihot walkerae" OR "Margaritifera hembeli" OR "Mariscus fauriei" OR "Mariscus pennatiformis" OR "Marshallia mohrii" OR "Marsilea villosa" OR "Masticophis lateralis euryxanthus" OR "Meda fulgida" OR "Medionidus acutissimus" OR "Medionidus parvulus" OR "Medionidus simpsonianus" "Medionidus simpsonianus" OR "Megalagrion nesiotes" OR "Megalagrion pacificum" OR "Megapodius laperouse" OR "Megaptera novaeangliae" OR "Melamprosops phaeosoma" OR "Melicope adscendens" OR "Melicope balloui" OR "Melicope degeneri" OR "Melicope haupuensis" OR "Melicope knudsenii" OR "Melicope lydgatei" OR "Melicope mucronulata" OR "Melicope munroi" OR "Melicope ovalis" OR "Melicope pallida" OR "Melicope paniculata" OR "Melicope puberula" OR "Melicope quadrangularis" OR "Melicope reflexa" OR "Melicope saint-johnii" OR "Melicope zahlbruckneri" OR "Menidia extensa" OR "Mentzelia leucophylla" OR "Mesodon clarki nantahala" OR "Mesodon magazinensis" OR "Microhexura montivaga" OR "Microtus californicus scirpensis" OR "Microtus mexicanus hualpaiensis" OR "Microtus pennsylvanicus dukecampbelli" OR "Mimulus michiganensis" OR "Mirabilis macfarlanei" OR "Mitracarpus maxwelliae" OR "Mitracarpus polycladus" OR "Moapa coriacea" OR "Moho braccatus" OR "Monachus schauinslandi" OR "Monardella linoides" OR "Monolopia congdonii" OR 
Lembertia OR "Munroidendron racemosum" OR "Mustela nigripes" OR "Myadestes lanaiensis rutha" OR "Myadestes myadestinus" OR "Myadestes palmeri" OR "Mycteria americana" OR "Myotis grisescens" OR "Myotis sodalis" OR "Myrcia paganii" OR "Myrsine juddii" OR "Myrsine knudsenii" OR "Myrsine linearifolia" OR "Myrsine mezii" OR "Navarretia fossalis" OR "Navarretia leucocephala" OR "Neoleptoneta microps" OR "Neonympha mitchellii francisci" OR "Neonympha mitchellii mitchellii" OR "Neoseps reynoldsi" OR "Neostapfia colusana" OR "Neotoma floridana smalli" OR "Neotoma fuscipes riparia" OR "Neraudia angulata" OR "Neraudia ovata" OR "Neraudia sericea" OR "Nerodia clarkii taeniata" OR "Nerodia erythrogaster neglecta" OR "Nesogenes rotensis" OR "Nicrophorus americanus" OR "Nitrophila mohavensis" OR "Nolina brittoniana" OR "Nothocestrum breviflorum" OR "Nothocestrum peltatum" OR "Nototrichium humile" OR "Notropis albizonatus" OR "Notropis cahabae" OR "Notropis girardi" OR "Notropis mekistocholas" OR "Notropis simus pecosensis" OR "Notropis topeka" OR "Notropis tristis" OR "Noturus baileyi" OR "Noturus crypticus" OR "Noturus flavipinnis" OR "Noturus placidus" OR "Noturus stanauli" OR "Noturus trautmani" OR "Numenius borealis" OR "Obovaria retusa" OR "Ochrosia kilaueaensis" OR "Odocoileus virginianus clavium" OR "Odocoileus virginianus leucurus" OR "Oenothera avita" OR "Oenothera deltoides" OR "Oncorhynchus keta" OR "Oncorhynchus kisutch" OR "Oncorhynchus mykiss" OR "Oncorhynchus nerka" OR "Oncorhynchus tshawytscha" OR "Oncorhynchus aguabonita whitei" OR "Oncorhynchus apache" OR "Oncorhynchus clarki henshawi" OR "Oncorhynchus clarki seleniris" OR "Oncorhynchus clarki stomias" OR "Oncorhynchus gilae" OR "Opuntia treleasei" OR "Orcinus orca" OR "Orconectes shoupi" OR "Orcuttia californica" OR "Orcuttia inaequalis" OR "Orcuttia pilosa" OR "Orcuttia tenuis" OR "Orcuttia viscida" OR "Oregonichthys crameri" OR "Oreomystis bairdi" OR "Oreomystis mana" OR "Orthalicus reses" OR "Oryzomys palustris natator" OR "Osmoxylon mariannense" OR "Ottoschulzia rhodoxylon" OR "Ovis canadensis nelsoni" OR "Ovis canadensis sierrae" OR "Oxyloma haydeni kanabensis" OR "Oxypolis canbyi" OR "Oxytheca parishii" OR "Oxytropis campestris" OR "Pacifastacus fortis" OR "Palaemonetes cummingi" OR "Palaemonias alabamae" OR "Palaemonias ganteri" OR "Palmeria dolei" OR "Panicum fauriei" OR "Panicum niihauense" OR "Panthera onca" OR "Paronychia chartacea" OR "Paroreomyza flammea" OR "Paroreomyza maculata" OR "Parvisedum leiocarpum" OR "Pedicularis furbishiae" OR "Pediocactus sileri" OR "Pediocactus bradyi" OR "Pediocactus despainii" OR "Pediocactus knowltonii" OR "Pediocactus peeblesianus" OR "Pediocactus winkleri" OR "Pegias fabula" OR "Peltophryne lemur" OR "Penstemon debilis" OR "Penstemon haydenii" OR "Penstemon penlandii" OR "Pentachaeta bellidiflora" OR "Pentachaeta Iyonii" OR "Peperomia wheeleri" OR "Percina antesella" OR "Percina aurolineata" OR "Percina jenkinsi" OR "Percina pantherina" OR "Percina rex" OR "Percina tanasi" OR "Perognathus longimembris pacificus" OR "Peromyscus gossypinus allapaticola" OR "Peromyscus polionotus allophrys" OR "Peromyscus polionotus ammobates" OR "Peromyscus polionotus niveiventris" OR "Peromyscus polionotus peninsularis" OR "Peromyscus polionotus phasma" OR "Peromyscus polionotus trissyllepsis" OR "Peucedanum sandwicense" OR "Phacelia argillacea" OR "Phacelia formosula" OR "Phacelia insularis" OR "Phacelia submutica" OR "Phaeognathus hubrichti" OR "Phlox hirsuta" OR "Phlox nivalis" OR "Phoca largha" OR "Phoebastria albatrus" OR "Phoxinus cumberlandensis" OR "Phoxinus saylori" OR "Phyllostegia glabra" OR "Phyllostegia hirsuta" OR "Phyllostegia hispida" OR "Phyllostegia kaalaensis" OR "Phyllostegia knudsenii" OR 
"Phyllostegia mannii" OR "Phyllostegia mollis" OR "Phyllostegia parviflora" OR "Phyllostegia racemosa" OR "Phyllostegia renovans" OR "Phyllostegia velutina" OR "Phyllostegia waimeae" OR "Phyllostegia warshaueri" OR "Phyllostegia wawrana" OR "Physa natricina" OR "Physaria filiformis" OR "Physaria obcordata" OR "Physeter catodon" OR "Picoides borealis" OR "Pilosocereus robinii" OR "Pinguicula ionantha" OR "Piperia yadonii" OR "Pipilo crissalis eremophilus" OR "Pittosporum napaliense" OR "Pityopsis ruthii" OR "Plagiobothrys hirtus" OR "Plagiobothrys strictus" OR "Plagopterus argentissimus" OR "Plantago hawaiensis" OR "Plantago princeps" OR "Platanthera holochila" OR "Platanthera leucophaea" OR "Platanthera praeclara" OR "Platydesma rostrata" OR "Pleodendron macranthum" OR "Pleomele hawaiiensis" OR "Plethobasus cicatricosus" OR "Plethobasus cooperianus" OR "Plethobasus cyphyus" OR "Plethodon nettingi" OR "Plethodon shenandoah" OR "Pleurobema clava" OR "Pleurobema collina" OR "Pleurobema curtum" OR "Pleurobema decisum" OR "Pleurobema furvum" OR "Pleurobema georgianum" OR "Pleurobema gibberum" OR "Pleurobema hanleyianum" OR "Pleurobema marshalli" OR "Pleurobema perovatum" OR "Pleurobema plenum" OR "Pleurobema pyriforme" OR "Pleurobema taitianum" OR "Pleurocera foremani" OR "Poa atropurpurea" OR "Poa mannii" OR "Poa napensis" OR "Poa sandvicensis" OR "Poa siphonoglossa" OR "Poeciliopsis occidentalis" OR "Pogogyne abramsii" OR "Pogogyne nudiuscula" OR "Polioptila californica californica" OR "Polyborus plancus audubonii" OR "Polygala lewtonii" OR "Polygala smallii" OR "Polygonella basiramia" OR "Polygonella myriophylla" OR "Polygonum hickmanii" OR "Polygyriscus virginianus" OR "Polyphylla barbata" OR "Polystichum aleuticum" OR "Polystichum calderonense" OR "Polysticta stelleri" OR "Portulaca sclerocarpa" OR "Potamilus capax" OR "Potamilus inflatus" OR "Potamogeton clystocarpus" OR "Potentilla hickmanii" OR "Primula maguirei" OR "Pristis pectinata" OR "Pritchardia affinis" OR "Pritchardia aylmer-robinsonii" OR "Pritchardia hardyi" OR "Pritchardia kaalae" OR "Pritchardia munroi" OR "Pritchardia napaliensis" OR "Pritchardia remota" OR "Pritchardia schattaueri" OR "Pritchardia viscosa" OR "Prunus geniculata" OR "Pseudemys alabamensis" OR "Pseudemys rubriventris bangsi" OR "Pseudobahia bahiifolia" OR "Pseudobahia peirsonii" OR "Pseudocopaeodes eunus obscurus" OR "Pseudonestor xanthophrys" OR "Psittirostra psittacea" OR "Psychotria grandiflora" OR "Psychotria hobdyi" OR "Pteralyxia kauaiensis" OR "Pteris lidgatei" OR "Pterodroma phaeopygia sandwichensis" OR "Pteropus mariannus mariannus" OR "Pteropus tokudae" OR "Ptilimnium nodosum" OR "Ptychobranchus greenii" OR "Ptychocheilus lucius" OR "Puffinus auricularis newelli" OR "Puffinus heinrothi" OR "Puma concolor" OR "Puma concolor coryi" OR "Puma concolor couguar" OR "Purshia subintegra" OR "Pyrgulopsis pachyta" OR "Pyrgulopsis bruneauensis" OR "Pyrgulopsis neomexicana" OR "Pyrgulopsis ogmorhaphe" OR "Pyrgulopsis roswellensis" OR "Pyrgus ruralis lagunae" OR "Quadrula cylindrica strigillata" OR "Quadrula fragosa" OR "Quadrula intermedia" OR "Quadrula sparsa" OR "Quadrula stapes" OR "Quercus hinckleyi" OR "Rallus longirostris levipes" OR "Rallus longirostris obsoletus" OR "Rallus longirostris yumanensis" OR "Rallus owstoni" OR "Rana capito sevosa" OR "Rana chiricahuensis" OR "Rana draytonii" OR "Rana muscosa" OR "Rangifer tarandus caribou" OR "Ranunculus aestivalis" OR "Ranunculus acriformis"OR "Reithrodontomys raviventris" OR "Remya kauaiensis" OR "Remya mauiensis" OR "Remya montgomeryi" OR "Rhadine exilis" OR "Rhadine infernalis" OR "Rhadine persephone" OR "Rhaphiomidas terminatus abdominalis" OR "Rhinichthys osculus lethoporus" OR "Rhinichthys 
osculus nevadensis" OR "Rhinichthys osculus oligoporus" OR "Rhinichthys osculus" OR "Rhinichthys osculus thermalis" OR "Rhodiola integrifolia" OR "Rhododendron chapmanii" OR "Rhus michauxii" OR "Rhynchospora knieskernii" OR "Ribes echinellum" OR "Rorippa gambellii" OR "Rostrhamus sociabilis plumbeus" OR "Sagittaria fasciculata" OR "Sagittaria secundifolia" OR "Salmo salar" OR "Salvelinus confluentus" OR "Sanicula mariversa" OR "Sanicula purpurea" OR "Santalum freycinetianum" OR "Sarracenia oreophila" OR "Sarracenia rubra alabamensis" OR "Sarracenia rubra" OR "Scaevola coriacea" OR "Scaphirhynchus albus" OR "Scaphirhynchus platorynchus" OR "Scaphirhynchus suttkusi" OR "Schiedea adamantis" OR "Schiedea apokremnos" OR "Schiedea attenuata" OR "Schiedea haleakalensis" OR "Schiedea helleri" OR "Shiedea hookeri" OR "Schiedea kaalae" OR "Schiedea kauaiensis" OR "Schiedea kealiae" OR "Schiedea Iydgatei" OR "Schiedea membranacea" OR "Schiedea nuttallii" OR "Schiedea sarmentosa" OR "Schiedea spergulina" OR "Schiedea stellarioides" OR "Schiedea verticillata" OR "Schoenocrambe argillacea" OR "Schoenocrambe barnebyi" OR "Schoenocrambe suffrutescens" OR "Schoepfia arenaria" OR "Schwalbea americana" OR "Scirpus ancistrochaetus" OR "Sciurus niger cinereus" OR "Sclerocactus brevispinus" OR "Sclerocactus glaucus" OR "Sclerocactus mesae-verdae" OR "Sclerocactus wetlandicus" OR "Sclerocactus wrightiae" OR "Scutellaria floridana" OR "Scutellaria montana" OR "Sebastes paucispinis" OR "Sebastes pinniger" OR "Sebastes ruberrimus" OR "Senecio franciscanus" OR "Senecio layneae" OR "Serianthes nelsonii" OR "Sesbania tomentosa" OR "Sibara filifolia" OR "Sicyos alba" OR "Sidalcea keckii" OR "Sidalcea nelsoniana" OR "Sidalcea oregana" OR "Sidalcea pedata" OR "Silene alexandri" OR "Silene hawaiiensis" OR "Silene lanceolata" OR "Silene perlmanii" OR "Silene polypetala" OR "Silene spaldingii" OR "Sisyrinchium dichotomum" OR "Solanum drymophilum" OR "Solanum incompletum" OR "Solanum sandwicense" OR "Solidago albopilosa" OR "Solidago houghtonii" OR "Solidago shortii" OR "Solidago spithamaea" OR "Somateria fischeri" OR "Somatochlora hineana" OR "Sorex ornatus relictus" OR "Spelaeorchestia koloana" OR "Speoplatyrhinus poulsoni" OR "Spermolepis hawaiiensis" OR "Spermophilus brunneus brunneus" OR "Speyeria callippe callippe" OR "Speyeria zerene behrensii" OR "Speyeria zerene hippolyta" OR "Speyeria zerene myrtleae" OR "Sphaerodactylus micropithecus" OR "Spigelia gentianoides" OR "Spiraea virginiana" OR "Spiranthes delitescens" OR "Spiranthes diluvialis" OR "Spiranthes parksii" OR "Stahlia monosperma" OR "Stenogyne angustifolia angustifolia" OR "Stenogyne bifida" OR "Stenogyne campanulata" OR "Stenogyne kanehoana" OR "Stenogyne kealiae" OR "Stephanomeria malheurensis" OR "Sterna antillarum" OR "Sterna dougallii dougallii" OR "Sternotherus depressus" OR "Streptanthus albidus" OR "Streptanthus niger" OR "Streptocephalus woottoni" OR "Strix occidentalis caurina" OR "Strix occidentalis lucida" OR "Stygobromus pecki" OR "Stygobromus hayi" OR "Stygoparnus comalensis" OR "Styrax portoricensis" OR "Styrax texanus" OR "Suaeda californica" OR "Succinea chittenangoensis" OR "Swallenia alexandrae" OR "Sylvilagus bachmani riparius" OR "Sylvilagus palustris hefneri" OR "Syncaris pacifica" OR "Tamiasciurus hudsonicus grahamensis" OR "Taraxacum californicum" OR "Tartarocreagris texana" OR "Taylorconcha serpenticola" OR "Tectaria estremerana" OR "Telespyza cantans" OR "Telespyza ultima" OR "Ternstroemia luquillensis" OR "Ternstroemia subsessilis" OR "Tetramolopium arenarium" OR "Tetramolopium capillare" OR "Tetramolopium filiforme" OR "Tetramolopium lepidotum" OR "Tetramolopium remyi" OR "Tetramolopium rockii" OR "Tetraplasandra bisattenuata" OR 
"Tetraplasandra flynnii" OR "Tetraplasandra gymnocarpa" OR "Texamaurops reddelli" OR "Texella cokendolpheri" OR "Texella reddelli" OR "Texella reyesi" OR "Thaleichthys pacificus" OR "Thalictrum cooleyi" OR "Thamnophis gigas" OR "Thamnophis sirtalis tetrataenia" OR "Thelypodium howellii spectabilis" OR "Thelypodium stenopetalum" OR "Thelypteris inabonensis" OR "Thelypteris pilosa" OR "Thelypteris verecunda" OR "Thelypteris yaucoensis" OR "Thermosphaeroma thermophilus" OR "Thlaspi californicum" OR "Thymophylla tephroleuca" OR "Thysanocarpus conchuliferus" OR "Tiaroga cobitis" OR "Torreya taxifolia" OR "Townsendia aprica" OR "Toxolasma cylindrellus" OR "Trematolobelia singularis" OR "Trichechus manatus" OR "Trichilia triacantha" OR "Trichostema austromontanum" OR "Trifolium amoenum" OR "Trifolium stoloniferum" OR "Trifolium trichocalyx" OR "Trillium persistens" OR "Trillium reliquum" OR "Trimerotropis infantilis" OR "Triodopsis platysayoides" OR "Tryonia alamosae" OR "Tuctoria greenei" OR "Tuctoria mucronata" OR "Tulotoma magnifica" OR "Tympanuchus cupido attwateri" OR "Typhlomolge rathbuni" OR "Uma inornata" OR "Urera kaalae" OR "Urocyon littoralis catalinae" OR "Urocyon littoralis littoralis" OR "Urocyon littoralis santacruzae" OR "Urocyon littoralis santarosae" OR "Ursus americanus" OR "Ursus americanus luteolus" OR "Ursus arctos horribilis" OR "Ursus maritimus" OR "Verbena californica" OR "Verbesina dissita" OR "Vermivora bachmanii" OR "Vernonia proctorii" OR "Vicia menziesii" OR "Vigna o-wahuensis" OR "Villosa fabalis" OR "Villosa perpurpurea" OR "Villosa trabalis" OR "Viola chamissoniana" OR "Viola helenae" OR "Viola kauaiensis" OR "Viola lanaiensis" OR "Viola oahuensis" OR "Vireo atricapilla" OR "Vireo bellii pusillus" OR "Vulpes macrotis mutica" OR "Warea amplexifolia" OR "Warea carteri" OR "Wilkesia hobdyi" OR "Xantusia riversiana" OR "Xylosma crenatum" OR "Xyrauchen texanus" OR "Xyris tennesseensis" OR "Yermo xanthocephalus" OR "Zanthoxylum dipetalum" OR "Zanthoxylum hawaiiense" OR "Zanthoxylum thomasianum" OR "Zapus hudsonius preblei" OR "Zizania texana" OR "Ziziphus celata" OR "Zosterops conspicillatus conspicillatus" OR "Zosterops rotensis"

\subsection{Search string for listed US Candidate Species (from US Fish and Wildlife Service (http://ecos.fws.gov/tess_public/pub/candidateSpecies.jsp)):}

("invasive species" OR "invasive alien species" OR IAS OR feral OR "introduced species" OR "non-indigenous" OR alien OR "invasive plant" OR "invasive weed" OR exotic OR "non-native") AND "Aborimus longicaudus" OR "Abronia alpina" OR "Agave eggersiana" OR "Amazona viridigenalis" OR "Ambrysus funebris" OR "Anaea troglodyta floridalis" OR "Anaxyrus canorus" OR "Anthus spragueii" OR "Arabis georgiana" OR "Argythamnia blodgettii" OR "Artemisia borealis" OR "Astragalus anserinus" OR "Astragalus cusickii" OR "Astragalus microcymbus" OR "Astragalus schmolliae" OR "Astragalus tortipes" OR "Atlantea tulita" OR "Bidens campylotheca pentamera" OR "Bidens campylotheca waihoiensis" OR "Bidens conjuncta" OR "Bidens micrantha ctenophylla" OR "Boechera pusilla" OR "Brachyramphus brevirostris" OR "Brickellia mosieri" OR "Calamagrostis expansa" OR "Calamagrostis hillebrandii" OR "Calidris canutus rufa" OR "Calochortus persistens" OR "Canavalia pubescens" OR "Castilleja christii" OR "Catostomus discobolus yarrowi" OR "Centrocercus minimus" OR "Centrocercus urophasianus" OR "Chamaecrista lineata keyensis" OR "Chamaesyce deltoidea pinetorum" OR "Chamaesyce deltoidea serpyllum" OR "Chionactis occipitalis klauberi" or "Chorizanthe parryi" or "Chromolaena frustrata" or "Cicindela albissima" OR "Cicindela highlandensis" OR "Cicurina wartoni" OR "Cirsium 
wrightii" OR "Coccyzus americanus" OR "Cochliopa texana" OR "Consolea corallicola" OR "Cordia rupicola" OR Cottus OR "Crystallaria cincotta" OR "Cyanea asplenifolia" OR "Cyanea kunthiana" OR "Cyanea obtusa" OR "Cyanea tritomantha" OR "Cyclosorus boydiae" OR "Cynomys gunnisoni" OR "Cyrtandra filipes" OR "Cyrtandra oxybapha" OR "Dalea carthagenensis floridana" OR "Dendroica angelae" OR "Dichanthelium hirstii" OR "Digitaria pauciflora" OR "Drosophila digressa" OR "Echinomastus erectocentrus" OR "Elimia melanoides" OR "Emballonura semicaudata rotensis" OR "Emballonura semicaudata semicaudata" OR "Eremophila alpestris strigata" OR "Erigeron lemmonii" OR "Eriogonum codium" OR "Eriogonum corymbosum" OR "Eriogonum diatomaceum" OR "Eriogonum kelloggii" OR "Eriogonum soredium" OR "Etheostoma cragini" OR "Etheostoma sagitta" OR "Eua zebrina" OR "Eumops floridanus" OR "Euphydryas editha taylori" OR "Eurycea chisholmensis" OR "Eurycea naufragia" OR "Eurycea tonkawae" OR "Eurycea waterlooensis" OR "Festuca hawaiiensis" OR "Festuca ligulata" OR "Gallicolumba stairi" OR "Gammarus hyalleloides" OR "Gardenia remyi" OR "Gavia adamsii" OR "Geranium hanaense" OR "Geranium hillebrandii" OR "Gila nigra" OR "Gila robusta" OR "Glyphopsyche sequatchie" OR "Gonocalyx concolor" OR "Gopherus agassizii" OR "Gopherus polyphemus" OR "Gulo gulo luscus" OR "Gyrinophilus gulolineatus" OR "Harrisia aboriginum" Cereus OR "Hazardia orcuttii" OR "Hedyotis fluviatilis" OR "Helianthus verticillatus" OR "Hesperia dacotae" OR "Heterelmis stephani" OR "Hibiscus dasycalyx" OR "Huperzia stemmermanniae" OR Phlegmariurus OR "Hyla wrightorum" OR "Hylaeus anthracinus" OR "Hylaeus assimulans" OR "Hylaeus facilis" OR "Hylaeus hilaris" OR "Hylaeus kuakea" OR "Hylaeus longiceps" OR "Hylaeus mana" OR "Hypolimnas octocula mariannensis" OR "Iotichthys phlegethontis" OR "Ivesia webberi" OR "Joinvillea ascendens ascendens" OR "Kinosternon sonoriense longifemorale" OR "Lampsilis bracteata" OR "Lampsilis rafinesqueana" OR "Leavenworthia crassa" OR "Leavenworthia exigua laciniata" OR "Leavenworthia texana" OR "Lednia tumana" OR "Lepidium ostleri" OR "Lexingtonia dolabelloides" OR "Linum arenicola" OR "Linum carteri carteri" OR "Lithobates onca" OR "Lycaena hermes" OR "Lynx canadensis" OR "Martes pennanti" OR "Megalagrion xanthomelas" OR "Metabetaeus lohena" OR "Microlepia strigosa" OR "Mimulus fremontii" OR Moxostoma OR "Myrsine fosbergii" OR "Myrsine vaccinioides" OR "Narthecium americanum" OR "Necturus alabamensis" OR "Newcombia cumingi" OR "Nothocestrum latifolium" OR "Notophthalmus perstriatus" OR "Notropis buccula" OR "Notropis oxyrhynchus" OR "Oarisma poweshiek" OR "Oceanodroma castro" OR "Ochrosia haleakalae" OR "Odobenus rosmarus" OR "Oncorhynchus clarki virginalis" OR "Ostodes strigatus" OR "Palaemonella burnsi" OR "Partula gibba" OR "Partula langfordi" OR "Partula radiolata" OR "Partulina semicarinata" OR "Partulina variabilis" OR "Pediocactus peeblesianus fickeiseniae" OR "Penstemon scariosus albifluvis" OR "Peperomia subpetiolata" OR "Percina aurora" OR "Phacelia stellaris" OR "Phyllostegia bracteata" OR "Phyllostegia floribunda" OR "Physaria douglasii tuplashensis" OR "Physaria globosa" OR "Pinus albicaulis" OR "Pituophis melanoleucus lodingi" OR "Pituophis ruthveni" OR "Planorbella magnifica" OR "Platanthera integrilabia" OR "Platydesma remyi" OR "Plebejus shasta charlestonensis" OR "Pleomele fernaldii" OR "Plethodon neomexicanus" OR "Polites mardon" OR "Popenaias popei" OR "Porzana tabuensis" OR "Potentilla basaltica" OR "Procaris hawaiana" OR "Pseudanophthalmus caecus" OR "Pseudanophthalmus colemanensis" OR "Pseudanophthalmus fowlerae" OR "Pseudanophthalmus frigidus" OR "Pseudanophthalmus inquisitor" OR 
"Pseudanophthalmus insularis" OR "Pseudanophthalmus parvus" OR "Pseudanophthalmus paulus" OR "Pseudanophthalmus tiresias" OR "Pseudanophthalmus troglodytes" OR "Pseudognaphalium sandwicensium" OR Gnaphalium OR "Pseudotryonia adamantina" OR Tryonia OR "Ptychobranchus subtentum" OR "Pyrgulopsis morrisoni" OR "Pyrgulopsis notidicola" OR "Pyrgulopsis thompsoni" OR "Quadrula aurea" OR "Quadrula cylindrica cylindrica" OR "Quadrula houstonensis" OR "Quadrula petrina" OR "Rana luteiventris" OR "Rana muscosa" OR "Rana pretiosa" OR "Ranunculus hawaiensis" OR "Ranunculus mauiensis" OR "Rorippa subumbellata" OR "Samoana fragilis" OR "Schiedea pubescens" OR "Schiedea salicaria" OR "Sedum eastwoodiae" OR "Sicyos macrophyllus" OR "Sideroxylon reclinatum" OR "Sistrurus catenatus" OR "Solanum conocarpum" OR "Solanum nelsonii" OR "Solidago plumosa" OR "Sonorella rosemontensis" OR "Spermophilus brunneus endemicus" OR "Sphaeralcea gierischii" OR "Stenogyne cranwelliae" OR "Streptanthus bracteatus" OR "Strymon acis bartrami" OR "Stygobromus kenki" OR "Sylvilagus transitionalis" OR "Symphyotrichum georgianum" OR "Synthliboramphus hypoleucus" OR "Thamnophis eques megalops" OR "Thomomys mazama glacialis" OR "Thomomys mazama louiei" OR "Thomomys mazama melanops" OR "Thomomys mazama pugetensis" OR "Thomomys mazama" OR "Thomomys mazama tacomensis" OR "Thomomys mazama tumuli" OR "Thomomys mazama yelmensis" OR "Thymallus arcticus" OR "Trichomanes punctatum" OR "Trifolium friscanum" OR "Truncilla macrodon" OR "Tryonia cheatumi" OR "Tryonia circumstriata" OR stocktonensis OR "Tympanuchus pallidicinctus" OR "Urocitellus washingtoni" OR "Vagrans egistina" OR "Vetericaris chaceorum" OR "Zapus hudsonius luteus" 
Appendix Two: Quality coding tool

\begin{tabular}{|c|c|c|c|}
\hline $\begin{array}{c}\text { Generic data } \\
\text { quality } \\
\text { features }\end{array}$ & Specific data quality features & Quality element & $\begin{array}{l}\text { Quality } \\
\text { score }\end{array}$ \\
\hline \multirow{5}{*}{$\begin{array}{l}\text { Internal } \\
\text { validity of } \\
\text { study }\end{array}$} & \multirow{5}{*}{ N/A } & Clear aims & 2 \\
\hline & & $\begin{array}{l}\text { Treatment and control groups similar at } \\
\text { start of trial (low heterogeneity } \\
\text { between locations, size of exp. areas, } \\
\text { soil type, shading, plant types etc.) }\end{array}$ & 2 \\
\hline & & $\begin{array}{l}\text { Outcomes measured accurately and } \\
\text { reliably }\end{array}$ & 2 \\
\hline & & Control of confounding variables & 2 \\
\hline & & Replications of study & 2 \\
\hline \multirow[t]{8}{*}{ Study Design } & \multirow[t]{8}{*}{ N/A } & $\begin{array}{l}\text { Randomised block design time series } \\
\text { (pre-intervention data/observations) }\end{array}$ & 80 \\
\hline & & $\begin{array}{l}\text { Non-randomised block design time } \\
\text { series }\end{array}$ & 60 \\
\hline & & $\begin{array}{l}\text { Historical dataset e.g. >10 years (not } \\
\text { from current experimental observation) }\end{array}$ & 50 \\
\hline & & Site comparisons & 50 \\
\hline & & No site comparison & 30 \\
\hline & & Data without comparator & 30 \\
\hline & & Descriptive, field observations & 20 \\
\hline & & Expert opinion & 10 \\
\hline \multirow[t]{2}{*}{$\begin{array}{l}\text { Measurement } \\
\text { of outcomes }\end{array}$} & $\begin{array}{l}\text { Quantitative measurements of } \\
\text { intervention }\end{array}$ & $\begin{array}{l}\text { Population size, range, density, } \\
\text { fecundity-pop. counts/mark- } \\
\text { recapture/nest counts/dropping counts }\end{array}$ & 10 \\
\hline & $\begin{array}{l}\text { Qualitative/descriptive } \\
\text { observations of intervention } \\
\text { (e.g. vague estimate of time } \\
\text { since introduction) }\end{array}$ & $\begin{array}{l}\text { Population size, range, density, } \\
\text { fecundity }\end{array}$ & 5 \\
\hline
\end{tabular}




\begin{tabular}{|c|c|c|c|c|c|c|c|c|}
\hline Invasive Species & $\begin{array}{l}\text { Threatened } \\
\text { Species }\end{array}$ & $\begin{array}{l}\text { Level of } \\
\text { threat }\end{array}$ & $\begin{array}{l}\text { Direction } \\
\text { of Impact }\end{array}$ & Mechanism & Location & Study design & $\begin{array}{l}\text { Study } \\
\text { design } \\
\text { score }\end{array}$ & Reference \\
\hline $\begin{array}{l}\text { Amblycera } \\
\text { chewing lice } \\
\text { (unknown sp.) }\end{array}$ & $\begin{array}{l}\text { Loxops coccineus } \\
\text { coccineus }\end{array}$ & Endangered & Negative & Parasitism & US, Hawaii & Time-series & 77 & $\begin{array}{l}\text { Freed et al. } \\
\text { (2008) }\end{array}$ \\
\hline $\begin{array}{l}\text { Ambystoma } \\
\text { tigrinum } \\
\text { mavortium }\end{array}$ & $\begin{array}{l}\text { Ambystoma } \\
\text { californiense }\end{array}$ & Threatened & Positive & Hybridisation & $\begin{array}{l}\text { US, } \\
\text { California }\end{array}$ & $\begin{array}{l}\text { Observation } \\
\text { experimenta } \\
\text { I }\end{array}$ & 75 & $\begin{array}{l}\text { Fitzpatrick et al. } \\
\text { (2010) }\end{array}$ \\
\hline $\begin{array}{l}\text { Ambystoma } \\
\text { tigrinum } \\
\text { mavortium }\end{array}$ & $\begin{array}{l}\text { Ambystoma } \\
\text { californiense }\end{array}$ & Endangered & Negative & Predation & $\begin{array}{l}\text { US, } \\
\text { California }\end{array}$ & $\mathrm{BACl}$ & 79 & $\begin{array}{l}\text { Ryan et al. } \\
\text { (2009) }\end{array}$ \\
\hline Ameiurus melas & $\begin{array}{l}\text { Ambystoma } \\
\text { tigrinum stebbinsi }\end{array}$ & Endangered & Negative & & US, Arizona & $\begin{array}{l}\text { Interrupted } \\
\text { time-series }\end{array}$ & 61 & $\begin{array}{l}\text { Maret et al. } \\
(2006)\end{array}$ \\
\hline
\end{tabular}




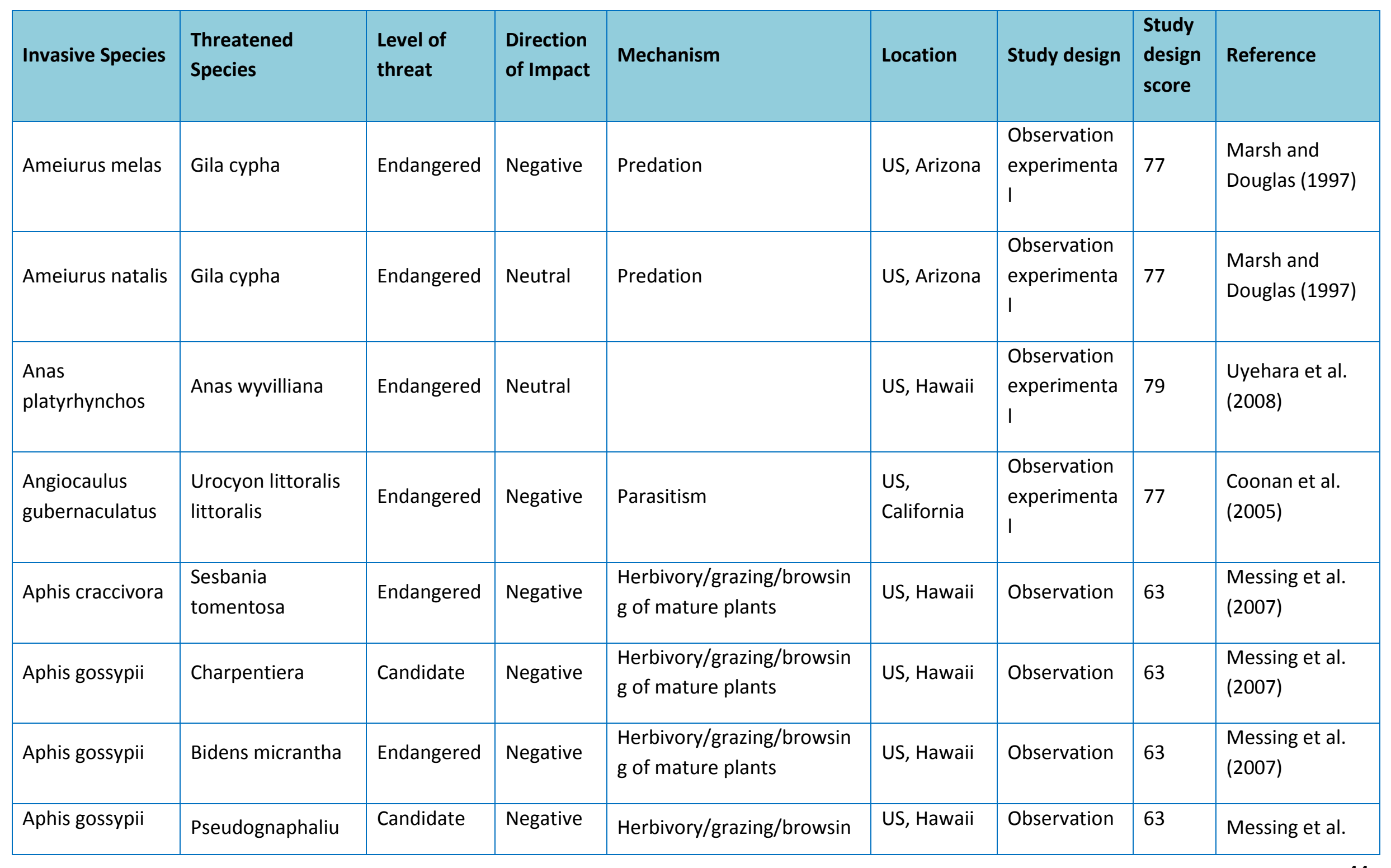




\begin{tabular}{|c|c|c|c|c|c|c|c|c|}
\hline Invasive Species & $\begin{array}{l}\text { Threatened } \\
\text { Species }\end{array}$ & $\begin{array}{l}\text { Level of } \\
\text { threat }\end{array}$ & $\begin{array}{l}\text { Direction } \\
\text { of Impact }\end{array}$ & Mechanism & Location & Study design & $\begin{array}{l}\text { Study } \\
\text { design } \\
\text { score }\end{array}$ & Reference \\
\hline Aphis gossypii & Chamaesyce & Endangered & Negative & $\begin{array}{l}\text { Herbivory/grazing/browsin } \\
\text { g of mature plants }\end{array}$ & US, Hawaii & Observation & 63 & $\begin{array}{l}\text { Messing et al. } \\
\text { (2007) }\end{array}$ \\
\hline Aphis gossypii & Abutilon menziesii & Endangered & Negative & $\begin{array}{l}\text { Herbivory/grazing/browsin } \\
\mathrm{g} \text { of mature plants }\end{array}$ & US, Hawaii & Observation & 63 & $\begin{array}{l}\text { Messing et al. } \\
\text { (2007) }\end{array}$ \\
\hline Aphis gossypii & $\begin{array}{l}\text { Hibiscus } \\
\text { arnottianus }\end{array}$ & Endangered & Negative & $\begin{array}{l}\text { Herbivory/grazing/browsin } \\
\mathrm{g} \text { of mature plants }\end{array}$ & US, Hawaii & Observation & 63 & $\begin{array}{l}\text { Messing et al. } \\
(2007)\end{array}$ \\
\hline Aphis gossypii & Hibiscus clayi & Endangered & Negative & $\begin{array}{l}\text { Herbivory/grazing/browsin } \\
\mathrm{g} \text { of mature plants }\end{array}$ & US, Hawaii & Observation & 63 & $\begin{array}{l}\text { Messing et al. } \\
(2007)\end{array}$ \\
\hline Aphis gossypii & Kokia drynarioides & Endangered & Negative & $\begin{array}{l}\text { Herbivory/grazing/browsin } \\
\mathrm{g} \text { of mature plants }\end{array}$ & US, Hawaii & Observation & 63 & $\begin{array}{l}\text { Messing, et al. } \\
\text { (2007) }\end{array}$ \\
\hline Aphis gossypii & $\begin{array}{l}\text { Gardenia } \\
\text { brighamii }\end{array}$ & Endangered & Negative & $\begin{array}{l}\text { Herbivory/grazing/browsin } \\
\mathrm{g} \text { of mature plants }\end{array}$ & US, Hawaii & Observation & 63 & $\begin{array}{l}\text { Messing et al. } \\
\text { (2007) }\end{array}$ \\
\hline
\end{tabular}




\begin{tabular}{|c|c|c|c|c|c|c|c|c|}
\hline Invasive Species & $\begin{array}{l}\text { Threatened } \\
\text { Species }\end{array}$ & $\begin{array}{l}\text { Level of } \\
\text { threat }\end{array}$ & $\begin{array}{l}\text { Direction } \\
\text { of Impact }\end{array}$ & Mechanism & Location & Study design & $\begin{array}{l}\text { Study } \\
\text { design } \\
\text { score }\end{array}$ & Reference \\
\hline Aphis spiraecola & $\begin{array}{l}\text { Munroidendron } \\
\text { racemosum }\end{array}$ & Endangered & Negative & $\begin{array}{l}\text { Herbivory/grazing/browsin } \\
\text { g of mature plants }\end{array}$ & US, Hawaii & Observation & 63 & $\begin{array}{l}\text { Messing et al. } \\
(2007)\end{array}$ \\
\hline $\begin{array}{l}\text { Aquila } \\
\text { chrysaetos }\end{array}$ & $\begin{array}{l}\text { Urocyon littoralis } \\
\text { santacruzae }\end{array}$ & Endangered & Negative & $\begin{array}{l}\text { Predation of mature } \\
\text { animals }\end{array}$ & $\begin{array}{l}\text { US, } \\
\text { California }\end{array}$ & $\begin{array}{l}\text { Observation } \\
\text { experimenta } \\
\text { I }\end{array}$ & 73 & $\begin{array}{l}\text { Collins et al. } \\
\text { (2009) }\end{array}$ \\
\hline $\begin{array}{l}\text { Aquila } \\
\text { chrysaetos }\end{array}$ & $\begin{array}{l}\text { Urocyon littoralis } \\
\text { littoralis }\end{array}$ & Endangered & Negative & $\begin{array}{l}\text { Predation of mature } \\
\text { animals }\end{array}$ & $\begin{array}{l}\text { US, } \\
\text { California }\end{array}$ & $\begin{array}{l}\text { Observation } \\
\text { experimenta } \\
\text { I }\end{array}$ & 77 & $\begin{array}{l}\text { Coonan et al. } \\
(2005)\end{array}$ \\
\hline $\begin{array}{l}\text { Aquila } \\
\text { chrysaetos }\end{array}$ & $\begin{array}{l}\text { Urocyon littoralis } \\
\text { catalinae }\end{array}$ & Endangered & Negative & $\begin{array}{l}\text { Behaviour disruption, } \\
\text { feeding disruption }\end{array}$ & $\begin{array}{l}\text { US, } \\
\text { California }\end{array}$ & $\begin{array}{l}\text { Site } \\
\text { comparison }\end{array}$ & 67 & $\begin{array}{l}\text { Swarts et al. } \\
\text { (2009) }\end{array}$ \\
\hline $\begin{array}{l}\text { Arrhenatherum } \\
\text { elatius }\end{array}$ & $\begin{array}{l}\text { Icaricia icarioides } \\
\text { fenderi }\end{array}$ & Endangered & Negative & $\begin{array}{l}\text { Behaviour disruption, } \\
\text { breeding disruption }\end{array}$ & US, Oregon & $\mathrm{Cl}$ & 67 & Severns (2008) \\
\hline Batis maritima & $\begin{array}{l}\text { Himantopus } \\
\text { mexicanus } \\
\text { knudseni }\end{array}$ & Endangered & Negative & $\begin{array}{l}\text { Competition monopolising } \\
\text { resources, shelter/habitat }\end{array}$ & US, Hawaii & $\begin{array}{l}\text { Observation } \\
\text { experimenta } \\
\text { I }\end{array}$ & 73 & Morin (1998) \\
\hline
\end{tabular}




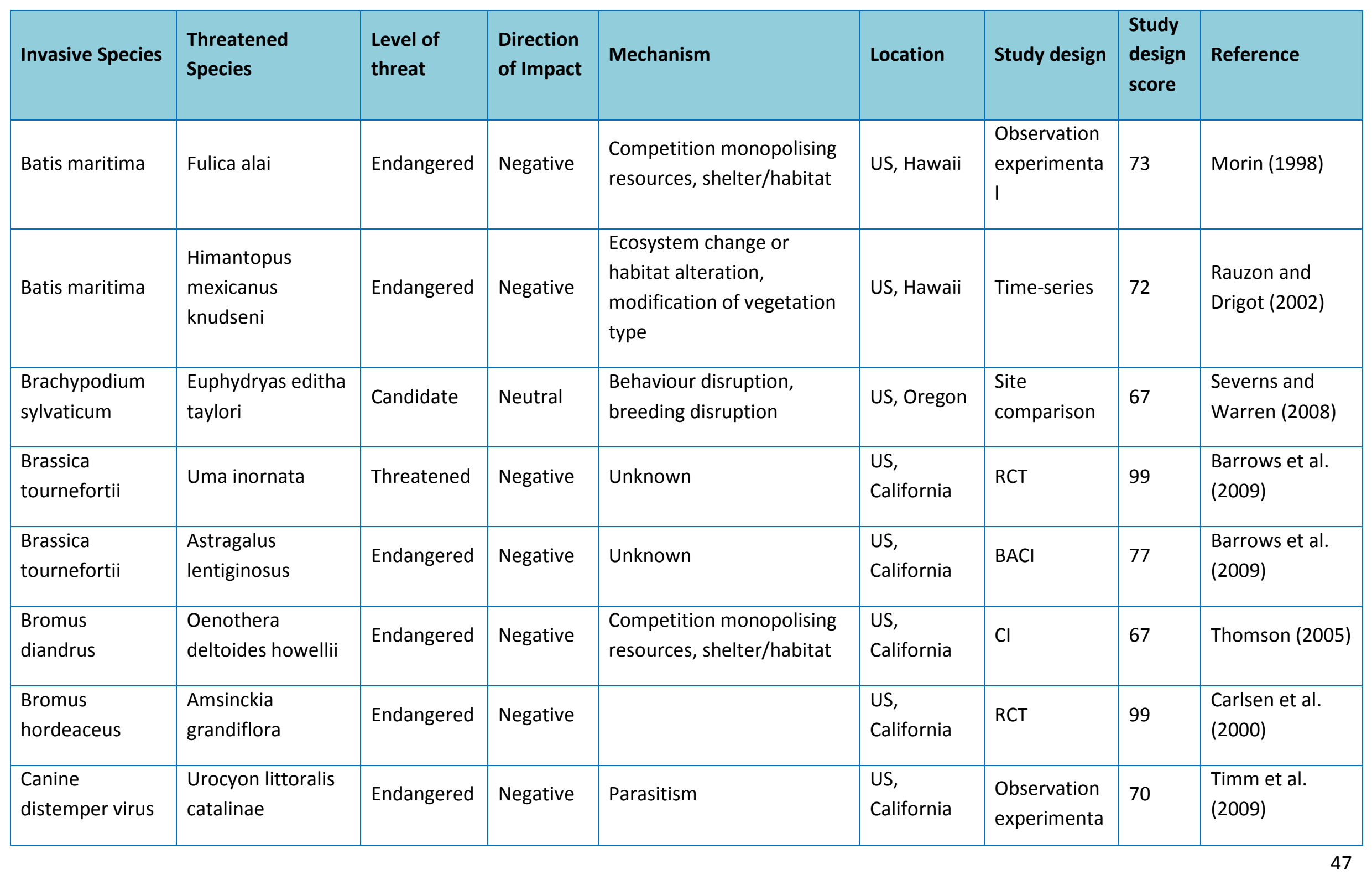




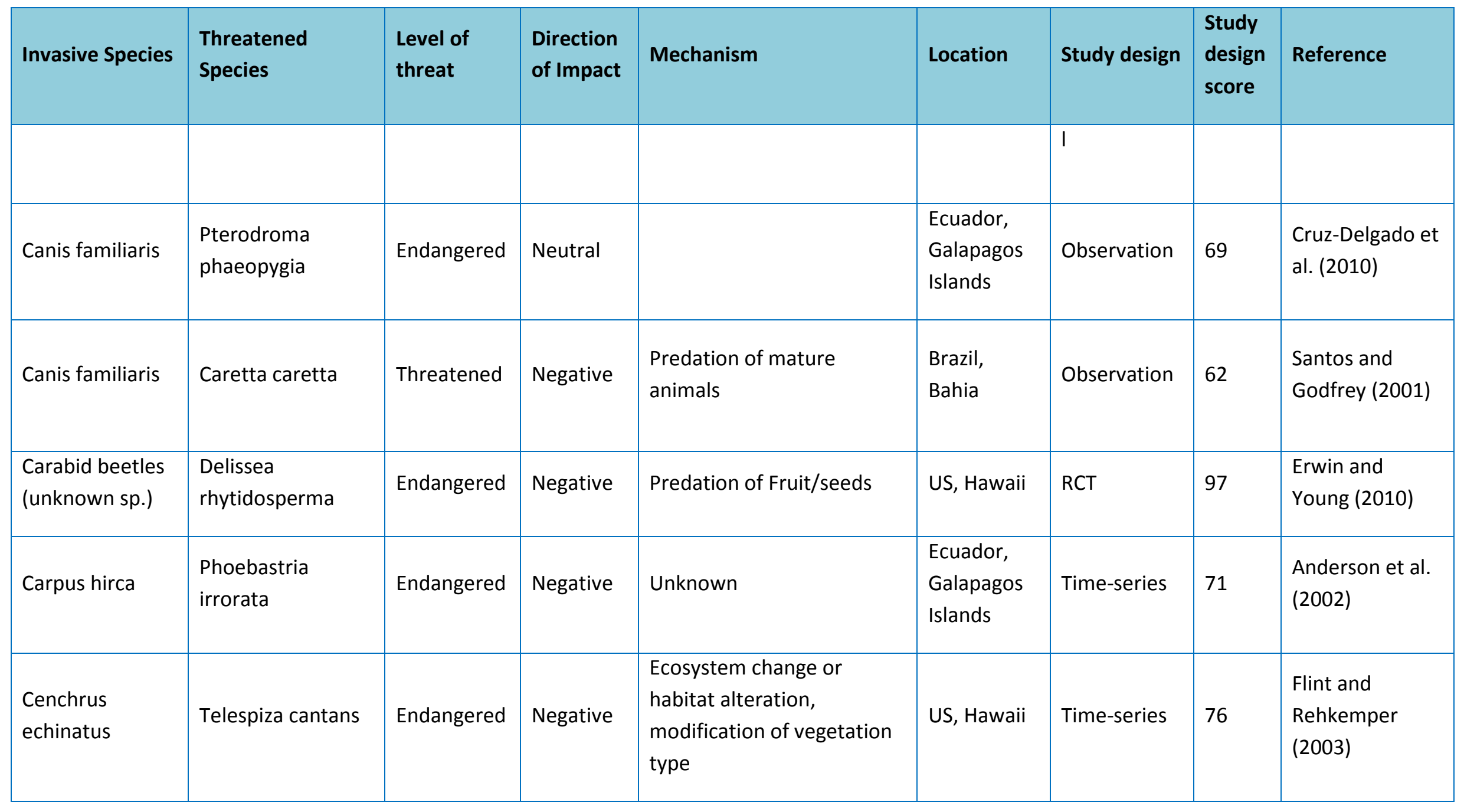




\begin{tabular}{|c|c|c|c|c|c|c|c|c|}
\hline Invasive Species & $\begin{array}{l}\text { Threatened } \\
\text { Species }\end{array}$ & $\begin{array}{l}\text { Level of } \\
\text { threat }\end{array}$ & $\begin{array}{l}\text { Direction } \\
\text { of Impact }\end{array}$ & Mechanism & Location & Study design & $\begin{array}{l}\text { Study } \\
\text { design } \\
\text { score }\end{array}$ & Reference \\
\hline $\begin{array}{l}\text { Cenchrus } \\
\text { echinatus }\end{array}$ & Anas laysanensis & Endangered & Negative & $\begin{array}{l}\text { Ecosystem change or } \\
\text { habitat alteration, } \\
\text { modification of vegetation } \\
\text { type }\end{array}$ & US, Hawaii & Time-series & 76 & $\begin{array}{l}\text { Flint and } \\
\text { Rehkemper } \\
\text { (2003) }\end{array}$ \\
\hline Cervus elaphus & Castilleja mollis & Endangered & Negative & Rooting or digging & $\begin{array}{l}\text { US, } \\
\text { California }\end{array}$ & Time-series & 77 & $\begin{array}{l}\text { McEachern et } \\
\text { al. (2009) }\end{array}$ \\
\hline Cervus elaphus & Castilleja mollis & Endangered & Negative & $\begin{array}{l}\text { Herbivory or grazing or } \\
\text { browsing }\end{array}$ & $\begin{array}{l}\text { US, } \\
\text { California }\end{array}$ & Time-series & 77 & $\begin{array}{l}\text { McEachern et } \\
\text { al. (2009) }\end{array}$ \\
\hline Cirsium arvense & $\begin{array}{l}\text { Gaura } \\
\text { neomexicana } \\
\text { coloradensis }\end{array}$ & Threatened & Neutral & & $\begin{array}{l}\text { US, } \\
\text { Wyoming }\end{array}$ & RCT & 97 & $\begin{array}{l}\text { Munk et al. } \\
(2002)\end{array}$ \\
\hline $\begin{array}{l}\text { Corbula } \\
\text { amurensis }\end{array}$ & $\begin{array}{l}\text { Hypomesus } \\
\text { transpacificus }\end{array}$ & Threatened & Neutral & & $\begin{array}{l}\text { US, } \\
\text { California }\end{array}$ & Time-series & 77 & $\begin{array}{l}\text { MacNally et al. } \\
\text { (2010) }\end{array}$ \\
\hline $\begin{array}{l}\text { Cronartium } \\
\text { ribicola }\end{array}$ & Pinus albicaulis & Candidate & Negative & $\begin{array}{l}\text { Interaction with } \\
\text { mutualisms }\end{array}$ & $\begin{array}{l}\text { US, } \\
\text { Montana }\end{array}$ & Time-series & 73 & $\begin{array}{l}\text { McKinney et al. } \\
\text { (2009) }\end{array}$ \\
\hline $\begin{array}{l}\text { Culex } \\
\text { quinquefasciatu }\end{array}$ & $\begin{array}{l}\text { Chasiempis } \\
\text { sandwichensis }\end{array}$ & Endangered & Negative & Parasitism & US, Hawaii & $\begin{array}{l}\text { Observation } \\
\text { experimenta }\end{array}$ & 77 & $\begin{array}{l}\text { Vanderwerf. } \\
\text { (2009) }\end{array}$ \\
\hline
\end{tabular}




\begin{tabular}{|c|c|c|c|c|c|c|c|c|}
\hline Invasive Species & $\begin{array}{l}\text { Threatened } \\
\text { Species }\end{array}$ & $\begin{array}{l}\text { Level of } \\
\text { threat }\end{array}$ & $\begin{array}{l}\text { Direction } \\
\text { of Impact }\end{array}$ & Mechanism & Location & Study design & $\begin{array}{l}\text { Study } \\
\text { design } \\
\text { score }\end{array}$ & Reference \\
\hline s & ibidis & & & & & I & & \\
\hline $\begin{array}{l}\text { Cyprinella } \\
\text { lutrensis }\end{array}$ & $\begin{array}{l}\text { Plagopterus } \\
\text { argentissimus }\end{array}$ & Threatened & Neutral & & US, Nevada & $\begin{array}{l}\text { Observation } \\
\text { experimenta } \\
\text { I }\end{array}$ & 77 & $\begin{array}{l}\text { Holden and } \\
\text { Golden. (2000) }\end{array}$ \\
\hline $\begin{array}{l}\text { Cyprinella } \\
\text { lutrensis }\end{array}$ & $\begin{array}{l}\text { Plagopterus } \\
\text { argentissimus }\end{array}$ & Endangered & Negative & $\begin{array}{l}\text { Competition monopolising } \\
\text { resources, food/nutrients }\end{array}$ & US, Utah & $\begin{array}{l}\text { Interrupted } \\
\text { time-series }\end{array}$ & 62 & $\begin{array}{l}\text { Holden et al. } \\
(2001)\end{array}$ \\
\hline $\begin{array}{l}\text { Deer (unknown } \\
\text { sp.) }\end{array}$ & Serianthes nelsonii & Endangered & Negative & $\begin{array}{l}\text { Herbivory/grazing/browsin } \\
\text { g of immature plants }\end{array}$ & US, Guam & Observation & 62 & $\begin{array}{l}\text { Wiles et al. } \\
(1996)\end{array}$ \\
\hline Deroceras laeve & Cyanea superba & Endangered & & & , & & & $\begin{array}{l}\text { Joe and Daehler } \\
\text { (2008) }\end{array}$ \\
\hline Deroceras laeve & $\begin{array}{l}\text { Alsinidendron } \\
\text { obovatum }\end{array}$ & Endangered & Negative & & US, Hawaii & $\mathrm{RCT}$ & 94 & $\begin{array}{l}\text { Joe and Daehler } \\
\text { (2008) }\end{array}$ \\
\hline $\begin{array}{l}\text { Diorhabda } \\
\text { elongata } \\
\text { deserticola }\end{array}$ & $\begin{array}{l}\text { Frankenia } \\
\text { johnstonii }\end{array}$ & Endangered & Neutral & $\begin{array}{l}\text { Herbivory/grazing/browsin } \\
\text { g of mature plants }\end{array}$ & $\begin{array}{l}\text { Lab } \\
\text { experiment }\end{array}$ & RCT, ex-situ & 89 & $\begin{array}{l}\text { Lewis et al. } \\
\text { (2003) }\end{array}$ \\
\hline
\end{tabular}




\begin{tabular}{|c|c|c|c|c|c|c|c|c|}
\hline Invasive Species & $\begin{array}{l}\text { Threatened } \\
\text { Species }\end{array}$ & $\begin{array}{l}\text { Level of } \\
\text { threat }\end{array}$ & $\begin{array}{l}\text { Direction } \\
\text { of Impact }\end{array}$ & Mechanism & Location & Study design & $\begin{array}{l}\text { Study } \\
\text { design } \\
\text { score }\end{array}$ & Reference \\
\hline $\begin{array}{l}\text { Dipsacus } \\
\text { sylvestris }\end{array}$ & Cirsium vinaceum & Threatened & Negative & & $\begin{array}{l}\text { US, New } \\
\text { Mexico }\end{array}$ & $\mathrm{BACl}$ & 77 & $\begin{array}{l}\text { Huenneke and } \\
\text { Thomson (1995) }\end{array}$ \\
\hline $\begin{array}{l}\text { Dipsacus } \\
\text { sylvestris }\end{array}$ & Cirsium vinaceum & Threatened & Neutral & & $\begin{array}{l}\text { US, New } \\
\text { Mexico }\end{array}$ & $\mathrm{BACl}$ & 77 & $\begin{array}{l}\text { Huenneke and } \\
\text { Thomson (1995) }\end{array}$ \\
\hline $\begin{array}{l}\text { Dreissena } \\
\text { bugensis }\end{array}$ & $\begin{array}{l}\text { Oncorhynchus } \\
\text { tshawytscha }\end{array}$ & Threatened & Negative & Altered food web & $\begin{array}{l}\text { US, } \\
\text { Michigan }\end{array}$ & $\begin{array}{l}\text { Interrupted } \\
\text { time-series }\end{array}$ & 63 & $\begin{array}{l}\text { Madenjian et al. } \\
(2006)\end{array}$ \\
\hline $\begin{array}{l}\text { Dreissena } \\
\text { bugensis }\end{array}$ & $\begin{array}{l}\text { Epioblasma } \\
\text { triquetra }\end{array}$ & Endangered & Neutral & $\begin{array}{l}\text { Competition monopolising } \\
\text { resources, food/nutrients }\end{array}$ & $\begin{array}{l}\text { US, } \\
\text { Michigan }\end{array}$ & $\begin{array}{l}\text { Interrupted } \\
\text { time-series }\end{array}$ & 58 & $\begin{array}{l}\text { Schloesser et al. } \\
\text { (1998) }\end{array}$ \\
\hline $\begin{array}{l}\text { Dreissena } \\
\text { bugensis }\end{array}$ & Villosa fabalis & Endangered & Neutral & $\begin{array}{l}\text { Competition monopolising } \\
\text { resources, food/nutrients }\end{array}$ & $\begin{array}{l}\text { US, } \\
\text { Michigan }\end{array}$ & $\begin{array}{l}\text { Interrupted } \\
\text { time-series }\end{array}$ & & $\begin{array}{l}\text { Schloesseret al. } \\
\text { (1998) }\end{array}$ \\
\hline $\begin{array}{l}\text { Dreissena } \\
\text { polymorpha }\end{array}$ & $\begin{array}{l}\text { Oncorhynchus } \\
\text { tshawytscha }\end{array}$ & Threatened & Negative & Altered food web & $\begin{array}{l}\text { US, } \\
\text { Michigan }\end{array}$ & $\begin{array}{l}\text { Interrupted } \\
\text { time-series }\end{array}$ & 63 & $\begin{array}{l}\text { Madenjian et al. } \\
\text { (2006) }\end{array}$ \\
\hline $\begin{array}{l}\text { Dreissena } \\
\text { polymorpha }\end{array}$ & $\begin{array}{l}\text { Epioblasma } \\
\text { torulosa rangiana }\end{array}$ & Endangered & Negative & $\begin{array}{l}\text { Competition monopolising } \\
\text { resources, food/nutrients }\end{array}$ & $\begin{array}{l}\text { US, } \\
\text { Michigan }\end{array}$ & $\begin{array}{l}\text { Interrupted } \\
\text { time-series }\end{array}$ & 58 & $\begin{array}{l}\text { Schloesser et al. } \\
\text { (1998) }\end{array}$ \\
\hline
\end{tabular}




\begin{tabular}{|c|c|c|c|c|c|c|c|c|}
\hline Invasive Species & $\begin{array}{l}\text { Threatened } \\
\text { Species }\end{array}$ & $\begin{array}{l}\text { Level of } \\
\text { threat }\end{array}$ & $\begin{array}{l}\text { Direction } \\
\text { of Impact }\end{array}$ & Mechanism & Location & Study design & $\begin{array}{l}\text { Study } \\
\text { design } \\
\text { score }\end{array}$ & Reference \\
\hline $\begin{array}{l}\text { Dreissena } \\
\text { polymorpha }\end{array}$ & $\begin{array}{l}\text { Epioblasma } \\
\text { torulosa rangiana }\end{array}$ & Endangered & Negative & $\begin{array}{l}\text { Competition monopolising } \\
\text { resources, food/nutrients }\end{array}$ & $\begin{array}{l}\text { US, } \\
\text { Michigan }\end{array}$ & $\begin{array}{l}\text { Interrupted } \\
\text { time-series }\end{array}$ & 58 & $\begin{array}{l}\text { Schloesser et al. } \\
\text { (1998) }\end{array}$ \\
\hline Felis catus & Amazona vittata & Endangered & Negative & Predation & $\begin{array}{l}\text { Puerto } \\
\text { Rico, Sierra } \\
\text { de Luquillo } \\
\text { Mountains }\end{array}$ & Observation & 55 & $\begin{array}{l}\text { Engeman et al. } \\
(2006)\end{array}$ \\
\hline Felis catus & $\begin{array}{l}\text { Pterodroma } \\
\text { phaeopygia } \\
\text { sandwichensis }\end{array}$ & Endangered & Negative & Unknown & $\begin{array}{l}\text { Ecuador, } \\
\text { Galapagos } \\
\text { Islands }\end{array}$ & Observation & 55 & $\begin{array}{l}\text { Cruz and Cruz } \\
(1987)\end{array}$ \\
\hline Felis catus & $\begin{array}{l}\text { Pterodroma } \\
\text { phaeopygia }\end{array}$ & Endangered & Neutral & & $\begin{array}{l}\text { Ecuador, } \\
\text { Galapagos } \\
\text { Islands }\end{array}$ & Observation & 69 & $\begin{array}{l}\text { Cruz-Delgado et } \\
\text { al. (2010) }\end{array}$ \\
\hline
\end{tabular}




\begin{tabular}{|c|c|c|c|c|c|c|c|c|}
\hline Invasive Species & $\begin{array}{l}\text { Threatened } \\
\text { Species }\end{array}$ & $\begin{array}{l}\text { Level of } \\
\text { threat }\end{array}$ & $\begin{array}{l}\text { Direction } \\
\text { of Impact }\end{array}$ & Mechanism & Location & Study design & $\begin{array}{l}\text { Study } \\
\text { design } \\
\text { score }\end{array}$ & Reference \\
\hline Felis catus & $\begin{array}{l}\text { Oryzomys palustris } \\
\text { natator }\end{array}$ & Endangered & Negative & & $\begin{array}{l}\text { Ecuador, } \\
\text { Galapagos } \\
\text { Islands }\end{array}$ & $\begin{array}{l}\text { Site } \\
\text { comparison }\end{array}$ & 67 & $\begin{array}{l}\text { Dexter et al. } \\
(2004)\end{array}$ \\
\hline Felis catus & $\begin{array}{l}\text { Chasiempis } \\
\text { sandwichensis } \\
\text { ibidis }\end{array}$ & Endangered & Negative & $\begin{array}{l}\text { Predation of mature } \\
\text { animals }\end{array}$ & US, Hawaii & $\begin{array}{l}\text { Observation } \\
\text { experimenta } \\
\text { I }\end{array}$ & 77 & $\begin{array}{l}\text { Hess et al. } \\
(2004)\end{array}$ \\
\hline Felis catus & $\begin{array}{l}\text { Pterodroma } \\
\text { phaeopygia } \\
\text { sandwichensis }\end{array}$ & Endangered & Negative & $\begin{array}{l}\text { Predation of mature } \\
\text { animals }\end{array}$ & US, Hawaii & $\begin{array}{l}\text { Observation } \\
\text { experimenta } \\
\text { I }\end{array}$ & 75 & $\begin{array}{l}\text { Hess et al. } \\
(2008)\end{array}$ \\
\hline Felis catus & $\begin{array}{l}\text { Himantopus } \\
\text { mexicanus } \\
\text { knudseni }\end{array}$ & Endangered & Negative & & US, Hawaii & $\begin{array}{l}\text { Observation } \\
\text { experimenta } \\
\text { I }\end{array}$ & 73 & Morin (1998) \\
\hline Felis catus & Fulica alai & Endangered & Negative & & US, Hawaii & $\begin{array}{l}\text { Observation } \\
\text { experimenta } \\
\text { I }\end{array}$ & 73 & Morin (1998) \\
\hline Felis catus & $\begin{array}{l}\text { Lanius } \\
\text { ludovicianus } \\
\text { mearnsi }\end{array}$ & Endangered & Negative & Predation of juveniles & $\begin{array}{l}\text { US, } \\
\text { California }\end{array}$ & Observation & 60 & $\begin{array}{l}\text { Scott and } \\
\text { Morrison (1990) }\end{array}$ \\
\hline
\end{tabular}




\begin{tabular}{|c|c|c|c|c|c|c|c|c|}
\hline Invasive Species & $\begin{array}{l}\text { Threatened } \\
\text { Species }\end{array}$ & $\begin{array}{l}\text { Level of } \\
\text { threat }\end{array}$ & $\begin{array}{l}\text { Direction } \\
\text { of Impact }\end{array}$ & Mechanism & Location & Study design & $\begin{array}{l}\text { Study } \\
\text { design } \\
\text { score }\end{array}$ & Reference \\
\hline Gambusia affinis & $\begin{array}{l}\text { lotichthys } \\
\text { phlegethontis }\end{array}$ & Candidate & Negative & $\begin{array}{l}\text { Competition monopolising } \\
\text { resources, shelter/habitat }\end{array}$ & US, Utah & $\begin{array}{l}\text { Interrupted } \\
\text { time-series }\end{array}$ & 61 & $\begin{array}{l}\text { Ayala et al. } \\
\text { (2007) }\end{array}$ \\
\hline Gambusia affinis & $\begin{array}{l}\text { Poeciliopsis } \\
\text { occidentalis }\end{array}$ & Endangered & Negative & Predation & US, Arizona & $\begin{array}{l}\text { Site } \\
\text { comparison }\end{array}$ & 67 & $\begin{array}{l}\text { Meffe et al. } \\
\text { (1983) }\end{array}$ \\
\hline Gambusia affinis & $\begin{array}{l}\text { lotichthys } \\
\text { phlegethontis }\end{array}$ & Candidate & Negative & Predation & US, Utah & RCT & 99 & $\begin{array}{l}\text { Mills et al. } \\
(2004)\end{array}$ \\
\hline Gambusia affinis & $\begin{array}{l}\text { lotichthys } \\
\text { phlegethontis }\end{array}$ & Candidate & Negative & Predation & $\begin{array}{l}\text { Lab } \\
\text { experiment }\end{array}$ & RCT & 97 & $\begin{array}{l}\text { Mills et al. } \\
\text { (2004) }\end{array}$ \\
\hline
\end{tabular}




\begin{tabular}{|c|c|c|c|c|c|c|c|c|}
\hline Invasive Species & $\begin{array}{l}\text { Threatened } \\
\text { Species }\end{array}$ & $\begin{array}{l}\text { Level of } \\
\text { threat }\end{array}$ & $\begin{array}{l}\text { Direction } \\
\text { of Impact }\end{array}$ & Mechanism & Location & Study design & $\begin{array}{l}\text { Study } \\
\text { design } \\
\text { score }\end{array}$ & Reference \\
\hline $\begin{array}{l}\text { Gypsophila } \\
\text { paniculata }\end{array}$ & Cirsium pitcheri & Threatened & Negative & $\begin{array}{l}\text { Competition monopolising } \\
\text { resources }\end{array}$ & $\begin{array}{l}\text { US, } \\
\text { Michigan }\end{array}$ & RCT & 97 & $\begin{array}{l}\text { Baskett et al. } \\
\text { (2011) }\end{array}$ \\
\hline $\begin{array}{l}\text { Herpestes } \\
\text { auropunctatus }\end{array}$ & $\begin{array}{l}\text { Himantopus } \\
\text { mexicanus } \\
\text { knudseni }\end{array}$ & Endangered & Negative & & US, Hawaii & $\begin{array}{l}\text { Observation } \\
\text { experimenta } \\
\text { I }\end{array}$ & 73 & Morin (1998) \\
\hline $\begin{array}{l}\text { Herpestes } \\
\text { auropunctatus }\end{array}$ & Fulica alai & Endangered & Negative & & US, Hawaii & $\begin{array}{l}\text { Observation } \\
\text { experimenta } \\
\text { I }\end{array}$ & 73 & Morin (1998) \\
\hline $\begin{array}{l}\text { Herpestes } \\
\text { javanicus }\end{array}$ & Amazona vittata & Endangered & Negative & Predation & $\begin{array}{l}\text { Puerto } \\
\text { Rico, Sierra } \\
\text { de Luquillo } \\
\text { Mountains }\end{array}$ & Observation & 55 & $\begin{array}{l}\text { Engeman et al. } \\
(2006)\end{array}$ \\
\hline
\end{tabular}




\begin{tabular}{|c|c|c|c|c|c|c|c|c|}
\hline Invasive Species & $\begin{array}{l}\text { Threatened } \\
\text { Species }\end{array}$ & $\begin{array}{l}\text { Level of } \\
\text { threat }\end{array}$ & $\begin{array}{l}\text { Direction } \\
\text { of Impact }\end{array}$ & Mechanism & Location & Study design & $\begin{array}{l}\text { Study } \\
\text { design } \\
\text { score }\end{array}$ & Reference \\
\hline $\begin{array}{l}\text { Ictalurus } \\
\text { punctatus }\end{array}$ & Gila cypha & Endangered & Negative & Predation & US, Arizona & $\begin{array}{l}\text { Observation } \\
\text { experimenta } \\
\text { I }\end{array}$ & 77 & $\begin{array}{l}\text { Marsh and } \\
\text { Douglas (1997) }\end{array}$ \\
\hline $\begin{array}{l}\text { Juniperus } \\
\text { virginiana }\end{array}$ & $\begin{array}{l}\text { Nicrophorus } \\
\text { americanus }\end{array}$ & Endangered & Negative & $\begin{array}{l}\text { Behaviour disruption, } \\
\text { feeding disruption }\end{array}$ & $\begin{array}{l}\text { US, } \\
\text { Nebraska }\end{array}$ & $\begin{array}{l}\text { Site } \\
\text { comparison }\end{array}$ & 67 & $\begin{array}{l}\text { Walker and } \\
\text { Hoback (2007) }\end{array}$ \\
\hline $\begin{array}{l}\text { Lepomis } \\
\text { cyanellus }\end{array}$ & $\begin{array}{l}\text { Ambystoma } \\
\text { tigrinum stebbinsi }\end{array}$ & Endangered & Negative & & US, Arizona & $\begin{array}{l}\text { Interrupted } \\
\text { time-series }\end{array}$ & 61 & $\begin{array}{l}\text { Maret, et al. } \\
(2006)\end{array}$ \\
\hline
\end{tabular}




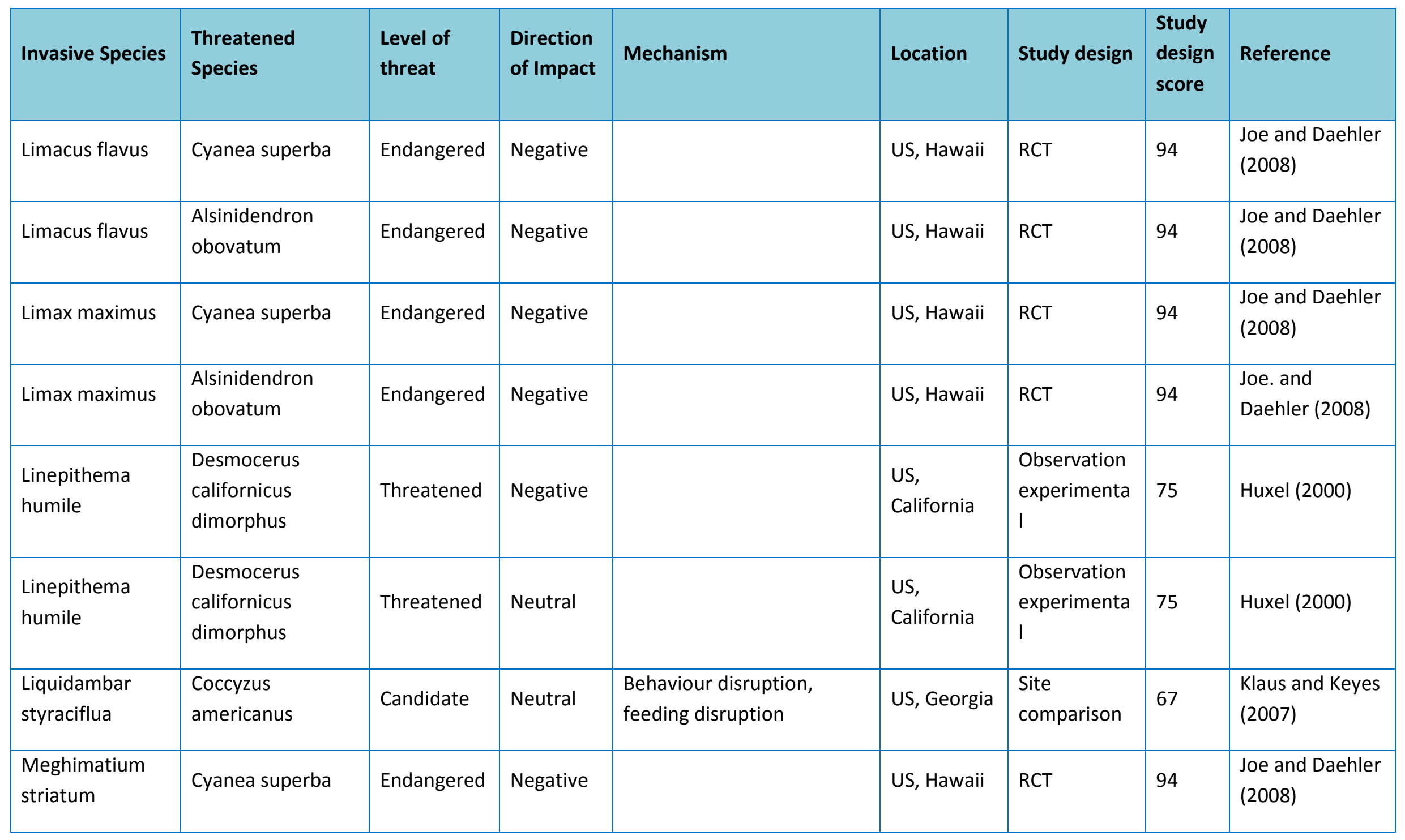




\begin{tabular}{|c|c|c|c|c|c|c|c|c|}
\hline Invasive Species & $\begin{array}{l}\text { Threatened } \\
\text { Species }\end{array}$ & $\begin{array}{l}\text { Level of } \\
\text { threat }\end{array}$ & $\begin{array}{l}\text { Direction } \\
\text { of Impact }\end{array}$ & Mechanism & Location & Study design & $\begin{array}{l}\text { Study } \\
\text { design } \\
\text { score }\end{array}$ & Reference \\
\hline $\begin{array}{l}\text { Micropterus } \\
\text { salmoides }\end{array}$ & $\begin{array}{l}\text { Ambystoma } \\
\text { tigrinum stebbinsi }\end{array}$ & Endangered & Negative & & US, Arizona & $\begin{array}{l}\text { Interrupted } \\
\text { time-series }\end{array}$ & 61 & $\begin{array}{l}\text { Maret et al. } \\
(2006)\end{array}$ \\
\hline $\begin{array}{l}\text { Microstegium } \\
\text { vimineum }\end{array}$ & $\begin{array}{l}\text { Coccyzus } \\
\text { americanus }\end{array}$ & Candidate & Negative & Unknown & $\begin{array}{l}\text { US, New } \\
\text { Jersey }\end{array}$ & $\begin{array}{l}\text { Interrupted } \\
\text { time-series }\end{array}$ & 60 & $\begin{array}{l}\text { Baiser et al. } \\
(2008)\end{array}$ \\
\hline $\begin{array}{l}\text { Molothrus } \\
\text { bonariensis }\end{array}$ & $\begin{array}{l}\text { Agelaius } \\
\text { xanthomus }\end{array}$ & Endangered & Negative & Parasitism & $\begin{array}{l}\text { US, Puerto } \\
\text { Rico }\end{array}$ & $\begin{array}{l}\text { Observation } \\
\text { experimenta } \\
\text { I }\end{array}$ & 77 & $\begin{array}{l}\text { Wiley et al. } \\
\text { (1991) }\end{array}$ \\
\hline $\begin{array}{l}\text { Neogobius } \\
\text { melanostomus }\end{array}$ & Cottus bairdii & Threatened & Neutral & $\begin{array}{l}\text { Competition monopolising } \\
\text { resources, food/nutrients }\end{array}$ & $\begin{array}{l}\text { US, } \\
\text { Michigan }\end{array}$ & $\begin{array}{l}\text { Site } \\
\text { comparison }\end{array}$ & 67 & $\begin{array}{l}\text { Kornis et al. } \\
(2012)\end{array}$ \\
\hline $\begin{array}{l}\text { Neogobius } \\
\text { melanostomus }\end{array}$ & $\begin{array}{l}\text { Oncorhynchus } \\
\text { mykiss }\end{array}$ & Threatened & Neutral & $\begin{array}{l}\text { Competition monopolising } \\
\text { resources, food/nutrients }\end{array}$ & $\begin{array}{l}\text { US, } \\
\text { Michigan }\end{array}$ & $\begin{array}{l}\text { Site } \\
\text { comparison }\end{array}$ & 67 & $\begin{array}{l}\text { Kornis et al. } \\
\text { (2012) }\end{array}$ \\
\hline
\end{tabular}




\begin{tabular}{|c|c|c|c|c|c|c|c|c|}
\hline Invasive Species & $\begin{array}{l}\text { Threatened } \\
\text { Species }\end{array}$ & $\begin{array}{l}\text { Level of } \\
\text { threat }\end{array}$ & $\begin{array}{l}\text { Direction } \\
\text { of Impact }\end{array}$ & Mechanism & Location & Study design & $\begin{array}{l}\text { Study } \\
\text { design } \\
\text { score }\end{array}$ & Reference \\
\hline $\begin{array}{l}\text { Odocoileus } \\
\text { hemionus }\end{array}$ & Castilleja mollis & Endangered & Negative & $\begin{array}{l}\text { Herbivory or grazing or } \\
\text { browsing }\end{array}$ & $\begin{array}{l}\text { US, } \\
\text { California }\end{array}$ & Time-series & 77 & $\begin{array}{l}\text { McEachern et } \\
\text { al. (2009) }\end{array}$ \\
\hline $\begin{array}{l}\text { Oncorhynchus } \\
\text { mykiss }\end{array}$ & Salmo salar & Endangered & Negative & Behaviour disruption & $\begin{array}{l}\text { Lab } \\
\text { experiment }\end{array}$ & $\mathrm{BACl}$ & 79 & $\begin{array}{l}\text { Blanchet et al. } \\
\text { (2007) }\end{array}$ \\
\hline $\begin{array}{l}\text { Oncorhynchus } \\
\text { mykiss }\end{array}$ & Salmo salar & Endangered & Negative & Behaviour disruption & $\begin{array}{l}\text { Canada, } \\
\text { Quebec }\end{array}$ & $\mathrm{BACl}$ & 79 & $\begin{array}{l}\text { Blanchet et al. } \\
\text { (2007) }\end{array}$ \\
\hline $\begin{array}{l}\text { Oncorhynchus } \\
\text { mykiss }\end{array}$ & Salmo salar & Endangered & Negative & $\begin{array}{l}\text { Behaviour disruption, } \\
\text { feeding disruption }\end{array}$ & $\begin{array}{l}\text { Lab } \\
\text { experiment }\end{array}$ & RCT, ex-situ & 89 & $\begin{array}{l}\text { Van Zwol et al. } \\
(2012)\end{array}$ \\
\hline $\begin{array}{l}\text { Oplismenus } \\
\text { hirtellus }\end{array}$ & $\begin{array}{l}\text { Delissea } \\
\text { rhytidosperma }\end{array}$ & Endangered & Negative & Predation of Fruit/seeds & US, Hawaii & RCT & 97 & $\begin{array}{l}\text { Erwin, and } \\
\text { Young (2010) }\end{array}$ \\
\hline
\end{tabular}




\begin{tabular}{|c|c|c|c|c|c|c|c|c|}
\hline Invasive Species & $\begin{array}{l}\text { Threatened } \\
\text { Species }\end{array}$ & $\begin{array}{l}\text { Level of } \\
\text { threat }\end{array}$ & $\begin{array}{l}\text { Direction } \\
\text { of Impact }\end{array}$ & Mechanism & Location & Study design & $\begin{array}{l}\text { Study } \\
\text { design } \\
\text { score }\end{array}$ & Reference \\
\hline Ovis aries & $\begin{array}{l}\text { Helianthemum } \\
\text { greenei }\end{array}$ & Endangered & Negative & $\begin{array}{l}\text { Herbivory/grazing/browsin } \\
\mathrm{g} \text { of mature plants }\end{array}$ & $\begin{array}{l}\text { US, } \\
\text { California }\end{array}$ & $\begin{array}{l}\text { Interrupted } \\
\text { time-series }\end{array}$ & 67 & $\begin{array}{l}\text { Klinger et al. } \\
(2003)\end{array}$ \\
\hline Ovis aries & $\begin{array}{l}\text { Malacothrix } \\
\text { squalida }\end{array}$ & Endangered & Neutral & $\begin{array}{l}\text { Herbivory/grazing/browsin } \\
\mathrm{g} \text { of mature plants }\end{array}$ & $\begin{array}{l}\text { US, } \\
\text { California }\end{array}$ & $\begin{array}{l}\text { Interrupted } \\
\text { time-series }\end{array}$ & 67 & $\begin{array}{l}\text { Klinger et al. } \\
\text { (2003) }\end{array}$ \\
\hline Ovis aries & $\begin{array}{l}\text { Thysanocarpus } \\
\text { conchuliferus }\end{array}$ & Endangered & Positive & $\begin{array}{l}\text { Herbivory/grazing/browsin } \\
\mathrm{g} \text { of mature plants }\end{array}$ & $\begin{array}{l}\text { US, } \\
\text { California }\end{array}$ & $\begin{array}{l}\text { Interrupted } \\
\text { time-series }\end{array}$ & 67 & $\begin{array}{l}\text { Klinger et al. } \\
\text { (2003) }\end{array}$ \\
\hline
\end{tabular}




\begin{tabular}{|c|c|c|c|c|c|c|c|c|}
\hline Invasive Species & $\begin{array}{l}\text { Threatened } \\
\text { Species }\end{array}$ & $\begin{array}{l}\text { Level of } \\
\text { threat }\end{array}$ & $\begin{array}{l}\text { Direction } \\
\text { of Impact }\end{array}$ & Mechanism & Location & Study design & $\begin{array}{l}\text { Study } \\
\text { design } \\
\text { score }\end{array}$ & Reference \\
\hline Ovis aries & Dudleya nesiotica & Endangered & Positive & $\begin{array}{l}\text { Herbivory/grazing/browsin } \\
\mathrm{g} \text { of mature plants }\end{array}$ & $\begin{array}{l}\text { US, } \\
\text { California }\end{array}$ & $\begin{array}{l}\text { Interrupted } \\
\text { time-series }\end{array}$ & 67 & $\begin{array}{l}\text { Klinger et al. } \\
(2003)\end{array}$ \\
\hline $\begin{array}{l}\text { Owl (unknown } \\
\text { sp.) }\end{array}$ & $\begin{array}{l}\text { Pterodroma } \\
\text { phaeopygia }\end{array}$ & Endangered & Neutral & & $\begin{array}{l}\text { Ecuador, } \\
\text { Galapagos } \\
\text { Islands }\end{array}$ & Observation & 69 & $\begin{array}{l}\text { Cruz-Delgado et } \\
\text { al. (2010) }\end{array}$ \\
\hline $\begin{array}{l}\text { Parapholis } \\
\text { incurva }\end{array}$ & $\begin{array}{l}\text { Cordylanthus } \\
\text { maritimus } \\
\text { maritimus }\end{array}$ & Endangered & Negative & Parasitism & $\begin{array}{l}\text { US, } \\
\text { California }\end{array}$ & RCT, ex-situ & 89 & $\begin{array}{l}\text { Fellows. and } \\
\text { Zedler (2005) }\end{array}$ \\
\hline $\begin{array}{l}\text { Pennisetum } \\
\text { setaceum }\end{array}$ & Kokia drynarioides & Endangered & Negative & & US, Hawaii & RCT, ex-situ & 89 & $\begin{array}{l}\text { Cabin et al. } \\
\text { (2002) }\end{array}$ \\
\hline
\end{tabular}




\begin{tabular}{|c|c|c|c|c|c|c|c|c|}
\hline Invasive Species & $\begin{array}{l}\text { Threatened } \\
\text { Species }\end{array}$ & $\begin{array}{l}\text { Level of } \\
\text { threat }\end{array}$ & $\begin{array}{l}\text { Direction } \\
\text { of Impact }\end{array}$ & Mechanism & Location & Study design & $\begin{array}{l}\text { Study } \\
\text { design } \\
\text { score }\end{array}$ & Reference \\
\hline $\begin{array}{l}\text { Pennisetum } \\
\text { setaceum }\end{array}$ & $\begin{array}{l}\text { Colubrina } \\
\text { oppositifolia }\end{array}$ & Endangered & Neutral & & US, Hawaii & RCT & 99 & $\begin{array}{l}\text { Cabin et al. } \\
(2002)\end{array}$ \\
\hline $\begin{array}{l}\text { Pomacea } \\
\text { insularum }\end{array}$ & $\begin{array}{l}\text { Rostrhamus } \\
\text { sociabilis } \\
\text { plumbeus }\end{array}$ & Endangered & Negative & $\begin{array}{l}\text { Behaviour disruption, } \\
\text { feeding disruption }\end{array}$ & US, Florida & Observation & 65 & $\begin{array}{l}\text { Cattau et al. } \\
\text { (2010) }\end{array}$ \\
\hline $\begin{array}{l}\text { Potamopyrgus } \\
\text { antipodarum }\end{array}$ & $\begin{array}{l}\text { Eucyclogobius } \\
\text { newberryi }\end{array}$ & Endangered & Positive & & $\begin{array}{l}\text { US, } \\
\text { California }\end{array}$ & $\begin{array}{l}\text { Observation } \\
\text { experimenta } \\
\text { I }\end{array}$ & 75 & $\begin{array}{l}\text { Hellmair et al. } \\
\text { (2011) }\end{array}$ \\
\hline $\begin{array}{l}\text { Pylodictis } \\
\text { olivaris }\end{array}$ & $\begin{array}{l}\text { Notropis } \\
\text { mekistocholas }\end{array}$ & Endangered & Neutral & & $\begin{array}{l}\text { US, North } \\
\text { Carolina }\end{array}$ & $\begin{array}{l}\text { Observation } \\
\text { experimenta } \\
\text { I }\end{array}$ & 77 & $\begin{array}{l}\text { Baumann and } \\
\text { Kwak (2011) }\end{array}$ \\
\hline
\end{tabular}




\begin{tabular}{|c|c|c|c|c|c|c|c|c|}
\hline Invasive Species & $\begin{array}{l}\text { Threatened } \\
\text { Species }\end{array}$ & $\begin{array}{l}\text { Level of } \\
\text { threat }\end{array}$ & $\begin{array}{l}\text { Direction } \\
\text { of Impact }\end{array}$ & Mechanism & Location & Study design & $\begin{array}{l}\text { Study } \\
\text { design } \\
\text { score }\end{array}$ & Reference \\
\hline $\begin{array}{l}\text { Pylodictis } \\
\text { olivaris }\end{array}$ & $\begin{array}{l}\text { Moxostoma } \\
\text { (unknown sp.) }\end{array}$ & Candidate & Neutral & & $\begin{array}{l}\text { US, North } \\
\text { Carolina }\end{array}$ & $\begin{array}{l}\text { Observation } \\
\text { experimenta } \\
\text { I }\end{array}$ & 77 & $\begin{array}{l}\text { Baumann and } \\
\text { Kwak (2011) }\end{array}$ \\
\hline $\begin{array}{l}\text { Python molurus } \\
\text { bivittatus }\end{array}$ & $\begin{array}{l}\text { Mycteria } \\
\text { americana }\end{array}$ & Endangered & Negative & Predation & US, Florida & $\begin{array}{l}\text { Observation } \\
\text { experimenta } \\
\text { I }\end{array}$ & 75 & $\begin{array}{l}\text { Dove et al. } \\
\text { (2011) }\end{array}$ \\
\hline Quercus nigra & $\begin{array}{l}\text { Coccyzus } \\
\text { americanus }\end{array}$ & Candidate & Neutral & $\begin{array}{l}\text { Behaviour disruption, } \\
\text { feeding disruption }\end{array}$ & US, Georgia & $\begin{array}{l}\text { Site } \\
\text { comparison }\end{array}$ & 67 & $\begin{array}{l}\text { Klaus and Keyes } \\
\text { (2007) }\end{array}$ \\
\hline $\begin{array}{l}\text { Rana } \\
\text { catesbeiana }\end{array}$ & Rana draytonii & Threatened & Negative & $\begin{array}{l}\text { Competition monopolising } \\
\text { resources, shelter/habitat }\end{array}$ & $\begin{array}{l}\text { US, } \\
\text { California }\end{array}$ & $\mathrm{BACl}$ & 75 & $\begin{array}{l}\text { D'Amore et al. } \\
\text { (2009) }\end{array}$ \\
\hline $\begin{array}{l}\text { Rana } \\
\text { catesbeiana }\end{array}$ & Rana draytonii & Threatened & Negative & $\begin{array}{l}\text { Behaviour disruption, } \\
\text { breeding disruption }\end{array}$ & $\begin{array}{l}\text { US, } \\
\text { California }\end{array}$ & Observation & 62 & $\begin{array}{l}\text { D'Amore et al. } \\
\text { (2009) }\end{array}$ \\
\hline $\begin{array}{l}\text { Rana } \\
\text { catesbeiana }\end{array}$ & Rana draytonii & Threatened & Negative & $\begin{array}{l}\text { Predation of mature } \\
\text { animals }\end{array}$ & $\begin{array}{l}\text { US, } \\
\text { California }\end{array}$ & Observation & 62 & $\begin{array}{l}\text { D'Amore et al. } \\
\text { (2009) }\end{array}$ \\
\hline $\begin{array}{l}\text { Rana } \\
\text { catesbeiana }\end{array}$ & $\begin{array}{l}\text { Ambystoma } \\
\text { tigrinum stebbinsi }\end{array}$ & Endangered & Negative & & US, Arizona & $\begin{array}{l}\text { Interrupted } \\
\text { time-series }\end{array}$ & 61 & $\begin{array}{l}\text { Maret et al. } \\
(2006)\end{array}$ \\
\hline Rana & Ambystoma & Endangered & Negative & Predation of juveniles & $\begin{array}{l}\text { Lab } \\
\text { experiment }\end{array}$ & $\begin{array}{l}\text { Observation } \\
\text { experimenta }\end{array}$ & 75 & Maret et al. \\
\hline
\end{tabular}




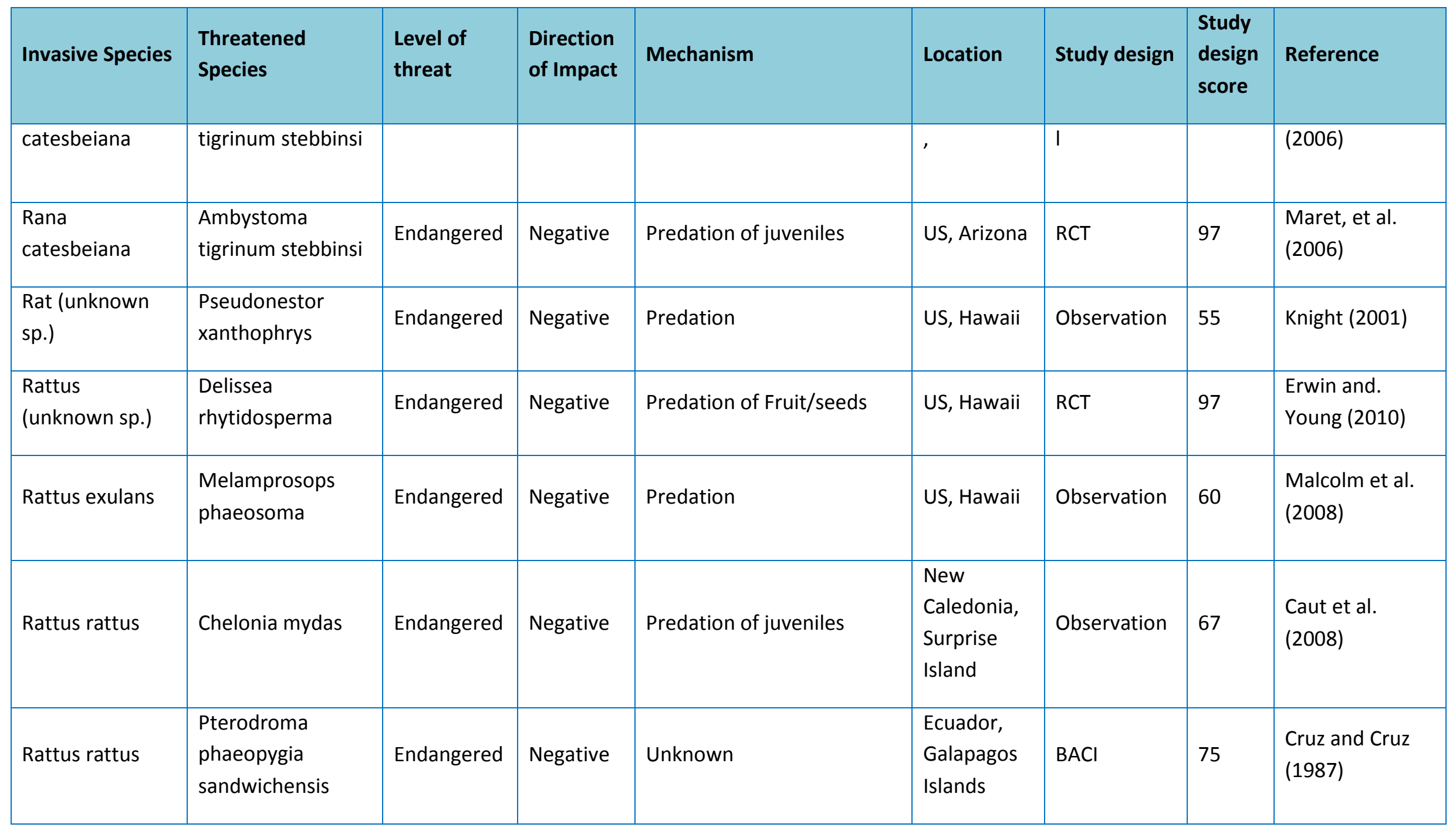




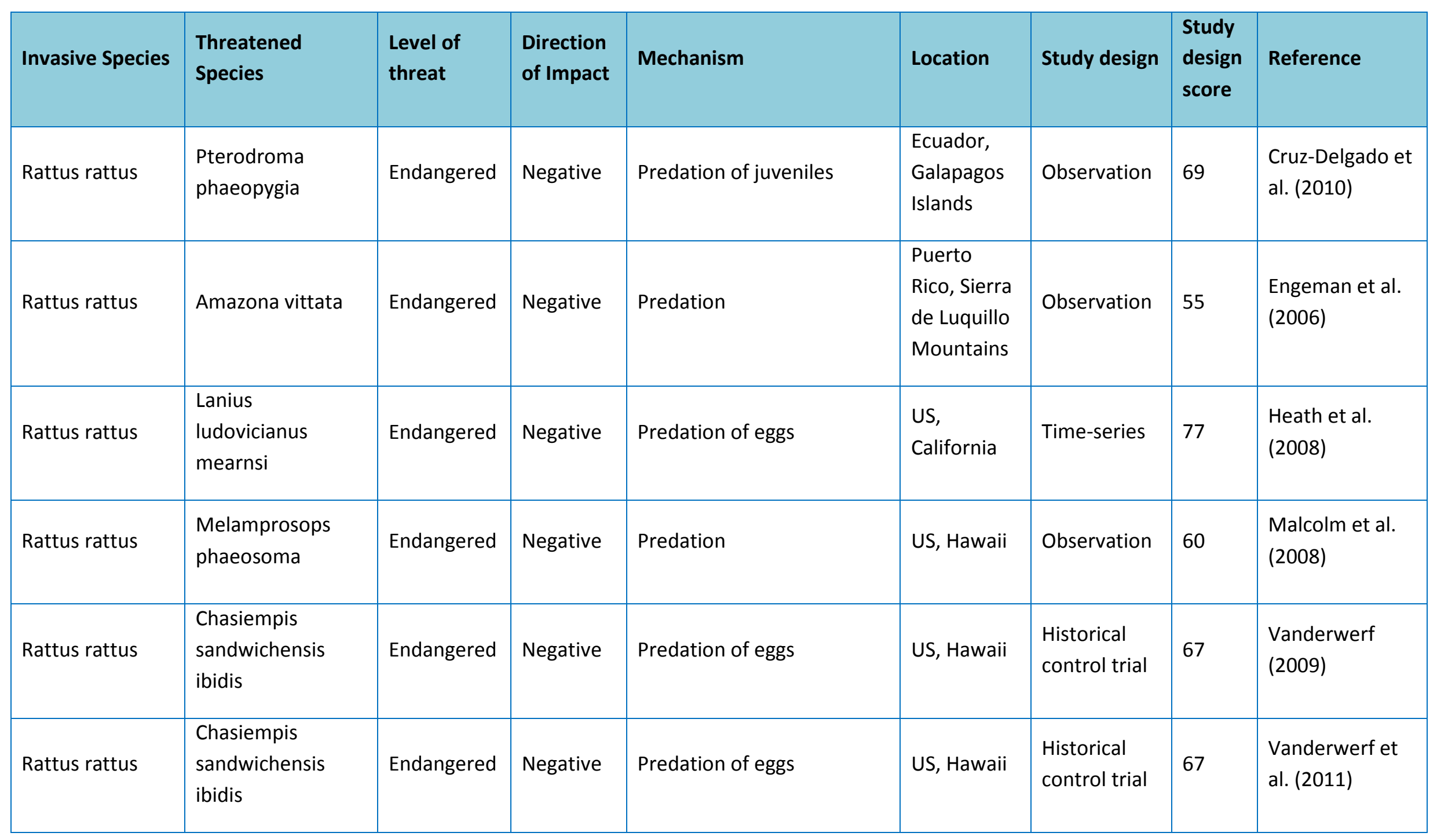




\begin{tabular}{|c|c|c|c|c|c|c|c|c|}
\hline Invasive Species & $\begin{array}{l}\text { Threatened } \\
\text { Species }\end{array}$ & $\begin{array}{l}\text { Level of } \\
\text { threat }\end{array}$ & $\begin{array}{l}\text { Direction } \\
\text { of Impact }\end{array}$ & Mechanism & Location & Study design & $\begin{array}{l}\text { Study } \\
\text { design } \\
\text { score }\end{array}$ & Reference \\
\hline $\begin{array}{l}\text { Rhinocyllus } \\
\text { conicus }\end{array}$ & Cirsium pitcheri & Threatened & Negative & $\begin{array}{l}\text { Herbivory/grazing/browsin } \\
\text { g of immature plants }\end{array}$ & $\begin{array}{l}\text { Canada, } \\
\text { Alberta }\end{array}$ & $\begin{array}{l}\text { Observation } \\
\text { experimenta } \\
\text { I }\end{array}$ & 75 & $\begin{array}{l}\text { Louda et al. } \\
\text { (2005) }\end{array}$ \\
\hline $\begin{array}{l}\text { Rhizophora } \\
\text { mangle }\end{array}$ & $\begin{array}{l}\text { Himantopus } \\
\text { mexicanus } \\
\text { knudseni }\end{array}$ & Endangered & Negative & $\begin{array}{l}\text { Competition monopolising } \\
\text { resources, shelter/habitat }\end{array}$ & US, Hawaii & $\begin{array}{l}\text { Observation } \\
\text { experimenta } \\
\text { I }\end{array}$ & 73 & Morin (1998) \\
\hline $\begin{array}{l}\text { Rhizophora } \\
\text { mangle }\end{array}$ & Fulica alai & Endangered & Negative & $\begin{array}{l}\text { Competition monopolising } \\
\text { resources, shelter/habitat }\end{array}$ & US, Hawaii & $\begin{array}{l}\text { Observation } \\
\text { experimenta } \\
\text { I }\end{array}$ & 73 & Morin (1998) \\
\hline Salmo trutta & Salmo salar & Endangered & Negative & $\begin{array}{l}\text { Behaviour disruption, } \\
\text { feeding disruption }\end{array}$ & $\begin{array}{l}\text { Lab } \\
\text { experiment }\end{array}$ & RCT, ex-situ & 89 & $\begin{array}{l}\text { Van Zwol et al. } \\
(2012)\end{array}$ \\
\hline
\end{tabular}




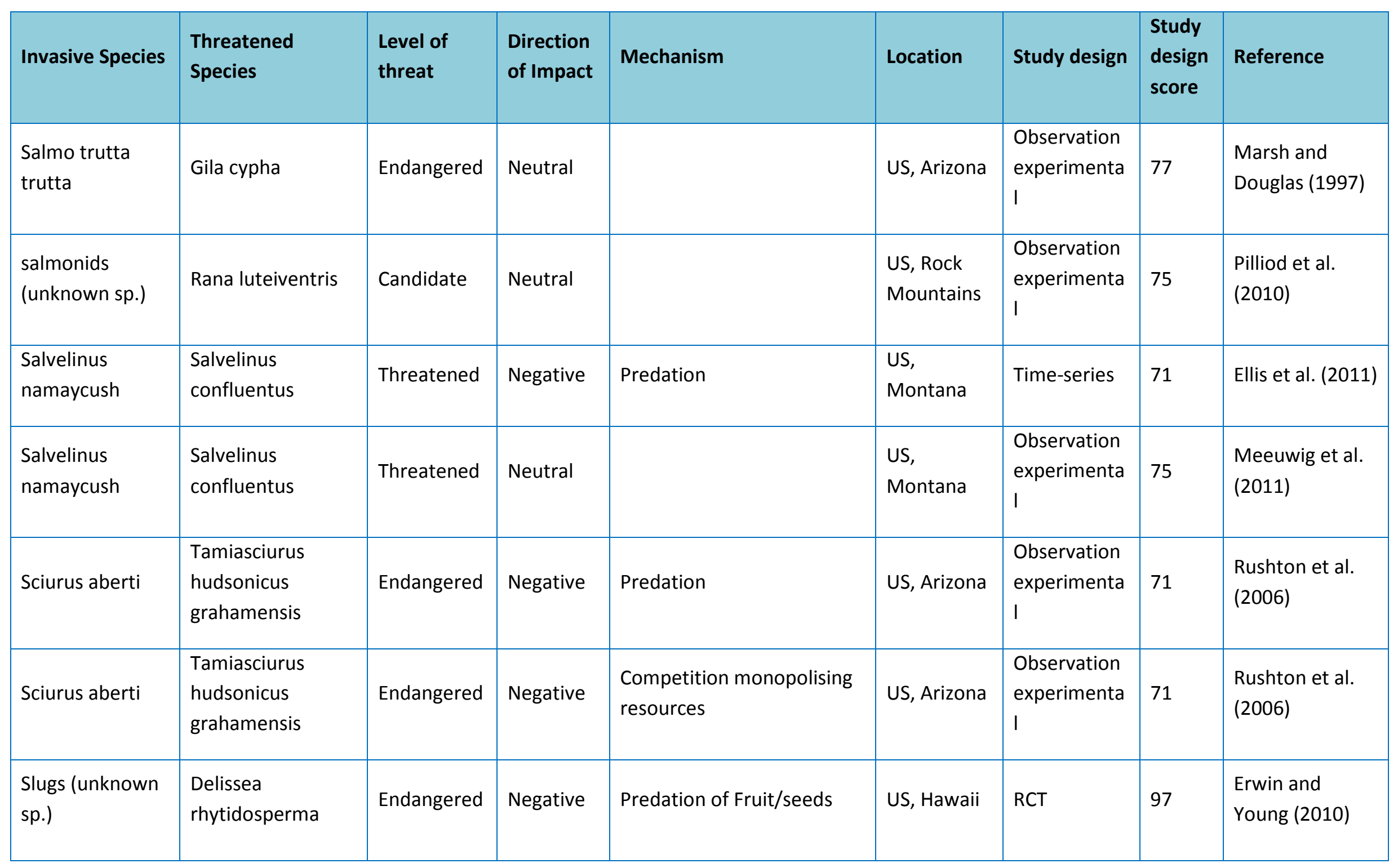




\begin{tabular}{|c|c|c|c|c|c|c|c|c|}
\hline Invasive Species & $\begin{array}{l}\text { Threatened } \\
\text { Species }\end{array}$ & $\begin{array}{l}\text { Level of } \\
\text { threat }\end{array}$ & $\begin{array}{l}\text { Direction } \\
\text { of Impact }\end{array}$ & Mechanism & Location & Study design & $\begin{array}{l}\text { Study } \\
\text { design } \\
\text { score }\end{array}$ & Reference \\
\hline $\begin{array}{l}\text { Solenopsis } \\
\text { invicta }\end{array}$ & Caretta caretta & Threatened & Negative & Predation of eggs & US, Georgia & $\begin{array}{l}\text { Observation } \\
\text { experimenta } \\
\text { I }\end{array}$ & 75 & $\begin{array}{l}\text { Diffie et al. } \\
\text { (2010) }\end{array}$ \\
\hline $\begin{array}{l}\text { Solenopsis } \\
\text { invicta }\end{array}$ & $\begin{array}{l}\text { Aphelocoma } \\
\text { coerulescens }\end{array}$ & Threatened & Negative & Predation of juveniles & US, Florida & Observation & 63 & $\begin{array}{l}\text { Wilcoxen and } \\
\text { Rensel (2009) }\end{array}$ \\
\hline Strix varia & $\begin{array}{l}\text { Strix occidentalis } \\
\text { caurina }\end{array}$ & Threatened & Negative & $\begin{array}{l}\text { Competition monopolising } \\
\text { resources, breeding sites }\end{array}$ & US, Oregon & Time-series & 77 & $\begin{array}{l}\text { Dugger et al. } \\
\text { (2011) }\end{array}$ \\
\hline Sus scrofa & $\begin{array}{l}\text { Pterodroma } \\
\text { phaeopygia } \\
\text { sandwichensis }\end{array}$ & Endangered & Negative & Predation of juveniles & $\begin{array}{l}\text { Ecuador, } \\
\text { Galapagos } \\
\text { Islands }\end{array}$ & Observation & 55 & $\begin{array}{l}\text { Cruz and Cruz } \\
\text { (1987) }\end{array}$ \\
\hline Sus scrofa & $\begin{array}{l}\text { Pterodroma } \\
\text { phaeopygia }\end{array}$ & Endangered & Neutral & & $\begin{array}{l}\text { Ecuador, } \\
\text { Galapagos } \\
\text { Islands }\end{array}$ & Observation & 69 & $\begin{array}{l}\text { Cruz-Delgado et } \\
\text { al. (2010) }\end{array}$ \\
\hline
\end{tabular}




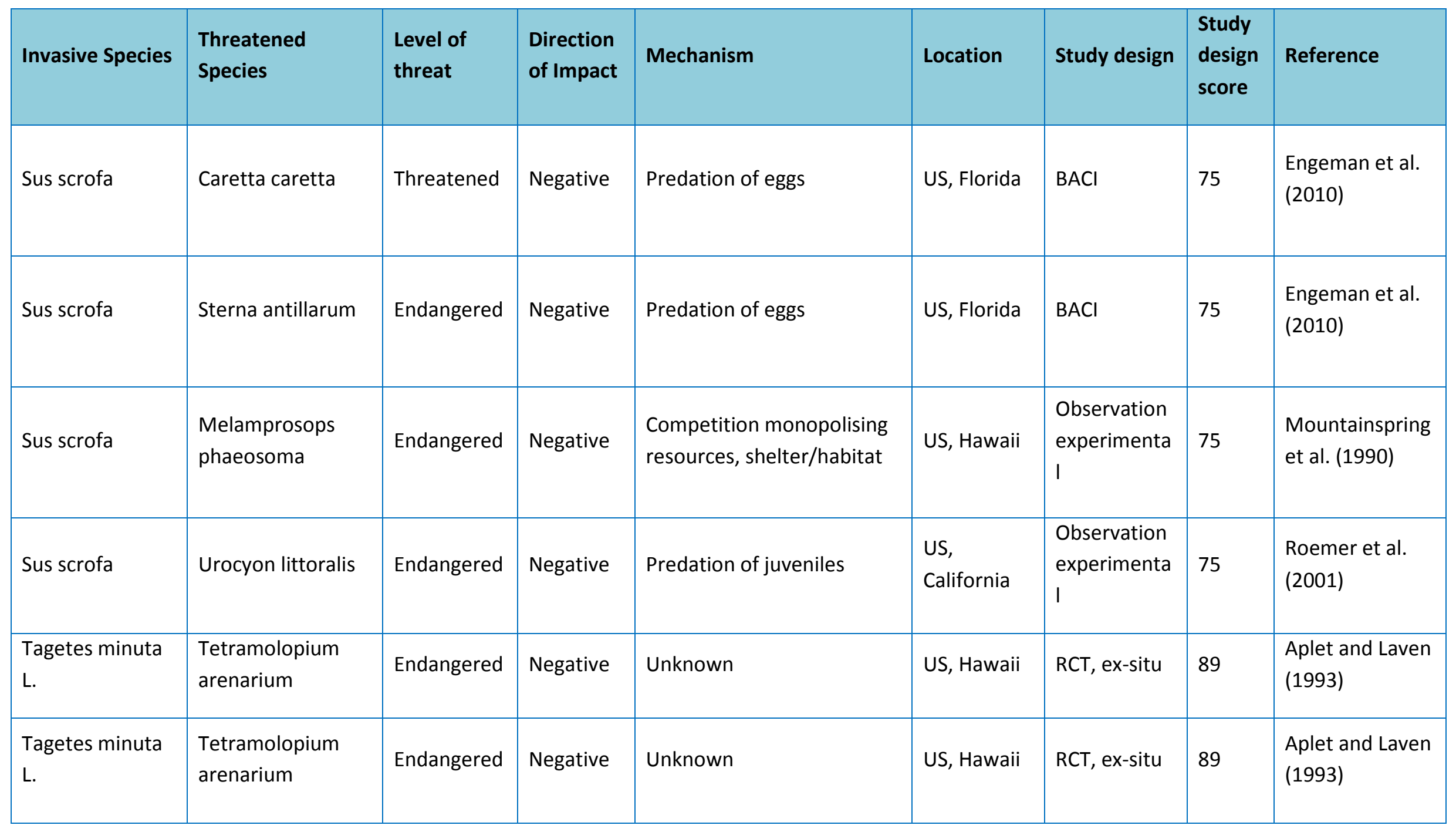




\begin{tabular}{|c|c|c|c|c|c|c|c|c|}
\hline Invasive Species & $\begin{array}{l}\text { Threatened } \\
\text { Species }\end{array}$ & $\begin{array}{l}\text { Level of } \\
\text { threat }\end{array}$ & $\begin{array}{l}\text { Direction } \\
\text { of Impact }\end{array}$ & Mechanism & Location & Study design & $\begin{array}{l}\text { Study } \\
\text { design } \\
\text { score }\end{array}$ & Reference \\
\hline $\begin{array}{l}\text { Tamarix } \\
\text { ramosissima }\end{array}$ & $\begin{array}{l}\text { Rhinichthys } \\
\text { osculus } \\
\text { nevadensis }\end{array}$ & Endangered & Negative & Competition shading & US, Nevada & $\mathrm{BACl}$ & 75 & $\begin{array}{l}\text { Kennedy et al. } \\
\text { (2005) }\end{array}$ \\
\hline $\begin{array}{l}\text { Tamarix } \\
\text { ramosissima }\end{array}$ & $\begin{array}{l}\text { Cyprinodon } \\
\text { nevadensis } \\
\text { mionectes }\end{array}$ & Endangered & Negative & Competition shading & US, Nevada & $\mathrm{BACl}$ & 75 & $\begin{array}{l}\text { Kennedy et al. } \\
\text { (2005) }\end{array}$ \\
\hline $\begin{array}{l}\text { Tamarix } \\
\text { ramosissima }\end{array}$ & $\begin{array}{l}\text { Empidonax traillii } \\
\text { extimus }\end{array}$ & Endangered & Negative & & US, Nevada & $\begin{array}{l}\text { Site } \\
\text { comparison }\end{array}$ & 67 & $\begin{array}{l}\text { Shanahan et al. } \\
\text { (2011) }\end{array}$ \\
\hline $\begin{array}{l}\text { Toxoptera } \\
\text { aurantii }\end{array}$ & $\begin{array}{l}\text { Gardenia } \\
\text { brighamii }\end{array}$ & Endangered & Negative & $\begin{array}{l}\text { Herbivory/grazing/browsin } \\
\mathrm{g} \text { of mature plants }\end{array}$ & US, Hawaii & Observation & 63 & $\begin{array}{l}\text { Messing et al. } \\
(2007)\end{array}$ \\
\hline $\begin{array}{l}\text { Trout (unknown } \\
\text { sp.) }\end{array}$ & Rana muscosa & Endangered & Negative & Predation of juveniles & $\begin{array}{l}\text { US, } \\
\text { California }\end{array}$ & $\mathrm{BACl}$ & 79 & $\begin{array}{l}\text { Finlay and } \\
\text { Vredenburg } \\
\text { (2007) }\end{array}$ \\
\hline
\end{tabular}




\begin{tabular}{|c|c|c|c|c|c|c|c|c|}
\hline Invasive Species & $\begin{array}{l}\text { Threatened } \\
\text { Species }\end{array}$ & $\begin{array}{l}\text { Level of } \\
\text { threat }\end{array}$ & $\begin{array}{l}\text { Direction } \\
\text { of Impact }\end{array}$ & Mechanism & Location & Study design & $\begin{array}{l}\text { Study } \\
\text { design } \\
\text { score }\end{array}$ & Reference \\
\hline $\begin{array}{l}\text { Trout (unknown } \\
\text { sp.) }\end{array}$ & Rana muscosa & Endangered & Negative & $\begin{array}{l}\text { Competition monopolising } \\
\text { resources, food/nutrients }\end{array}$ & $\begin{array}{l}\text { US, } \\
\text { California }\end{array}$ & $\begin{array}{l}\text { Observation } \\
\text { experimenta } \\
\text { I }\end{array}$ & 79 & $\begin{array}{l}\text { Finlay and } \\
\text { Vredenburg } \\
\text { (2007) }\end{array}$ \\
\hline Xenopus laevis & $\begin{array}{l}\text { Eucyclogobius } \\
\text { newberryi }\end{array}$ & Endangered & Negative & Predation & $\begin{array}{l}\text { US, } \\
\text { California }\end{array}$ & $\begin{array}{l}\text { Observation } \\
\text { experimenta } \\
\text { I }\end{array}$ & 75 & $\begin{array}{l}\text { Lafferty and } \\
\text { Page (1997) }\end{array}$ \\
\hline $\begin{array}{l}\text { Zosterops } \\
\text { japonicus }\end{array}$ & $\begin{array}{l}\text { Nothocestrum } \\
\text { latifolium }\end{array}$ & Candidate & Negative & $\begin{array}{l}\text { Interaction with other } \\
\text { invasive species }\end{array}$ & US, Hawaii & $\begin{array}{l}\text { Observation } \\
\text { experimenta } \\
\text { I }\end{array}$ & 70 & $\begin{array}{l}\text { Chimera and } \\
\text { Drake (2010) }\end{array}$ \\
\hline $\begin{array}{l}\text { Zosterops } \\
\text { japonicus }\end{array}$ & $\begin{array}{l}\text { Loxops coccineus } \\
\text { coccineus }\end{array}$ & Endangered & Negative & $\begin{array}{l}\text { Competition monopolising } \\
\text { resources, food/nutrients }\end{array}$ & US, Hawaii & Time-series & & $\begin{array}{l}\text { Freed and Cann } \\
\text { (2009) }\end{array}$ \\
\hline $\begin{array}{l}\text { Zosterops } \\
\text { japonicus }\end{array}$ & Oreomystis mana & Endangered & Negative & $\begin{array}{l}\text { Competition monopolising } \\
\text { resources, food/nutrients }\end{array}$ & US, Hawaii & Time-series & & $\begin{array}{l}\text { Freed. and Cann } \\
\text { (2009) }\end{array}$ \\
\hline $\begin{array}{l}\text { Zosterops } \\
\text { japonicus }\end{array}$ & $\begin{array}{l}\text { Loxops coccineus } \\
\text { coccineus }\end{array}$ & Endangered & Negative & $\begin{array}{l}\text { Competition monopolising } \\
\text { resources, shelter/habitat }\end{array}$ & US, Hawaii & Time-series & 77 & $\begin{array}{l}\text { Freed et al. } \\
\text { (2008) }\end{array}$ \\
\hline $\begin{array}{l}\text { Zosterops } \\
\text { japonicus }\end{array}$ & $\begin{array}{l}\text { Loxops coccineus } \\
\text { coccineus }\end{array}$ & Endangered & Negative & $\begin{array}{l}\text { Competition monopolising } \\
\text { resources, food/nutrients }\end{array}$ & US, Hawaii & Time-series & 73 & $\begin{array}{l}\text { Freed and Cann } \\
\text { (2012) }\end{array}$ \\
\hline $\begin{array}{l}\text { Zosterops } \\
\text { japonicus }\end{array}$ & Oreomystis mana & Endangered & Negative & $\begin{array}{l}\text { Competition monopolising } \\
\text { resources, food/nutrients }\end{array}$ & US, Hawaii & Time-series & 73 & $\begin{array}{l}\text { Freed and Cann } \\
\text { (2012) }\end{array}$ \\
\hline
\end{tabular}




\begin{tabular}{|l|l|l|l|l|l|l|l|l|}
\hline Invasive Species & $\begin{array}{l}\text { Threatened } \\
\text { Species }\end{array}$ & $\begin{array}{l}\text { Level of } \\
\text { threat }\end{array}$ & $\begin{array}{l}\text { Direction } \\
\text { of Impact }\end{array}$ & Mechanism & Location & Study design & $\begin{array}{l}\text { Study } \\
\text { design } \\
\text { score }\end{array}$ & Reference \\
\hline $\begin{array}{l}\text { Zosterops } \\
\text { japonicus }\end{array}$ & $\begin{array}{l}\text { Hemignathus } \\
\text { munroi }\end{array}$ & Endangered & Negative & $\begin{array}{l}\text { Competition monopolising } \\
\text { resources, food/nutrients }\end{array}$ & US, Hawaii & Time-series & 73 & $\begin{array}{l}\text { Freed and Cann } \\
(2012)\end{array}$ \\
\hline & & & & & \\
\hline
\end{tabular}

\section{Appendix Four: Data presented by Threatened species}

\begin{tabular}{|c|c|c|c|c|c|c|c|c|}
\hline $\begin{array}{l}\text { Threatened } \\
\text { Species }\end{array}$ & Invasive Species & Level of threat & $\begin{array}{l}\text { Direction } \\
\text { of Impact }\end{array}$ & Mechanism & Location & Study design & $\begin{array}{l}\text { Study } \\
\text { design } \\
\text { score }\end{array}$ & Reference \\
\hline $\begin{array}{l}\text { Abutilon } \\
\text { menziesii }\end{array}$ & Aphis gossypii & Endangered & Negative & $\begin{array}{l}\text { Herbivory/grazing } \\
\text { /browsing of mature plants }\end{array}$ & US, Hawaii & Observation & 63 & $\begin{array}{l}\text { Messing et al. } \\
(2007)\end{array}$ \\
\hline $\begin{array}{l}\text { Agelaius } \\
\text { xanthomus }\end{array}$ & $\begin{array}{l}\text { Molothrus } \\
\text { bonariensis }\end{array}$ & Endangered & Negative & Parasitism & $\begin{array}{l}\text { US, Puerto } \\
\text { Rico }\end{array}$ & $\begin{array}{l}\text { Observation } \\
\text { experimental }\end{array}$ & 77 & $\begin{array}{l}\text { Wiley et al. } \\
(1991)\end{array}$ \\
\hline $\begin{array}{l}\text { Alsinidendron } \\
\text { obovatum }\end{array}$ & Deroceras laeve & Endangered & Negative & & US, Hawaii & $\mathrm{RCT}$ & 94 & $\begin{array}{l}\text { Joe and } \\
\text { Daehler }\end{array}$ \\
\hline
\end{tabular}




\begin{tabular}{|c|c|c|c|c|c|c|c|c|}
\hline $\begin{array}{l}\text { Threatened } \\
\text { Species }\end{array}$ & Invasive Species & Level of threat & $\begin{array}{l}\text { Direction } \\
\text { of Impact }\end{array}$ & Mechanism & Location & Study design & $\begin{array}{l}\text { Study } \\
\text { design } \\
\text { score }\end{array}$ & Reference \\
\hline $\begin{array}{l}\text { Alsinidendron } \\
\text { obovatum }\end{array}$ & Limacus flavus & Endangered & Negative & & US, Hawaii & RCT & 94 & $\begin{array}{l}\text { Joe and } \\
\text { Daehler } \\
\text { (2008) }\end{array}$ \\
\hline $\begin{array}{l}\text { Alsinidendron } \\
\text { obovatum }\end{array}$ & Limax maximus & Endangered & Negative & & US, Hawaii & RCT & 94 & $\begin{array}{l}\text { Joe and } \\
\text { Daehler } \\
\text { (2008) }\end{array}$ \\
\hline $\begin{array}{l}\text { Alsinidendron } \\
\text { obovatum }\end{array}$ & $\begin{array}{l}\text { Meghimatium } \\
\text { striatum }\end{array}$ & Endangered & Negative & & US, Hawaii & RCT & 94 & $\begin{array}{l}\text { Joe and } \\
\text { Daehler } \\
\text { (2008) }\end{array}$ \\
\hline Amazona vittata & $\begin{array}{l}\text { Herpestes } \\
\text { javanicus }\end{array}$ & Endangered & Negative & Predation & $\begin{array}{l}\text { Puerto } \\
\text { Rico, Sierra } \\
\text { de Luquillo } \\
\text { Mountains }\end{array}$ & Observation & 55 & $\begin{array}{l}\text { Engeman et } \\
\text { al. (2006) }\end{array}$ \\
\hline
\end{tabular}




\begin{tabular}{|c|c|c|c|c|c|c|c|c|}
\hline $\begin{array}{l}\text { Threatened } \\
\text { Species }\end{array}$ & Invasive Species & Level of threat & $\begin{array}{l}\text { Direction } \\
\text { of Impact }\end{array}$ & Mechanism & Location & Study design & $\begin{array}{l}\text { Study } \\
\text { design } \\
\text { score }\end{array}$ & Reference \\
\hline Amazona vittata & Rattus rattus & Endangered & Negative & Predation & $\begin{array}{l}\text { Puerto } \\
\text { Rico, Sierra } \\
\text { de Luquillo } \\
\text { Mountains }\end{array}$ & Observation & 55 & $\begin{array}{l}\text { Engeman et } \\
\text { al. (2006) }\end{array}$ \\
\hline $\begin{array}{l}\text { Ambystoma } \\
\text { californiense }\end{array}$ & $\begin{array}{l}\text { Ambystoma } \\
\text { tigrinum } \\
\text { mavortium }\end{array}$ & Threatened & Negative & Hybridisation & $\begin{array}{l}\text { US, } \\
\text { California }\end{array}$ & $\begin{array}{l}\text { Observation } \\
\text { experimental }\end{array}$ & 75 & $\begin{array}{l}\text { Fitzpatrick } \\
\text { and Shaffer } \\
\text { (2007) }\end{array}$ \\
\hline $\begin{array}{l}\text { Ambystoma } \\
\text { californiense }\end{array}$ & $\begin{array}{l}\text { Ambystoma } \\
\text { tigrinum } \\
\text { mavortium }\end{array}$ & Threatened & Positive & Hybridisation & $\begin{array}{l}\text { US, } \\
\text { California }\end{array}$ & $\begin{array}{l}\text { Observation } \\
\text { experimental }\end{array}$ & 75 & $\begin{array}{l}\text { Fitzpatrick et } \\
\text { al. (2010) }\end{array}$ \\
\hline $\begin{array}{l}\text { Ambystoma } \\
\text { californiense }\end{array}$ & $\begin{array}{l}\text { Ambystoma } \\
\text { tigrinum } \\
\text { mavortium }\end{array}$ & Endangered & Negative & $\begin{array}{l}\text { Competition monopolising } \\
\text { resources }\end{array}$ & $\begin{array}{l}\text { US, } \\
\text { California }\end{array}$ & $\mathrm{BACl}$ & 79 & $\begin{array}{l}\text { Ryan et al. } \\
\text { (2009) }\end{array}$ \\
\hline $\begin{array}{l}\text { Ambystoma } \\
\text { californiense }\end{array}$ & $\begin{array}{l}\text { Ambystoma } \\
\text { tigrinum } \\
\text { mavortium }\end{array}$ & Endangered & Negative & Predation & $\begin{array}{l}\text { US, } \\
\text { California }\end{array}$ & $\mathrm{BACl}$ & 79 & $\begin{array}{l}\text { Ryan et al. } \\
\text { (2009) }\end{array}$ \\
\hline $\begin{array}{l}\text { Ambystoma } \\
\text { tigrinum } \\
\text { stebbinsi }\end{array}$ & Ameiurus melas & Endangered & Negative & & US, Arizona & $\begin{array}{l}\text { Interrupted } \\
\text { time-series }\end{array}$ & 61 & $\begin{array}{l}\text { Maret et al. } \\
(2006)\end{array}$ \\
\hline
\end{tabular}




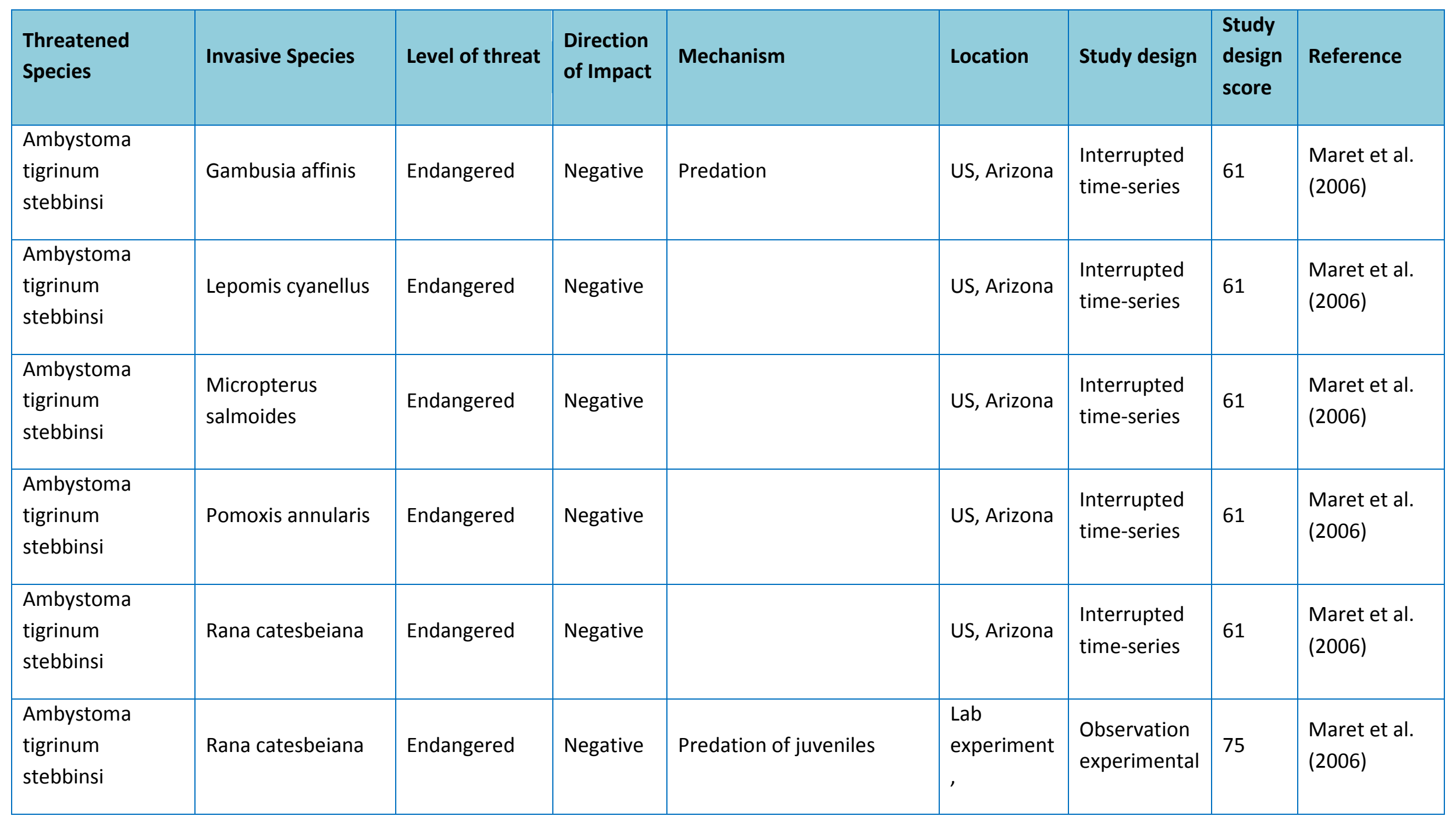




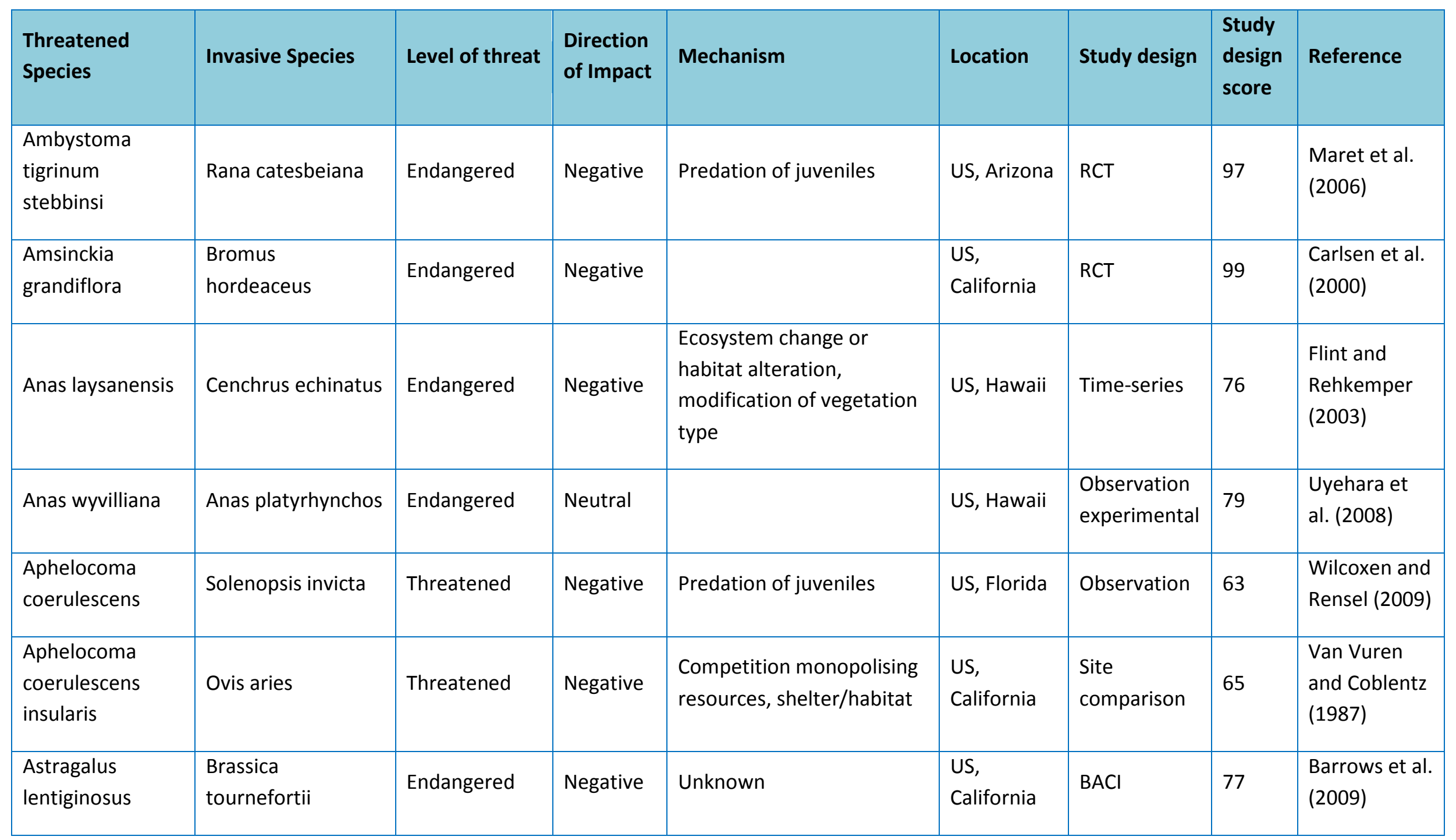




\begin{tabular}{|c|c|c|c|c|c|c|c|c|}
\hline $\begin{array}{l}\text { Threatened } \\
\text { Species }\end{array}$ & Invasive Species & Level of threat & $\begin{array}{l}\text { Direction } \\
\text { of Impact }\end{array}$ & Mechanism & Location & Study design & $\begin{array}{l}\text { Study } \\
\text { design } \\
\text { score }\end{array}$ & Reference \\
\hline Caretta caretta & Canis familiaris & Threatened & Negative & $\begin{array}{l}\text { Predation of mature } \\
\text { animals }\end{array}$ & $\begin{array}{l}\text { Brazil, } \\
\text { Bahia }\end{array}$ & Observation & 62 & $\begin{array}{l}\text { Santos and } \\
\text { Godfrey } \\
(2001)\end{array}$ \\
\hline Caretta caretta & Solenopsis invicta & Threatened & Negative & Predation of eggs & US, Georgia & $\begin{array}{l}\text { Observation } \\
\text { experimental }\end{array}$ & 75 & $\begin{array}{l}\text { Diffie et al. } \\
(2010)\end{array}$ \\
\hline Castilleja mollis & Cervus elaphus & Endangered & Negative & Rooting or digging & $\begin{array}{l}\text { US, } \\
\text { California }\end{array}$ & Time-series & 77 & $\begin{array}{l}\text { McEachern } \\
\text { et al. (2009) }\end{array}$ \\
\hline Castilleja mollis & Cervus elaphus & Endangered & Negative & $\begin{array}{l}\text { Herbivory or grazing or } \\
\text { browsing }\end{array}$ & $\begin{array}{l}\text { US, } \\
\text { California }\end{array}$ & Time-series & 77 & $\begin{array}{l}\text { McEachern } \\
\text { et al. (2009) }\end{array}$ \\
\hline
\end{tabular}




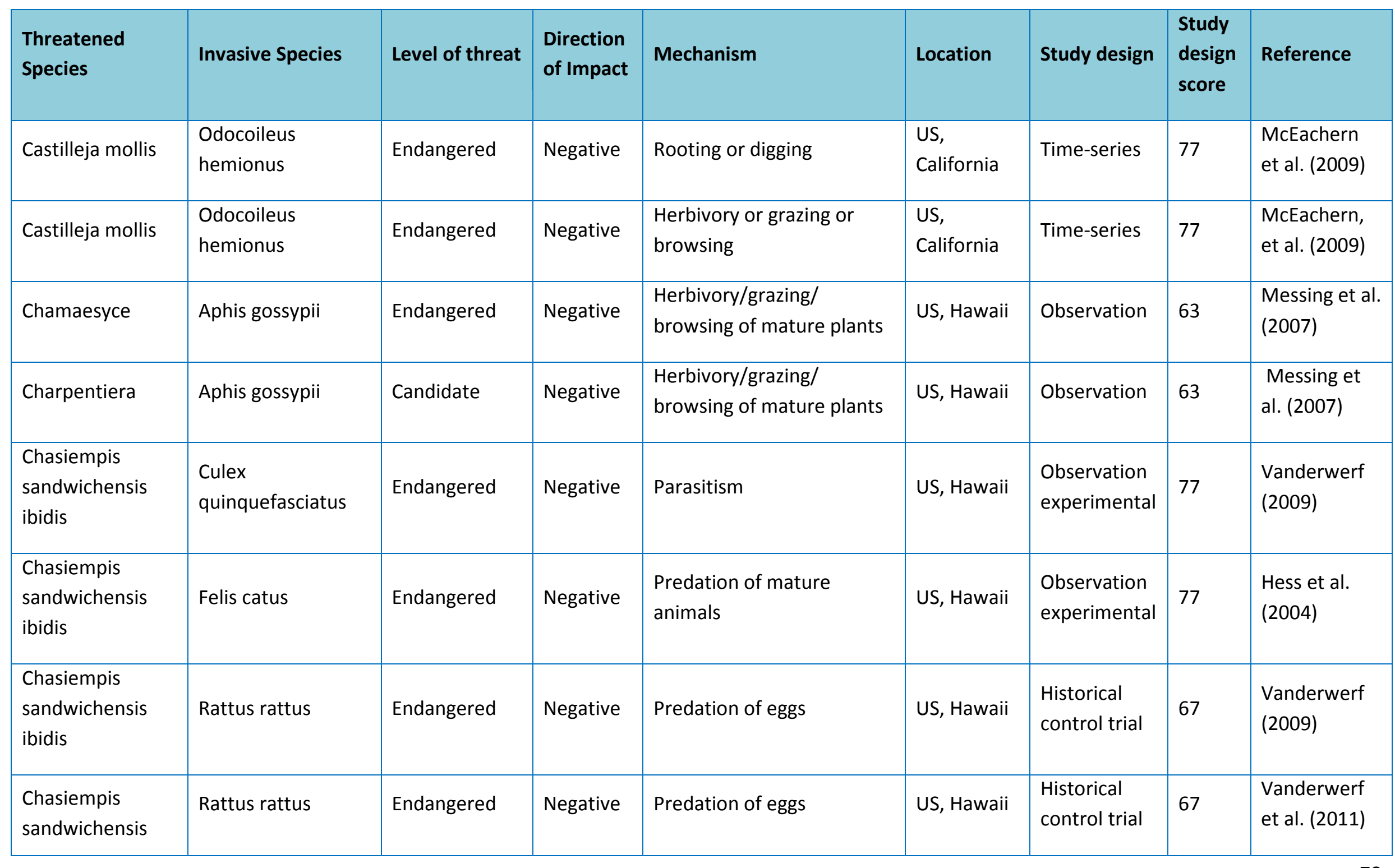




\begin{tabular}{|c|c|c|c|c|c|c|c|c|}
\hline $\begin{array}{l}\text { Threatened } \\
\text { Species }\end{array}$ & Invasive Species & Level of threat & $\begin{array}{l}\text { Direction } \\
\text { of Impact }\end{array}$ & Mechanism & Location & Study design & $\begin{array}{l}\text { Study } \\
\text { design } \\
\text { score }\end{array}$ & Reference \\
\hline Chelonia mydas & $\begin{array}{l}\text { Hypnea } \\
\text { musciformis }\end{array}$ & Threatened & Positive & & US, Hawaii & $\begin{array}{l}\text { Observation } \\
\text { experimental }\end{array}$ & 70 & $\begin{array}{l}\text { Russell and. } \\
\text { Balazs (1994) }\end{array}$ \\
\hline Chelonia mydas & Rattus rattus & Endangered & Negative & Predation of juveniles & $\begin{array}{l}\text { New } \\
\text { Caledonia, } \\
\text { Surprise } \\
\text { Island }\end{array}$ & Observation & 67 & $\begin{array}{l}\text { Caut et al. } \\
(2008)\end{array}$ \\
\hline Cirsium pitcheri & Rhinocyllus conicus & Threatened & Negative & $\begin{array}{l}\text { Herbivory/grazing/ } \\
\text { browsing of immature } \\
\text { plants }\end{array}$ & $\begin{array}{l}\text { US, } \\
\text { Nebraska }\end{array}$ & RCT, ex-situ & 89 & $\begin{array}{l}\text { Louda et al. } \\
\text { (2005) }\end{array}$ \\
\hline Cirsium pitcheri & Rhinocyllus conicus & Threatened & Negative & $\begin{array}{l}\text { Herbivory/grazing } \\
\text { /browsing of immature } \\
\text { plants }\end{array}$ & $\begin{array}{l}\text { Canada, } \\
\text { Alberta }\end{array}$ & $\begin{array}{l}\text { Observation } \\
\text { experimental }\end{array}$ & 75 & $\begin{array}{l}\text { Louda et al. } \\
\text { (2005) }\end{array}$ \\
\hline
\end{tabular}




\begin{tabular}{|c|c|c|c|c|c|c|c|c|}
\hline $\begin{array}{l}\text { Threatened } \\
\text { Species }\end{array}$ & Invasive Species & Level of threat & $\begin{array}{l}\text { Direction } \\
\text { of Impact }\end{array}$ & Mechanism & Location & Study design & $\begin{array}{l}\text { Study } \\
\text { design } \\
\text { score }\end{array}$ & Reference \\
\hline Cirsium vinaceum & Dipsacus sylvestris & Threatened & Negative & & $\begin{array}{l}\text { US, New } \\
\text { Mexico }\end{array}$ & $\mathrm{BACl}$ & 77 & $\begin{array}{l}\text { Huenneke } \\
\text { and Thomson } \\
\text { (1995) }\end{array}$ \\
\hline Cirsium vinaceum & Dipsacus sylvestris & Threatened & Neutral & & $\begin{array}{l}\text { US, New } \\
\text { Mexico }\end{array}$ & $\mathrm{BACl}$ & 77 & $\begin{array}{l}\text { Huenneke } \\
\text { and Thomson } \\
\text { (1995) }\end{array}$ \\
\hline $\begin{array}{l}\text { Coccyzus } \\
\text { americanus }\end{array}$ & $\begin{array}{l}\text { Liquidambar } \\
\text { styraciflua }\end{array}$ & Candidate & Neutral & $\begin{array}{l}\text { Behaviour disruption, } \\
\text { feeding disruption }\end{array}$ & US, Georgia & $\begin{array}{l}\text { Site } \\
\text { comparison }\end{array}$ & 67 & $\begin{array}{l}\text { Klaus and } \\
\text { Keyes (2007) }\end{array}$ \\
\hline $\begin{array}{l}\text { Coccyzus } \\
\text { americanus }\end{array}$ & $\begin{array}{l}\text { Microstegium } \\
\text { vimineum }\end{array}$ & Candidate & Negative & Unknown & $\begin{array}{l}\text { US, New } \\
\text { Jersey }\end{array}$ & $\begin{array}{l}\text { Interrupted } \\
\text { time-series }\end{array}$ & 60 & $\begin{array}{l}\text { Baiser et al. } \\
\text { (2008) }\end{array}$ \\
\hline $\begin{array}{l}\text { Coccyzus } \\
\text { americanus }\end{array}$ & Quercus nigra & Candidate & Neutral & $\begin{array}{l}\text { Behaviour disruption, } \\
\text { feeding disruption }\end{array}$ & US, Georgia & $\begin{array}{l}\text { Site } \\
\text { comparison }\end{array}$ & 67 & $\begin{array}{l}\text { Klaus and } \\
\text { Keyes (2007) }\end{array}$ \\
\hline $\begin{array}{l}\text { Colubrina } \\
\text { oppositifolia }\end{array}$ & $\begin{array}{l}\text { Pennisetum } \\
\text { setaceum }\end{array}$ & Endangered & Neutral & & US, Hawaii & RCT, ex-situ & 89 & $\begin{array}{l}\text { Cabin et al. } \\
(2002)\end{array}$ \\
\hline $\begin{array}{l}\text { Colubrina } \\
\text { oppositifolia }\end{array}$ & $\begin{array}{l}\text { Pennisetum } \\
\text { setaceum }\end{array}$ & Endangered & Neutral & & US, Hawaii & $\mathrm{RCT}$ & 99 & $\begin{array}{l}\text { Cabin et al. } \\
(2002)\end{array}$ \\
\hline
\end{tabular}




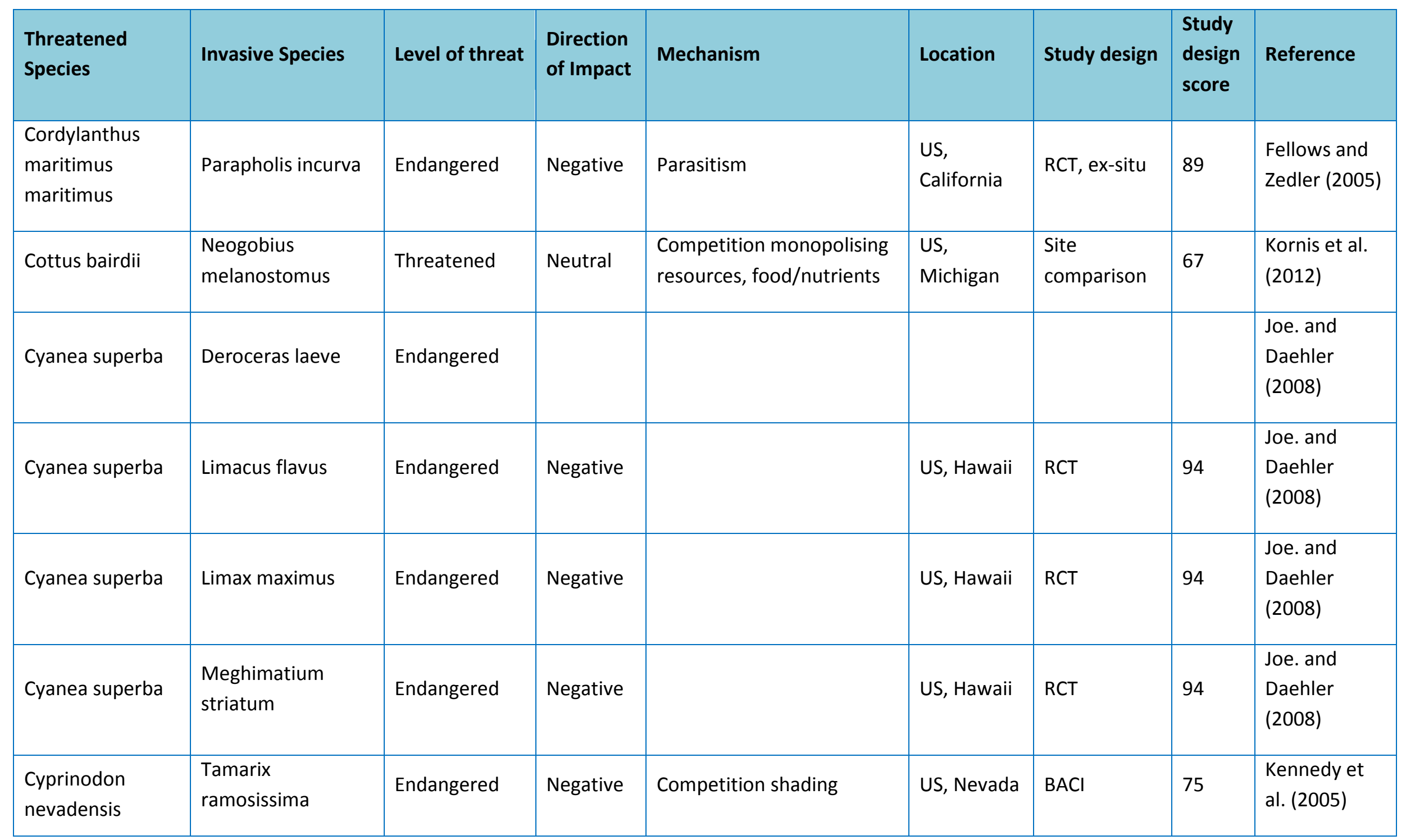




\begin{tabular}{|c|c|c|c|c|c|c|c|c|}
\hline $\begin{array}{l}\text { Threatened } \\
\text { Species }\end{array}$ & Invasive Species & Level of threat & $\begin{array}{l}\text { Direction } \\
\text { of Impact }\end{array}$ & Mechanism & Location & Study design & $\begin{array}{l}\text { Study } \\
\text { design } \\
\text { score }\end{array}$ & Reference \\
\hline $\begin{array}{l}\text { Delissea } \\
\text { rhytidosperma }\end{array}$ & $\begin{array}{l}\text { Carabid beetles } \\
\text { (unknown sp.) }\end{array}$ & Endangered & Negative & Predation of Fruit/seeds & US, Hawaii & RCT & 97 & $\begin{array}{l}\text { Erwin and } \\
\text { Young (2010) }\end{array}$ \\
\hline $\begin{array}{l}\text { Delissea } \\
\text { rhytidosperma }\end{array}$ & $\begin{array}{l}\text { Oplismenus } \\
\text { hirtellus }\end{array}$ & Endangered & Negative & Predation of Fruit/seeds & US, Hawaii & RCT & 97 & $\begin{array}{l}\text { Erwin and } \\
\text { Young (2010) }\end{array}$ \\
\hline $\begin{array}{l}\text { Delissea } \\
\text { rhytidosperma }\end{array}$ & $\begin{array}{l}\text { Rattus (unknown } \\
\text { sp.) }\end{array}$ & Endangered & Negative & Predation of Fruit/seeds & US, Hawaii & RCT & 97 & $\begin{array}{l}\text { Erwin and } \\
\text { Young (2010) }\end{array}$ \\
\hline $\begin{array}{l}\text { Desmocerus } \\
\text { californicus } \\
\text { dimorphus }\end{array}$ & $\begin{array}{l}\text { Linepithema } \\
\text { humile }\end{array}$ & Threatened & Negative & & $\begin{array}{l}\text { US, } \\
\text { California }\end{array}$ & $\begin{array}{l}\text { Observation } \\
\text { experimental }\end{array}$ & 75 & Huxel (2000) \\
\hline $\begin{array}{l}\text { Desmocerus } \\
\text { californicus } \\
\text { dimorphus }\end{array}$ & $\begin{array}{l}\text { Linepithema } \\
\text { humile }\end{array}$ & Threatened & Neutral & & $\begin{array}{l}\text { US, } \\
\text { California }\end{array}$ & $\begin{array}{l}\text { Observation } \\
\text { experimental }\end{array}$ & 75 & Huxel (2000) \\
\hline
\end{tabular}




\begin{tabular}{|c|c|c|c|c|c|c|c|c|}
\hline $\begin{array}{l}\text { Threatened } \\
\text { Species }\end{array}$ & Invasive Species & Level of threat & $\begin{array}{l}\text { Direction } \\
\text { of Impact }\end{array}$ & Mechanism & Location & Study design & $\begin{array}{l}\text { Study } \\
\text { design } \\
\text { score }\end{array}$ & Reference \\
\hline Dudleya nesiotica & Ovis aries & Endangered & Positive & $\begin{array}{l}\text { Herbivory/grazing/ } \\
\text { browsing of mature plants }\end{array}$ & $\begin{array}{l}\text { US, } \\
\text { California }\end{array}$ & $\begin{array}{l}\text { Interrupted } \\
\text { time-series }\end{array}$ & 67 & $\begin{array}{l}\text { Klinger et al. } \\
(2003)\end{array}$ \\
\hline $\begin{array}{l}\text { Enhydra lutris } \\
\text { nereis }\end{array}$ & Taxoplasm gondii & Threatened & Negative & Predation & $\begin{array}{l}\text { US, } \\
\text { California }\end{array}$ & $\begin{array}{l}\text { Observation } \\
\text { experimental }\end{array}$ & 77 & $\begin{array}{l}\text { Miller et al. } \\
(2002)\end{array}$ \\
\hline $\begin{array}{l}\text { Epioblasma } \\
\text { triquetra }\end{array}$ & Dreissena bugensis & Endangered & Neutral & $\begin{array}{l}\text { Competition monopolising } \\
\text { resources, food/nutrients }\end{array}$ & $\begin{array}{l}\text { US, } \\
\text { Michigan }\end{array}$ & $\begin{array}{l}\text { Interrupted } \\
\text { time-series }\end{array}$ & 58 & $\begin{array}{l}\text { Schloesser et } \\
\text { al. (1998) }\end{array}$ \\
\hline $\begin{array}{l}\text { Epioblasma } \\
\text { triquetra }\end{array}$ & $\begin{array}{l}\text { Dreissena } \\
\text { polymorpha }\end{array}$ & Endangered & Neutral & $\begin{array}{l}\text { Competition monopolising } \\
\text { resources, food/nutrients }\end{array}$ & $\begin{array}{l}\text { US, } \\
\text { Michigan }\end{array}$ & $\begin{array}{l}\text { Interrupted } \\
\text { time-series }\end{array}$ & 58 & $\begin{array}{l}\text { Schloesser et } \\
\text { al. (1998) }\end{array}$ \\
\hline
\end{tabular}




\begin{tabular}{|c|c|c|c|c|c|c|c|c|}
\hline $\begin{array}{l}\text { Threatened } \\
\text { Species }\end{array}$ & Invasive Species & Level of threat & $\begin{array}{l}\text { Direction } \\
\text { of Impact }\end{array}$ & Mechanism & Location & Study design & $\begin{array}{l}\text { Study } \\
\text { design } \\
\text { score }\end{array}$ & Reference \\
\hline $\begin{array}{l}\text { Eucyclogobius } \\
\text { newberryi }\end{array}$ & Xenopus laevis & Endangered & Negative & Predation & $\begin{array}{l}\text { US, } \\
\text { California }\end{array}$ & $\begin{array}{l}\text { Observation } \\
\text { experimental }\end{array}$ & 75 & $\begin{array}{l}\text { Lafferty and } \\
\text { Page (1997) }\end{array}$ \\
\hline $\begin{array}{l}\text { Euphydryas } \\
\text { editha taylori }\end{array}$ & $\begin{array}{l}\text { Brachypodium } \\
\text { sylvaticum }\end{array}$ & Candidate & Neutral & $\begin{array}{l}\text { Behaviour disruption, } \\
\text { breeding disruption }\end{array}$ & US, Oregon & $\begin{array}{l}\text { Site } \\
\text { comparison }\end{array}$ & 67 & $\begin{array}{l}\text { Severns and } \\
\text { Warren } \\
(2008)\end{array}$ \\
\hline $\begin{array}{l}\text { Frankenia } \\
\text { johnstonii }\end{array}$ & $\begin{array}{l}\text { Diorhabda elongata } \\
\text { deserticola }\end{array}$ & Endangered & Neutral & $\begin{array}{l}\text { Herbivory/grazing/ } \\
\text { browsing of mature plants }\end{array}$ & $\begin{array}{l}\text { Lab } \\
\text { experiment }\end{array}$ & RCT, ex-situ & 89 & $\begin{array}{l}\text { Lewis et al. } \\
\text { (2003) }\end{array}$ \\
\hline
\end{tabular}




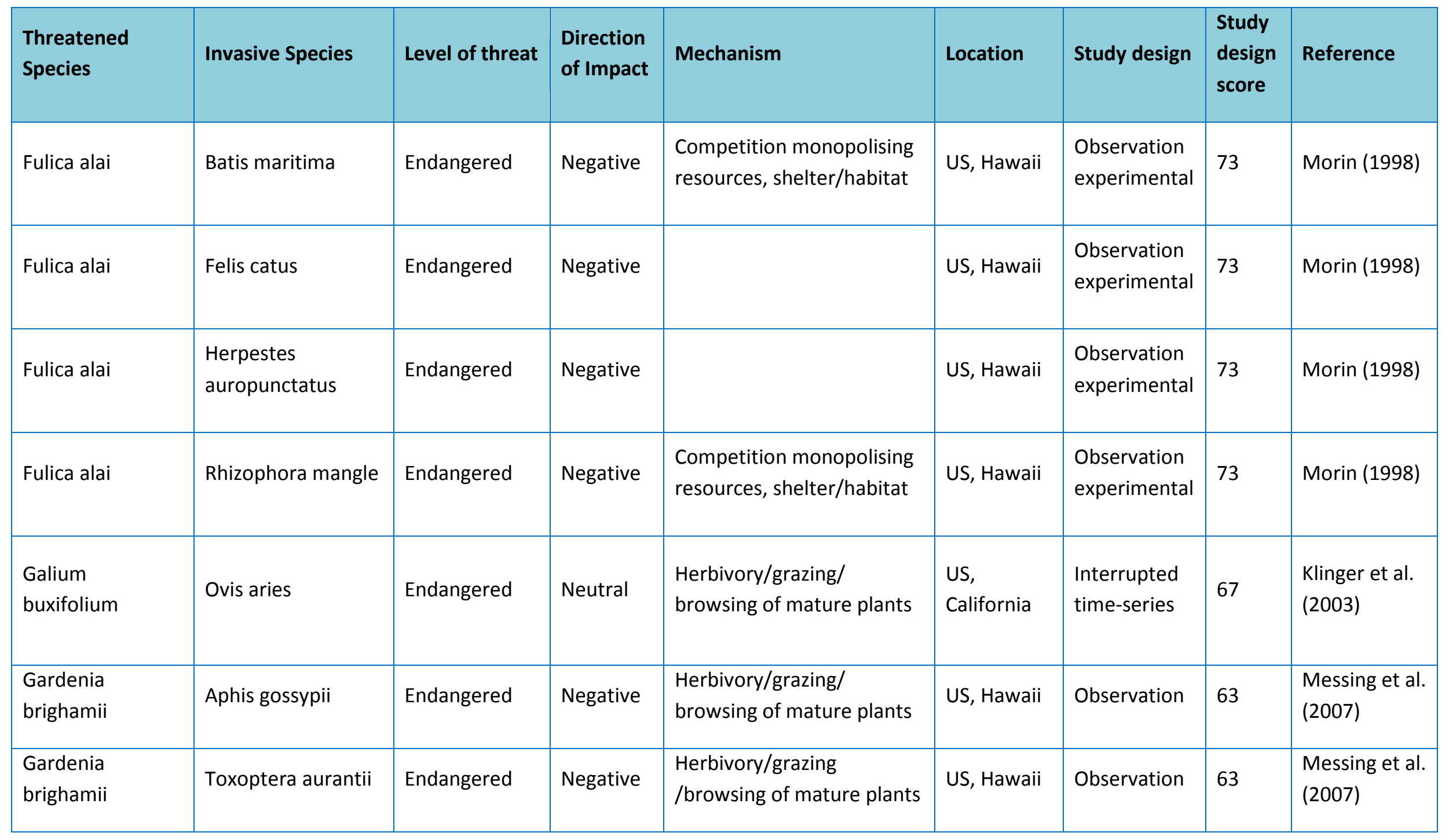




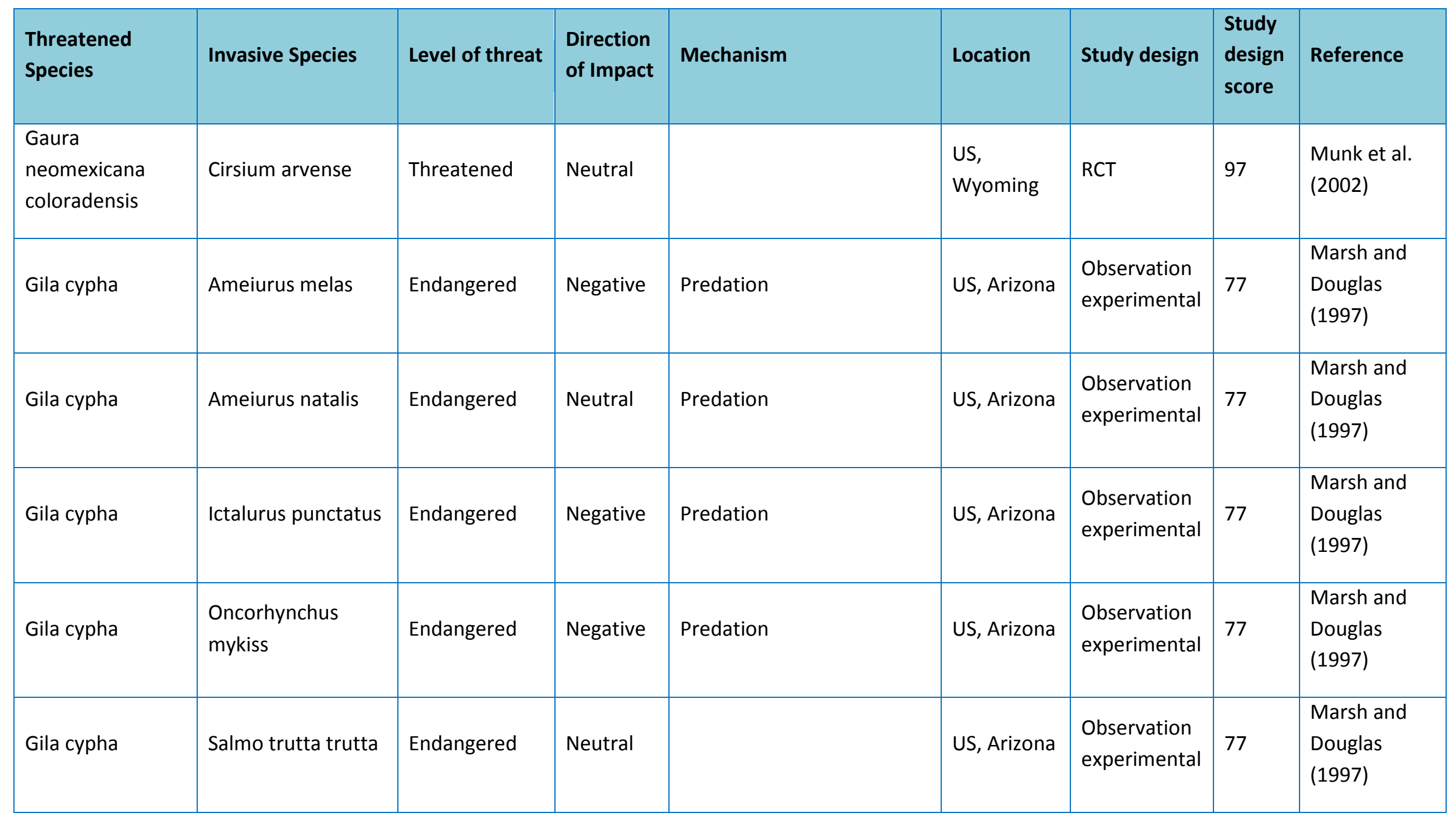




\begin{tabular}{|c|c|c|c|c|c|c|c|c|}
\hline $\begin{array}{l}\text { Threatened } \\
\text { Species }\end{array}$ & Invasive Species & Level of threat & $\begin{array}{l}\text { Direction } \\
\text { of Impact }\end{array}$ & Mechanism & Location & Study design & $\begin{array}{l}\text { Study } \\
\text { design } \\
\text { score }\end{array}$ & Reference \\
\hline $\begin{array}{l}\text { Hibiscus } \\
\text { arnottianus }\end{array}$ & Aphis gossypii & Endangered & Negative & $\begin{array}{l}\text { Herbivory/grazing/ } \\
\text { browsing of mature plants }\end{array}$ & US, Hawaii & Observation & 63 & $\begin{array}{l}\text { Messing et al. } \\
(2007)\end{array}$ \\
\hline $\begin{array}{l}\text { Hibiscus } \\
\text { brackenridgei }\end{array}$ & Aphis gossypii & Endangered & Negative & $\begin{array}{l}\text { Herbivory/grazing/ } \\
\text { browsing of mature plants }\end{array}$ & US, Hawaii & Observation & 63 & $\begin{array}{l}\text { Messing et al. } \\
\text { (2007) }\end{array}$ \\
\hline $\begin{array}{l}\text { Himantopus } \\
\text { mexicanus } \\
\text { knudseni }\end{array}$ & Batis maritima & Endangered & Negative & $\begin{array}{l}\text { Competition monopolising } \\
\text { resources, shelter/habitat }\end{array}$ & US, Hawaii & $\begin{array}{l}\text { Observation } \\
\text { experimental }\end{array}$ & 73 & Morin (1998) \\
\hline $\begin{array}{l}\text { Himantopus } \\
\text { mexicanus } \\
\text { knudseni }\end{array}$ & Batis maritima & Endangered & Negative & $\begin{array}{l}\text { Ecosystem change or } \\
\text { habitat alteration, } \\
\text { modification of vegetation } \\
\text { type }\end{array}$ & US, Hawaii & Time-series & 72 & $\begin{array}{l}\text { Rauzon and } \\
\text { Drigot (2002) }\end{array}$ \\
\hline
\end{tabular}




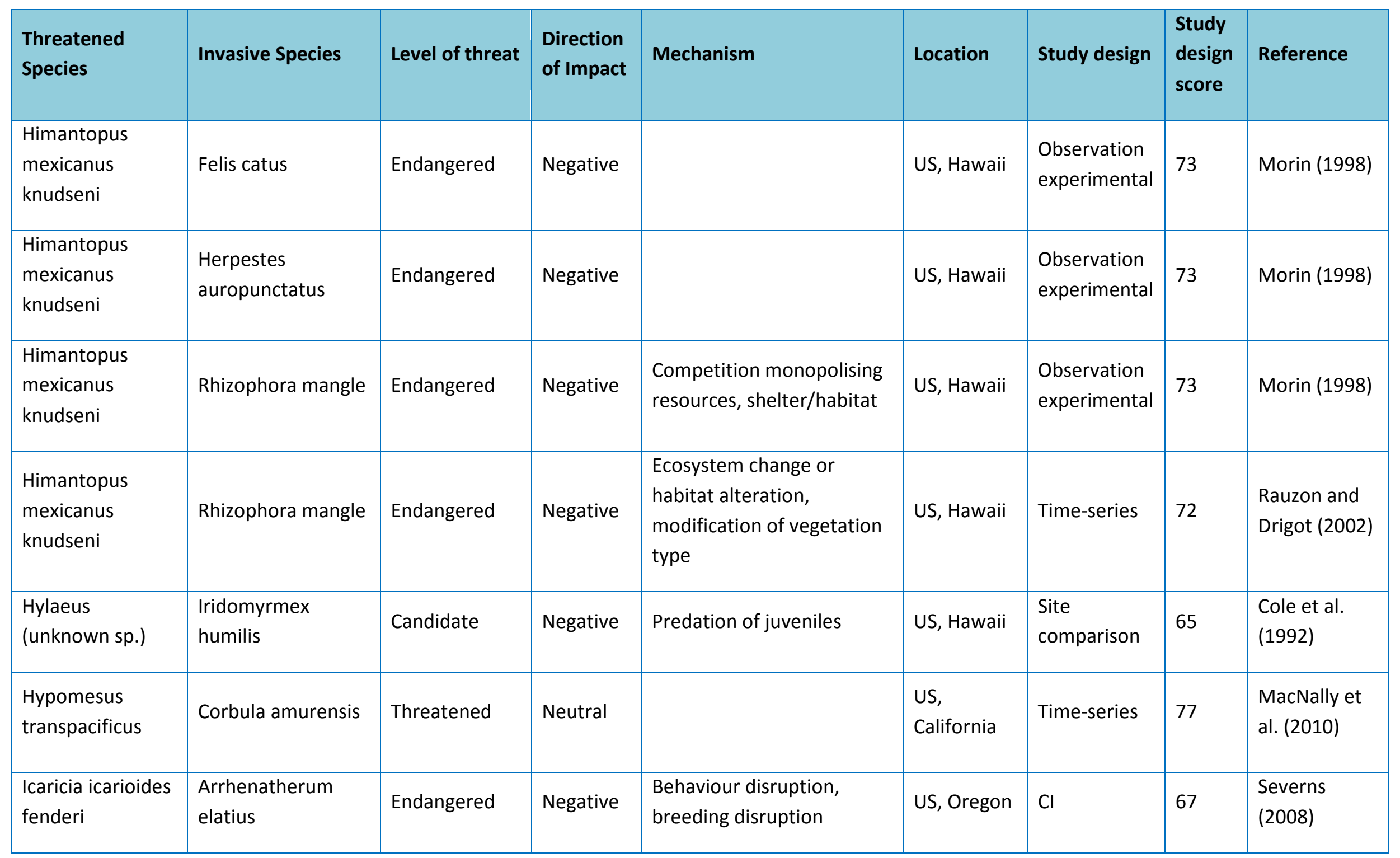




\begin{tabular}{|c|c|c|c|c|c|c|c|c|}
\hline $\begin{array}{l}\text { Threatened } \\
\text { Species }\end{array}$ & Invasive Species & Level of threat & $\begin{array}{l}\text { Direction } \\
\text { of Impact }\end{array}$ & Mechanism & Location & Study design & $\begin{array}{l}\text { Study } \\
\text { design } \\
\text { score }\end{array}$ & Reference \\
\hline $\begin{array}{l}\text { lotichthys } \\
\text { phlegethontis }\end{array}$ & Gambusia affinis & Candidate & Negative & $\begin{array}{l}\text { Competition monopolising } \\
\text { resources, shelter/habitat }\end{array}$ & US, Utah & $\begin{array}{l}\text { Interrupted } \\
\text { time-series }\end{array}$ & 61 & $\begin{array}{l}\text { Ayala et al. } \\
\text { (2007) }\end{array}$ \\
\hline $\begin{array}{l}\text { lotichthys } \\
\text { phlegethontis }\end{array}$ & Gambusia affinis & Candidate & Negative & Predation & US, Utah & $\mathrm{RCT}$ & 99 & $\begin{array}{l}\text { Mills et al. } \\
(2004)\end{array}$ \\
\hline $\begin{array}{l}\text { lotichthys } \\
\text { phlegethontis }\end{array}$ & Gambusia affinis & Candidate & Negative & Predation & $\begin{array}{l}\text { Lab } \\
\text { experiment }\end{array}$ & $\mathrm{RCT}$ & 97 & $\begin{array}{l}\text { Mills et al. } \\
(2004)\end{array}$ \\
\hline $\begin{array}{l}\text { lotichthys } \\
\text { phlegethontis }\end{array}$ & Gambusia affinis & Candidate & Negative & $\begin{array}{l}\text { Competition monopolising } \\
\text { resources, shelter/habitat }\end{array}$ & $\begin{array}{l}\text { Lab } \\
\text { experiment }\end{array}$ & $\mathrm{RCT}$ & 97 & $\begin{array}{l}\text { Mills et al. } \\
\text { (2004) }\end{array}$ \\
\hline $\begin{array}{l}\text { lotichthys } \\
\text { phlegethontis }\end{array}$ & Gambusia affinis & Candidate & Negative & Behaviour disruption & $\begin{array}{l}\text { Lab } \\
\text { experiment } \\
\text {, }\end{array}$ & $\begin{array}{l}\text { Observation } \\
\text { experimental }\end{array}$ & 77 & $\begin{array}{l}\text { Mills et al. } \\
(2004)\end{array}$ \\
\hline $\begin{array}{l}\text { Kokia } \\
\text { drynarioides }\end{array}$ & Aphis gossypii & Endangered & Negative & $\begin{array}{l}\text { Herbivory/grazing/ } \\
\text { browsing of mature plants }\end{array}$ & US, Hawaii & Observation & 63 & $\begin{array}{l}\text { Messing et al. } \\
(2007)\end{array}$ \\
\hline $\begin{array}{l}\text { Kokia } \\
\text { drynarioides }\end{array}$ & $\begin{array}{l}\text { Pennisetum } \\
\text { setaceum }\end{array}$ & Endangered & Negative & & US, Hawaii & RCT, ex-situ & 89 & $\begin{array}{l}\text { Cabin et al. } \\
(2002)\end{array}$ \\
\hline
\end{tabular}




\begin{tabular}{|c|c|c|c|c|c|c|c|c|}
\hline $\begin{array}{l}\text { Threatened } \\
\text { Species }\end{array}$ & Invasive Species & Level of threat & $\begin{array}{l}\text { Direction } \\
\text { of Impact }\end{array}$ & Mechanism & Location & Study design & $\begin{array}{l}\text { Study } \\
\text { design } \\
\text { score }\end{array}$ & Reference \\
\hline $\begin{array}{l}\text { Lanius } \\
\text { ludovicianus } \\
\text { mearnsi }\end{array}$ & Felis catus & Endangered & Negative & Predation of juveniles & $\begin{array}{l}\text { US, } \\
\text { California }\end{array}$ & Observation & 60 & $\begin{array}{l}\text { Scott and } \\
\text { Morrison } \\
(1990)\end{array}$ \\
\hline $\begin{array}{l}\text { Lanius } \\
\text { ludovicianus } \\
\text { mearnsi }\end{array}$ & Rattus rattus & Endangered & Negative & Predation of eggs & $\begin{array}{l}\text { US, } \\
\text { California }\end{array}$ & Time-series & 77 & $\begin{array}{l}\text { Heath et al. } \\
(2008)\end{array}$ \\
\hline $\begin{array}{l}\text { Loxops coccineus } \\
\text { coccineus }\end{array}$ & $\begin{array}{l}\text { Amblycera chewing } \\
\text { lice (unknown sp.) }\end{array}$ & Endangered & Negative & Parasitism & US, Hawaii & Time-series & 77 & $\begin{array}{l}\text { Freed et al. } \\
(2008)\end{array}$ \\
\hline $\begin{array}{l}\text { Loxops coccineus } \\
\text { coccineus }\end{array}$ & $\begin{array}{l}\text { Ischnocera chewing } \\
\text { lice (unknown sp.) }\end{array}$ & Endangered & Negative & Parasitism & US, Hawaii & Time-series & 77 & $\begin{array}{l}\text { Freed et al. } \\
\text { (2008) }\end{array}$ \\
\hline $\begin{array}{l}\text { Loxops coccineus } \\
\text { coccineus }\end{array}$ & $\begin{array}{l}\text { Zosterops } \\
\text { japonicus }\end{array}$ & Endangered & Negative & $\begin{array}{l}\text { Competition monopolising } \\
\text { resources, food/nutrients }\end{array}$ & US, Hawaii & Time-series & & $\begin{array}{l}\text { Freed and } \\
\text { Cann (2009) }\end{array}$ \\
\hline
\end{tabular}




\begin{tabular}{|c|c|c|c|c|c|c|c|c|}
\hline $\begin{array}{l}\text { Threatened } \\
\text { Species }\end{array}$ & Invasive Species & Level of threat & $\begin{array}{l}\text { Direction } \\
\text { of Impact }\end{array}$ & Mechanism & Location & Study design & $\begin{array}{l}\text { Study } \\
\text { design } \\
\text { score }\end{array}$ & Reference \\
\hline $\begin{array}{l}\text { Loxops coccineus } \\
\text { coccineus }\end{array}$ & $\begin{array}{l}\text { Zosterops } \\
\text { japonicus }\end{array}$ & Endangered & Negative & $\begin{array}{l}\text { Competition monopolising } \\
\text { resources, food/nutrients }\end{array}$ & US, Hawaii & Time-series & 73 & $\begin{array}{l}\text { Freed and } \\
\text { Cann (2012) }\end{array}$ \\
\hline $\begin{array}{l}\text { Malacothrix } \\
\text { indecora }\end{array}$ & Ovis aries & Endangered & Negative & $\begin{array}{l}\text { Herbivory/grazing/ } \\
\text { browsing of mature plants }\end{array}$ & $\begin{array}{l}\text { US, } \\
\text { California }\end{array}$ & $\begin{array}{l}\text { Interrupted } \\
\text { time-series }\end{array}$ & 67 & $\begin{array}{l}\text { Klinger et al. } \\
(2003)\end{array}$ \\
\hline $\begin{array}{l}\text { Malacothrix } \\
\text { squalida }\end{array}$ & Ovis aries & Endangered & Neutral & $\begin{array}{l}\text { Herbivory/grazing/ } \\
\text { browsing of mature plants }\end{array}$ & $\begin{array}{l}\text { US, } \\
\text { California }\end{array}$ & $\begin{array}{l}\text { Interrupted } \\
\text { time-series }\end{array}$ & 67 & $\begin{array}{l}\text { Klinger et al. } \\
(2003)\end{array}$ \\
\hline $\begin{array}{l}\text { Melamprosops } \\
\text { phaeosoma }\end{array}$ & Rattus exulans & Endangered & Negative & Predation & US, Hawaii & Observation & 60 & $\begin{array}{l}\text { Malcolm et } \\
\text { al. (2008) }\end{array}$ \\
\hline $\begin{array}{l}\text { Melamprosops } \\
\text { phaeosoma }\end{array}$ & Rattus rattus & Endangered & Negative & Predation & US, Hawaii & Observation & 60 & $\begin{array}{l}\text { Malcolm et } \\
\text { al. (2008) }\end{array}$ \\
\hline
\end{tabular}




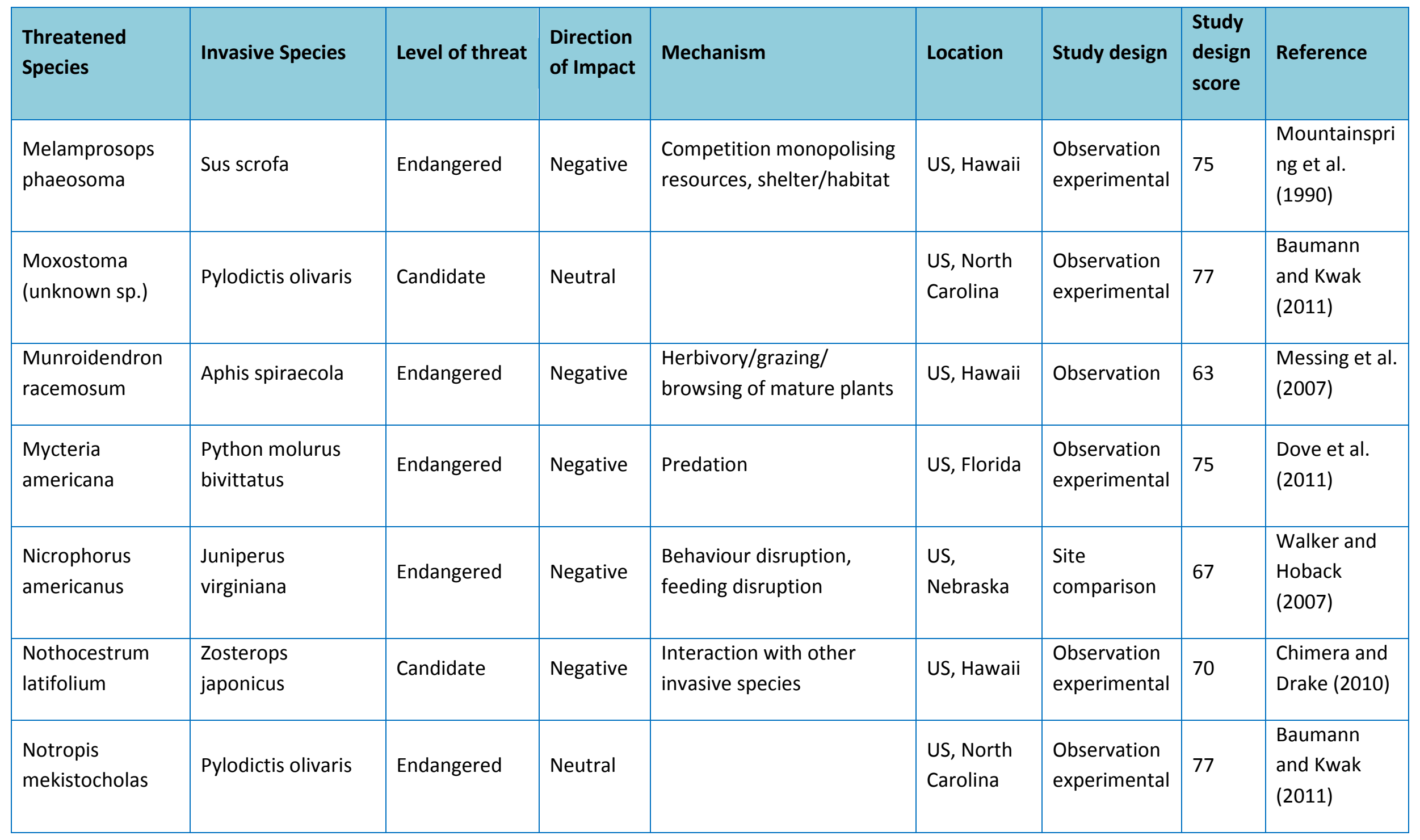




\begin{tabular}{|c|c|c|c|c|c|c|c|c|}
\hline $\begin{array}{l}\text { Threatened } \\
\text { Species }\end{array}$ & Invasive Species & Level of threat & $\begin{array}{l}\text { Direction } \\
\text { of Impact }\end{array}$ & Mechanism & Location & Study design & $\begin{array}{l}\text { Study } \\
\text { design } \\
\text { score }\end{array}$ & Reference \\
\hline $\begin{array}{l}\text { Oenothera } \\
\text { deltoides howellii }\end{array}$ & Bromus diandrus & Endangered & Negative & $\begin{array}{l}\text { Competition monopolising } \\
\text { resources, shelter/habitat }\end{array}$ & $\begin{array}{l}\text { US, } \\
\text { California }\end{array}$ & $\mathrm{Cl}$ & 67 & $\begin{array}{l}\text { Thomson } \\
\text { (2005b) }\end{array}$ \\
\hline $\begin{array}{l}\text { Oncorhynchus } \\
\text { mykiss }\end{array}$ & $\begin{array}{l}\text { Neogobius } \\
\text { melanostomus }\end{array}$ & Threatened & Neutral & $\begin{array}{l}\text { Competition monopolising } \\
\text { resources, food/nutrients }\end{array}$ & $\begin{array}{l}\text { US, } \\
\text { Michigan }\end{array}$ & $\begin{array}{l}\text { Site } \\
\text { comparison }\end{array}$ & 67 & $\begin{array}{l}\text { Kornis et al. } \\
\text { (2012) }\end{array}$ \\
\hline $\begin{array}{l}\text { Oncorhynchus } \\
\text { tshawytscha }\end{array}$ & Dreissena bugensis & Threatened & Negative & Altered food web & $\begin{array}{l}\text { US, } \\
\text { Michigan }\end{array}$ & $\begin{array}{l}\text { Interrupted } \\
\text { time-series }\end{array}$ & 63 & $\begin{array}{l}\text { Madenjian et } \\
\text { al. (2006) }\end{array}$ \\
\hline Oreomystis mana & $\begin{array}{l}\text { Zosterops } \\
\text { japonicus }\end{array}$ & Endangered & Negative & $\begin{array}{l}\text { Competition monopolising } \\
\text { resources, food/nutrients }\end{array}$ & US, Hawaii & Time-series & & $\begin{array}{l}\text { Freed and } \\
\text { Cann (2009) }\end{array}$ \\
\hline Oreomystis mana & $\begin{array}{l}\text { Zosterops } \\
\text { japonicus }\end{array}$ & Endangered & Negative & $\begin{array}{l}\text { Competition monopolising } \\
\text { resources, food/nutrients }\end{array}$ & US, Hawaii & Time-series & 73 & $\begin{array}{l}\text { Freed and } \\
\text { Cann (2012) }\end{array}$ \\
\hline $\begin{array}{l}\text { Oryzomys } \\
\text { palustris natator }\end{array}$ & Felis catus & Endangered & Negative & & $\begin{array}{l}\text { Ecuador, } \\
\text { Galapagos } \\
\text { Islands }\end{array}$ & $\begin{array}{l}\text { Site } \\
\text { comparison }\end{array}$ & 67 & $\begin{array}{l}\text { Dexter et al. } \\
(2004)\end{array}$ \\
\hline
\end{tabular}




\begin{tabular}{|c|c|c|c|c|c|c|c|c|}
\hline $\begin{array}{l}\text { Threatened } \\
\text { Species }\end{array}$ & Invasive Species & Level of threat & $\begin{array}{l}\text { Direction } \\
\text { of Impact }\end{array}$ & Mechanism & Location & Study design & $\begin{array}{l}\text { Study } \\
\text { design } \\
\text { score }\end{array}$ & Reference \\
\hline $\begin{array}{l}\text { Phoebastria } \\
\text { irrorata }\end{array}$ & Carpus hirca & Endangered & Negative & Unknown & $\begin{array}{l}\text { Ecuador, } \\
\text { Galapagos } \\
\text { Islands }\end{array}$ & Time-series & 71 & $\begin{array}{l}\text { Anderson et } \\
\text { al. (2002) }\end{array}$ \\
\hline Picoides borealis & Sturnus vulgaris & Endangered & Negative & & US, & Time-series & 75 & $\begin{array}{l}\text { Koenig } \\
(2003)\end{array}$ \\
\hline $\begin{array}{l}\text { Plagopterus } \\
\text { argentissimus }\end{array}$ & Cyprinella lutrensis & Threatened & Neutral & & US, Nevada & $\begin{array}{l}\text { Observation } \\
\text { experimental }\end{array}$ & 77 & $\begin{array}{l}\text { Holden and } \\
\text { Golden } \\
(2000)\end{array}$ \\
\hline $\begin{array}{l}\text { Plagopterus } \\
\text { argentissimus }\end{array}$ & Cyprinella lutrensis & Endangered & Negative & $\begin{array}{l}\text { Competition monopolising } \\
\text { resources, food/nutrients }\end{array}$ & US, Utah & $\begin{array}{l}\text { Interrupted } \\
\text { time-series }\end{array}$ & 62 & $\begin{array}{l}\text { Holden et al. } \\
\text { (2001) }\end{array}$ \\
\hline
\end{tabular}




\begin{tabular}{|c|c|c|c|c|c|c|c|c|}
\hline $\begin{array}{l}\text { Threatened } \\
\text { Species }\end{array}$ & Invasive Species & Level of threat & $\begin{array}{l}\text { Direction } \\
\text { of Impact }\end{array}$ & Mechanism & Location & Study design & $\begin{array}{l}\text { Study } \\
\text { design } \\
\text { score }\end{array}$ & Reference \\
\hline $\begin{array}{l}\text { Pseudognaphaliu } \\
\text { m } \\
\text { sandwicensium }\end{array}$ & Aphis gossypii & Candidate & Negative & $\begin{array}{l}\text { Herbivory/grazing/ } \\
\text { browsing of mature plants }\end{array}$ & US, Hawaii & Observation & 63 & $\begin{array}{l}\text { Messing et al. } \\
(2007)\end{array}$ \\
\hline $\begin{array}{l}\text { Pseudonestor } \\
\text { xanthophrys }\end{array}$ & Rat (unknown sp.) & Endangered & Negative & Predation & US, Hawaii & Observation & 55 & Knight (2001) \\
\hline $\begin{array}{l}\text { Pterodroma } \\
\text { phaeopygia }\end{array}$ & Canis familiaris & Endangered & Neutral & & $\begin{array}{l}\text { Ecuador, } \\
\text { Galapagos } \\
\text { Islands }\end{array}$ & Observation & 69 & $\begin{array}{l}\text { Cruz-Delgado } \\
\text { et al. (2010) }\end{array}$ \\
\hline $\begin{array}{l}\text { Pterodroma } \\
\text { phaeopygia }\end{array}$ & Owl (unknown sp.) & Endangered & Neutral & & $\begin{array}{l}\text { Ecuador, } \\
\text { Galapagos } \\
\text { Islands }\end{array}$ & Observation & 69 & $\begin{array}{l}\text { Cruz-Delgado } \\
\text { et al. (2010) }\end{array}$ \\
\hline
\end{tabular}




\begin{tabular}{|c|c|c|c|c|c|c|c|c|}
\hline $\begin{array}{l}\text { Threatened } \\
\text { Species }\end{array}$ & Invasive Species & Level of threat & $\begin{array}{l}\text { Direction } \\
\text { of Impact }\end{array}$ & Mechanism & Location & Study design & $\begin{array}{l}\text { Study } \\
\text { design } \\
\text { score }\end{array}$ & Reference \\
\hline $\begin{array}{l}\text { Pterodroma } \\
\text { phaeopygia }\end{array}$ & Rattus rattus & Endangered & Negative & Predation of juveniles & $\begin{array}{l}\text { Ecuador, } \\
\text { Galapagos } \\
\text { Islands }\end{array}$ & Observation & 69 & $\begin{array}{l}\text { Cruz-Delgado } \\
\text { et al. (2010) }\end{array}$ \\
\hline $\begin{array}{l}\text { Pterodroma } \\
\text { phaeopygia }\end{array}$ & Sus scrofa & Endangered & Neutral & & $\begin{array}{l}\text { Ecuador, } \\
\text { Galapagos } \\
\text { Islands }\end{array}$ & Observation & 69 & $\begin{array}{l}\text { Cruz-Delgado } \\
\text { et al. (2010) }\end{array}$ \\
\hline $\begin{array}{l}\text { Pterodroma } \\
\text { phaeopygia } \\
\text { sandwichensis }\end{array}$ & Felis catus & Endangered & Negative & Unknown & $\begin{array}{l}\text { Ecuador, } \\
\text { Galapagos } \\
\text { Islands }\end{array}$ & Observation & 55 & $\begin{array}{l}\text { Cruz and Cruz } \\
\text { (1987) }\end{array}$ \\
\hline $\begin{array}{l}\text { Pterodroma } \\
\text { phaeopygia } \\
\text { sandwichensis }\end{array}$ & Felis catus & Endangered & Negative & $\begin{array}{l}\text { Predation of mature } \\
\text { animals }\end{array}$ & US, Hawaii & $\begin{array}{l}\text { Observation } \\
\text { experimental }\end{array}$ & 75 & $\begin{array}{l}\text { Hess et al. } \\
(2008)\end{array}$ \\
\hline $\begin{array}{l}\text { Pterodroma } \\
\text { phaeopygia } \\
\text { sandwichensis }\end{array}$ & Rattus rattus & Endangered & Negative & Unknown & $\begin{array}{l}\text { Ecuador, } \\
\text { Galapagos } \\
\text { Islands }\end{array}$ & $\mathrm{BACl}$ & 75 & $\begin{array}{l}\text { Cruz and Cruz } \\
(1987)\end{array}$ \\
\hline $\begin{array}{l}\text { Pterodroma } \\
\text { phaeopygia } \\
\text { sandwichensis }\end{array}$ & Sus scrofa & Endangered & Negative & Predation of juveniles & $\begin{array}{l}\text { Ecuador, } \\
\text { Galapagos } \\
\text { Islands }\end{array}$ & Observation & 55 & $\begin{array}{l}\text { Cruz and Cruz } \\
\text { (1987) }\end{array}$ \\
\hline
\end{tabular}




\begin{tabular}{|c|c|c|c|c|c|c|c|c|}
\hline $\begin{array}{l}\text { Threatened } \\
\text { Species }\end{array}$ & Invasive Species & Level of threat & $\begin{array}{l}\text { Direction } \\
\text { of Impact }\end{array}$ & Mechanism & Location & Study design & $\begin{array}{l}\text { Study } \\
\text { design } \\
\text { score }\end{array}$ & Reference \\
\hline Rana draytonii & Rana catesbeiana & Threatened & Negative & $\begin{array}{l}\text { Behaviour disruption, } \\
\text { breeding disruption }\end{array}$ & $\begin{array}{l}\text { US, } \\
\text { California }\end{array}$ & Observation & 62 & $\begin{array}{l}\text { D'Amore et } \\
\text { al. (2009) }\end{array}$ \\
\hline Rana draytonii & Rana catesbeiana & Threatened & Negative & $\begin{array}{l}\text { Predation of mature } \\
\text { animals }\end{array}$ & $\begin{array}{l}\text { US, } \\
\text { California }\end{array}$ & Observation & 62 & $\begin{array}{l}\text { D'Amore et } \\
\text { al. (2009) }\end{array}$ \\
\hline Rana luteiventris & $\begin{array}{l}\text { salmonids } \\
\text { (unknown sp.) }\end{array}$ & Candidate & Neutral & & $\begin{array}{l}\text { US, Rock } \\
\text { Mountains }\end{array}$ & $\begin{array}{l}\text { Observation } \\
\text { experimental }\end{array}$ & 75 & $\begin{array}{l}\text { Pilliod et al. } \\
\text { (2010) }\end{array}$ \\
\hline Rana muscosa & $\begin{array}{l}\text { Trout (unknown } \\
\text { sp.) }\end{array}$ & Endangered & Negative & $\begin{array}{l}\text { Competition monopolising } \\
\text { resources, food/nutrients }\end{array}$ & $\begin{array}{l}\text { US, } \\
\text { California }\end{array}$ & $\begin{array}{l}\text { Observation } \\
\text { experimental }\end{array}$ & 79 & $\begin{array}{l}\text { Finlay and } \\
\text { Vredenburg } \\
(2007)\end{array}$ \\
\hline $\begin{array}{l}\text { Rhinichthys } \\
\text { osculus } \\
\text { nevadensis }\end{array}$ & $\begin{array}{l}\text { Tamarix } \\
\text { ramosissima }\end{array}$ & Endangered & Negative & Competition shading & US, Nevada & $\mathrm{BACl}$ & 75 & $\begin{array}{l}\text { Kennedy et } \\
\text { al. (2005) }\end{array}$ \\
\hline
\end{tabular}




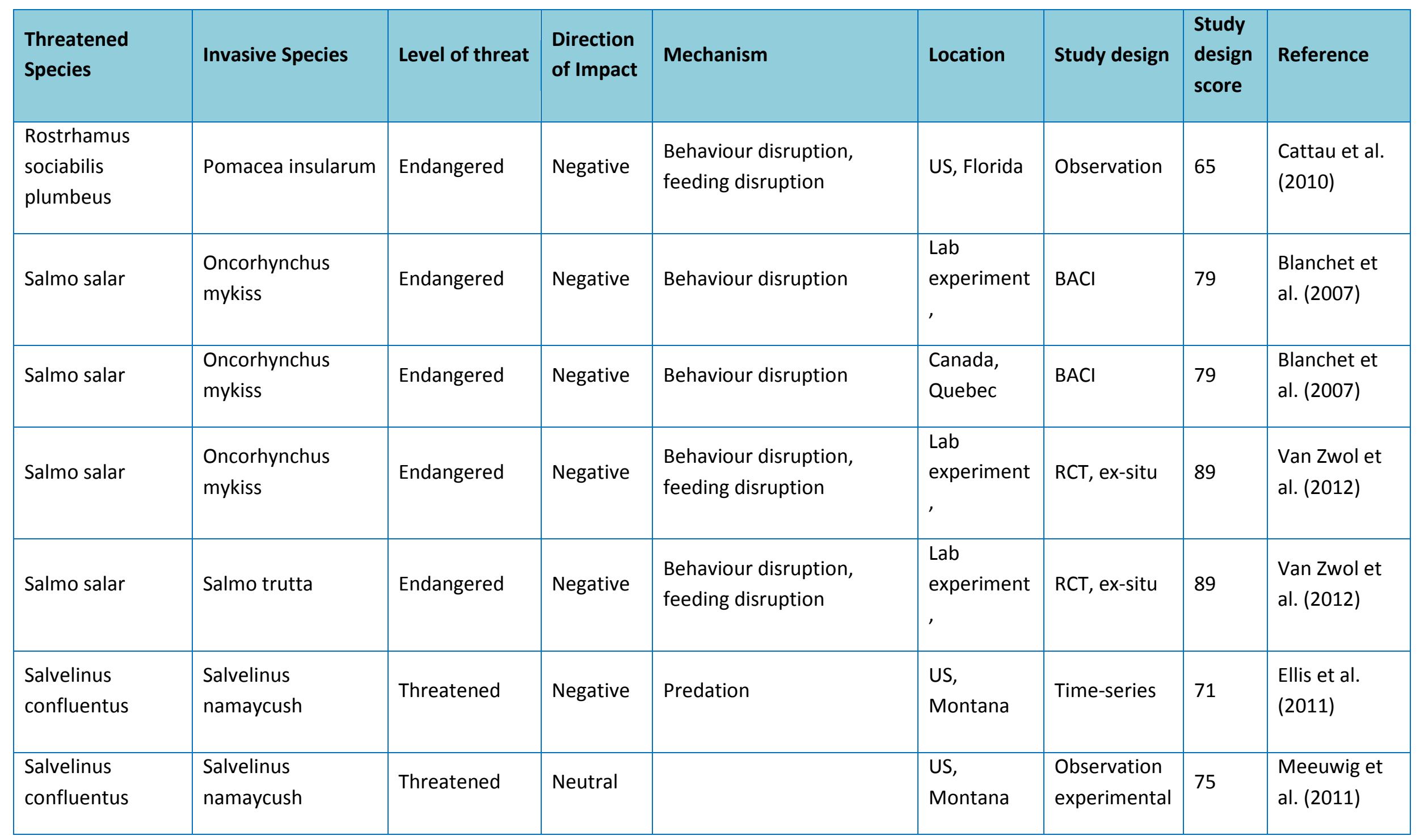




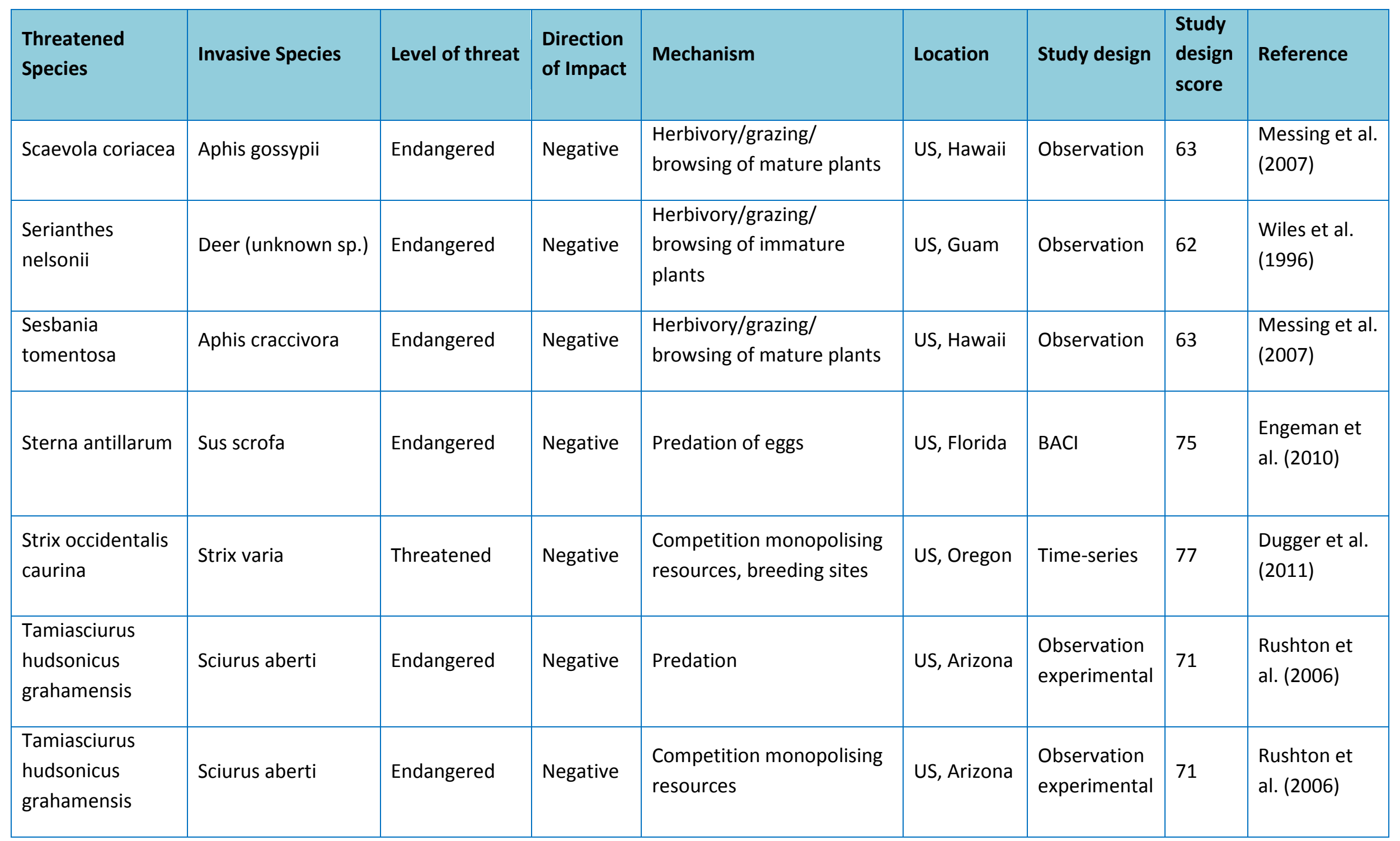




\begin{tabular}{|c|c|c|c|c|c|c|c|c|}
\hline $\begin{array}{l}\text { Threatened } \\
\text { Species }\end{array}$ & Invasive Species & Level of threat & $\begin{array}{l}\text { Direction } \\
\text { of Impact }\end{array}$ & Mechanism & Location & Study design & $\begin{array}{l}\text { Study } \\
\text { design } \\
\text { score }\end{array}$ & Reference \\
\hline $\begin{array}{l}\text { Tetramolopium } \\
\text { arenarium }\end{array}$ & Tagetes minuta L. & Endangered & Negative & Unknown & US, Hawaii & RCT, ex-situ & 89 & $\begin{array}{l}\text { Aplet and } \\
\text { Laven (1993) }\end{array}$ \\
\hline $\begin{array}{l}\text { Thysanocarpus } \\
\text { conchuliferus }\end{array}$ & Ovis aries & Endangered & Positive & $\begin{array}{l}\text { Herbivory/grazing/ } \\
\text { browsing of mature plants }\end{array}$ & $\begin{array}{l}\text { US, } \\
\text { California }\end{array}$ & $\begin{array}{l}\text { Interrupted } \\
\text { time-series }\end{array}$ & 67 & $\begin{array}{l}\text { Klinger et al. } \\
\text { (2003) }\end{array}$ \\
\hline Uma inornata & $\begin{array}{l}\text { Brassica } \\
\text { tournefortii }\end{array}$ & Threatened & Negative & Unknown & $\begin{array}{l}\text { US, } \\
\text { California }\end{array}$ & RCT & 99 & $\begin{array}{l}\text { Barrows et al. } \\
\text { (2009) }\end{array}$ \\
\hline Urocyon littoralis & Sus scrofa & Endangered & Negative & Predation of juveniles & $\begin{array}{l}\text { US, } \\
\text { California }\end{array}$ & $\begin{array}{l}\text { Observation } \\
\text { experimental }\end{array}$ & 75 & $\begin{array}{l}\text { Roemer et al. } \\
\text { (2001) }\end{array}$ \\
\hline
\end{tabular}




\begin{tabular}{|c|c|c|c|c|c|c|c|c|}
\hline $\begin{array}{l}\text { Threatened } \\
\text { Species }\end{array}$ & Invasive Species & Level of threat & $\begin{array}{l}\text { Direction } \\
\text { of Impact }\end{array}$ & Mechanism & Location & Study design & $\begin{array}{l}\text { Study } \\
\text { design } \\
\text { score }\end{array}$ & Reference \\
\hline $\begin{array}{l}\text { Urocyon littoralis } \\
\text { catalinae }\end{array}$ & $\begin{array}{l}\text { Canine distemper } \\
\text { virus }\end{array}$ & Endangered & Negative & Parasitism & $\begin{array}{l}\text { US, } \\
\text { California }\end{array}$ & $\begin{array}{l}\text { Observation } \\
\text { experimental }\end{array}$ & 70 & $\begin{array}{l}\text { Timm et al. } \\
\text { (2009) }\end{array}$ \\
\hline $\begin{array}{l}\text { Urocyon littoralis } \\
\text { littoralis }\end{array}$ & $\begin{array}{l}\text { Angiocaulus } \\
\text { gubernaculatus }\end{array}$ & Endangered & Negative & Parasitism & $\begin{array}{l}\text { US, } \\
\text { California }\end{array}$ & $\begin{array}{l}\text { Observation } \\
\text { experimental }\end{array}$ & 77 & $\begin{array}{l}\text { Coonan et al. } \\
(2005)\end{array}$ \\
\hline $\begin{array}{l}\text { Urocyon littoralis } \\
\text { littoralis }\end{array}$ & Aquila chrysaetos & Endangered & Negative & $\begin{array}{l}\text { Predation of mature } \\
\text { animals }\end{array}$ & $\begin{array}{l}\text { US, } \\
\text { California }\end{array}$ & $\begin{array}{l}\text { Observation } \\
\text { experimental }\end{array}$ & 77 & $\begin{array}{l}\text { Coonan et al. } \\
(2005)\end{array}$ \\
\hline Villosa fabalis & Dreissena bugensis & Endangered & Neutral & $\begin{array}{l}\text { Competition monopolising } \\
\text { resources, food/nutrients }\end{array}$ & $\begin{array}{l}\text { US, } \\
\text { Michigan }\end{array}$ & $\begin{array}{l}\text { Interrupted } \\
\text { time-series }\end{array}$ & & $\begin{array}{l}\text { Schloesser et } \\
\text { al. (1998) }\end{array}$ \\
\hline Villosa fabalis & $\begin{array}{l}\text { Dreissena } \\
\text { polymorpha }\end{array}$ & Endangered & Neutral & $\begin{array}{l}\text { Competition monopolising } \\
\text { resources, food/nutrients }\end{array}$ & $\begin{array}{l}\text { US, } \\
\text { Michigan }\end{array}$ & $\begin{array}{l}\text { Interrupted } \\
\text { time-series }\end{array}$ & 58 & $\begin{array}{l}\text { Schloesser et } \\
\text { al. (1998) }\end{array}$ \\
\hline
\end{tabular}




\begin{tabular}{|c|c|c|c|c|c|c|c|c|}
\hline $\begin{array}{l}\text { Threatened } \\
\text { Species }\end{array}$ & Invasive Species & Level of threat & $\begin{array}{l}\text { Direction } \\
\text { of Impact }\end{array}$ & Mechanism & Location & Study design & $\begin{array}{l}\text { Study } \\
\text { design } \\
\text { score }\end{array}$ & Reference \\
\hline
\end{tabular}




\section{Appendix Five: Still visuals of the taxonomic species pair data}

The following figures show various flat images from an interactive data visualisation which is being compissioned for the review. The final interactive visual aims to show the data and evidence numbers together. In the flat visuals we use the following key to assist in the representation of the data.

The weight of the line is representative of the number of cases - therefore you could have for instance from an invasive fish 10 cases of "predation" occurring however after exiting the impact category they split to impact two listed amphibian species and eight listed fish species.

The colour of the line represents the outcome of the impact :

- $\quad$ red $=$ negative to the listed species

- $\quad$ blue = neutral to both species

- green = a positive outcome for the listed species in light of the invasive being presented

Insect
Mammal
Mollusc
Plant
Protozoa
Reptile
Worus




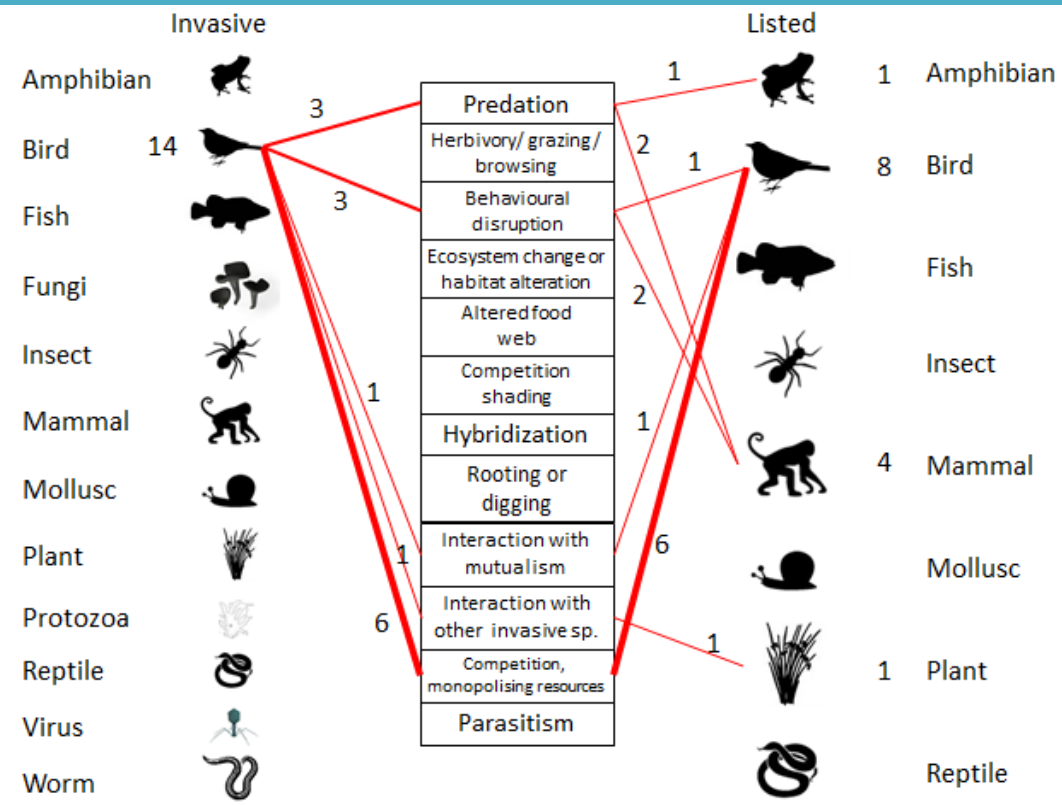

The 14 cases of impact that invasive birds have on listed amphibian, bird, mammal and plant species. The two neutral unknown cases of impacts to listed birds are not mapped.

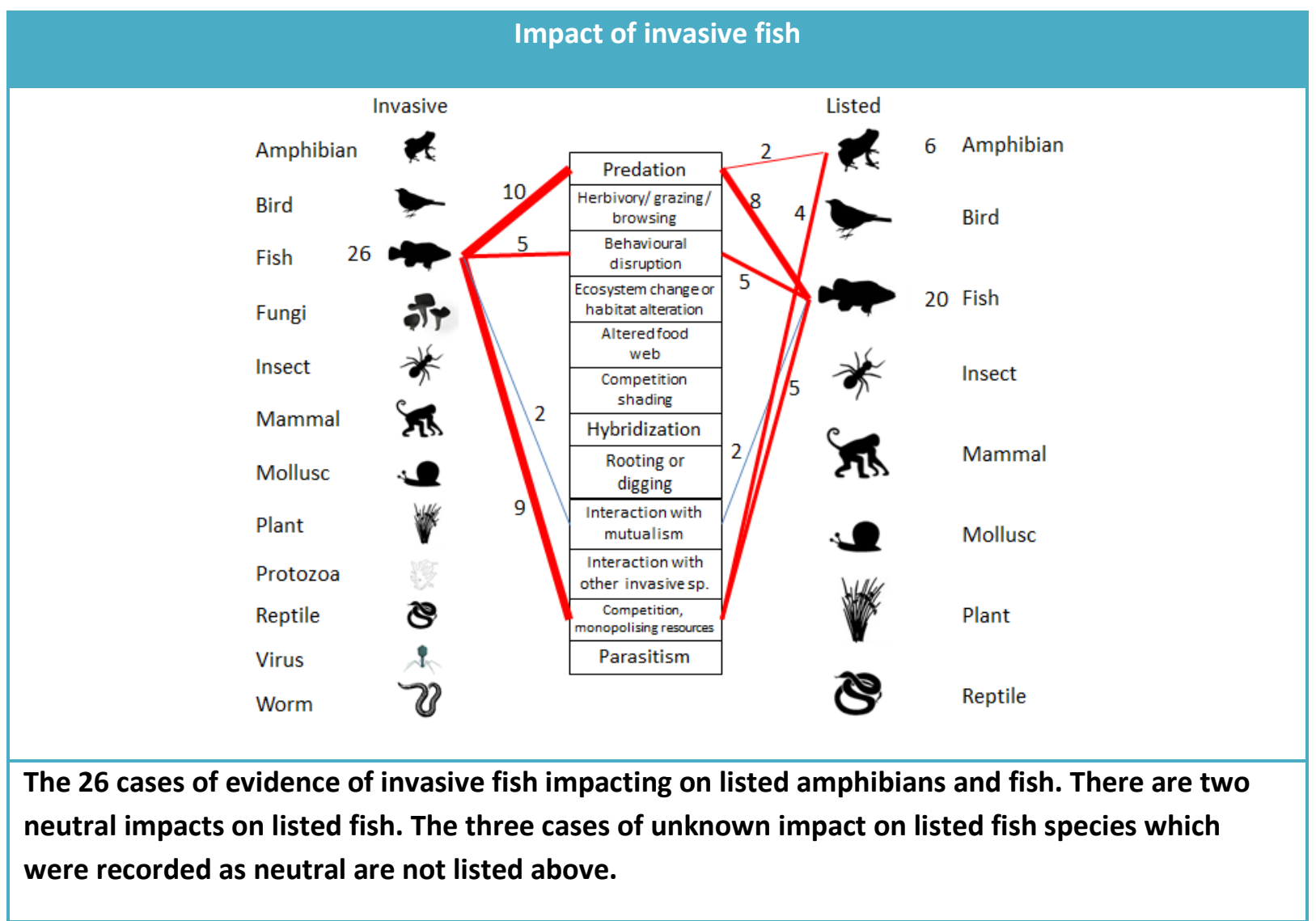


Impact of invasive fungi, protozoa, reptile, virus and worm species

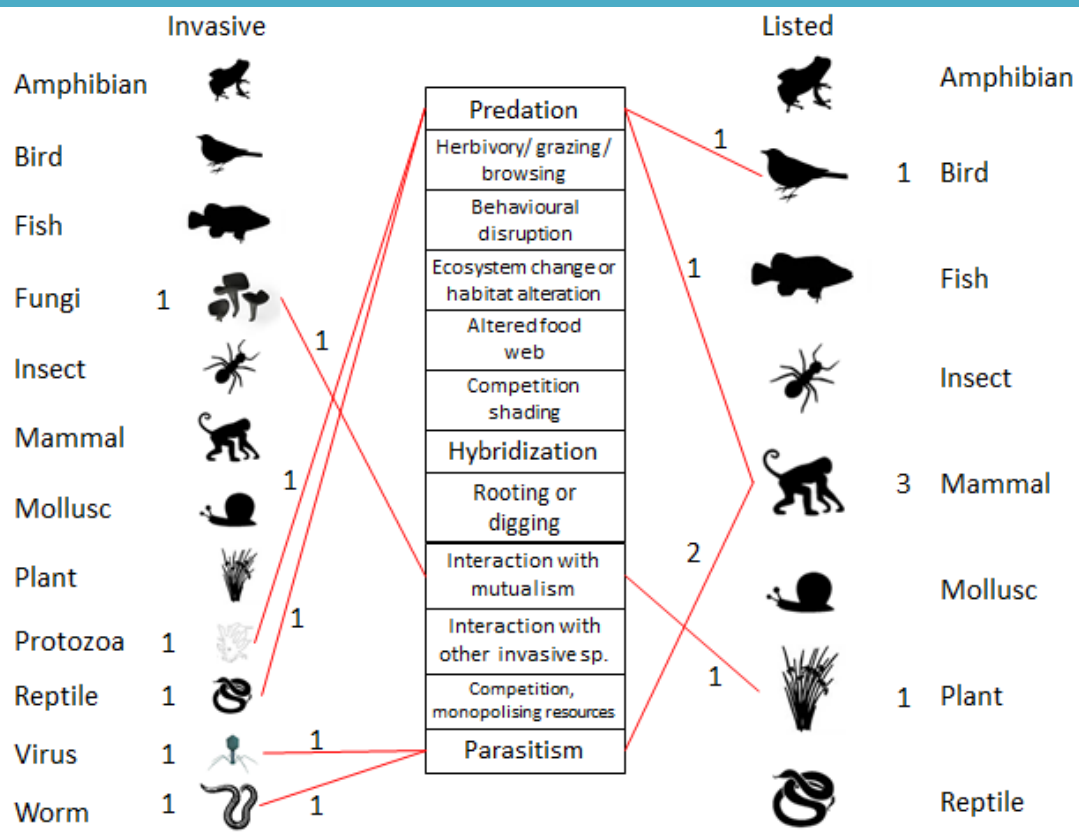

The evidence for invasive fungi, protozoa, reptile, virus and worm species impacting on listed birds, mammals and plant species.

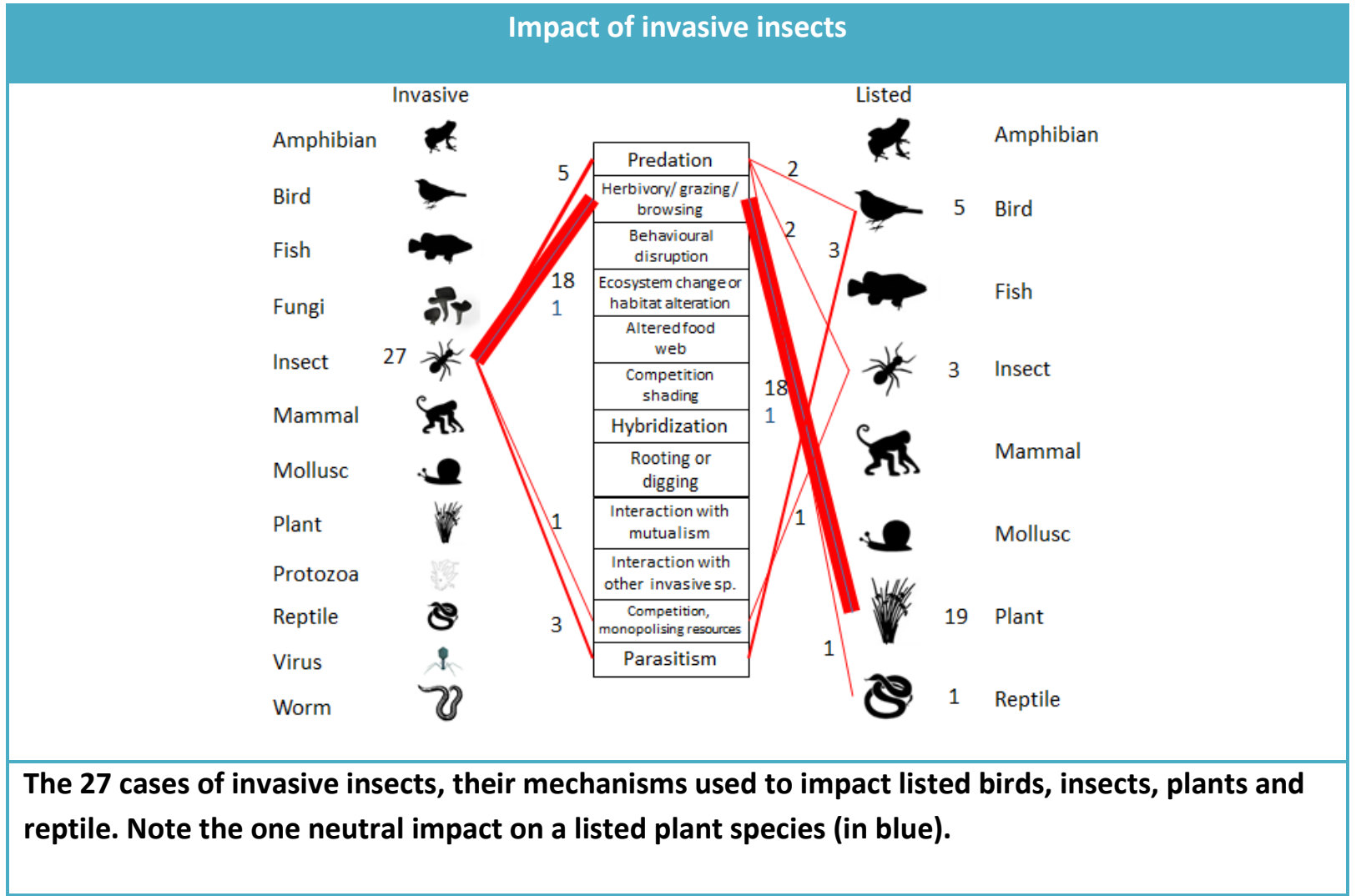




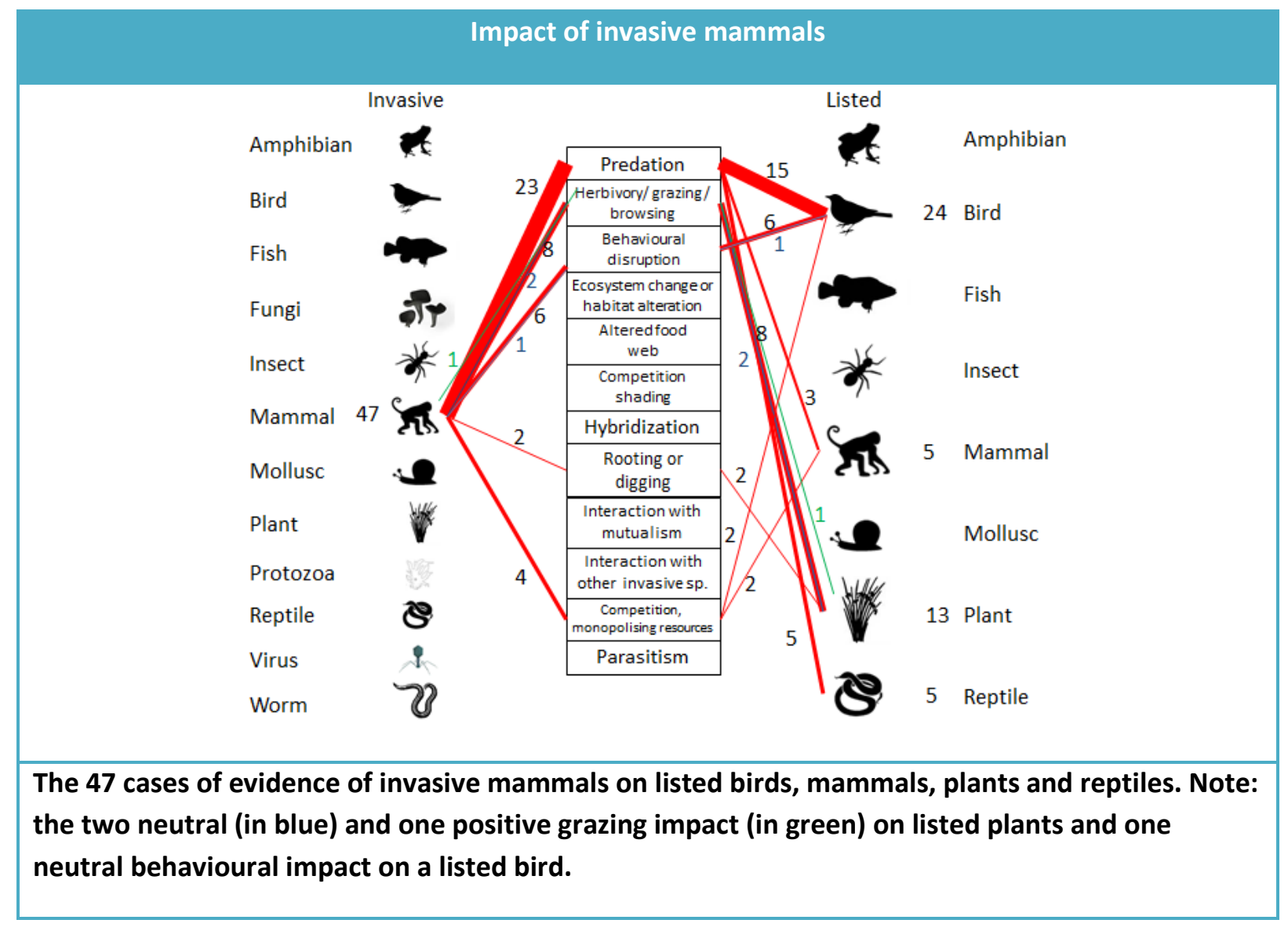

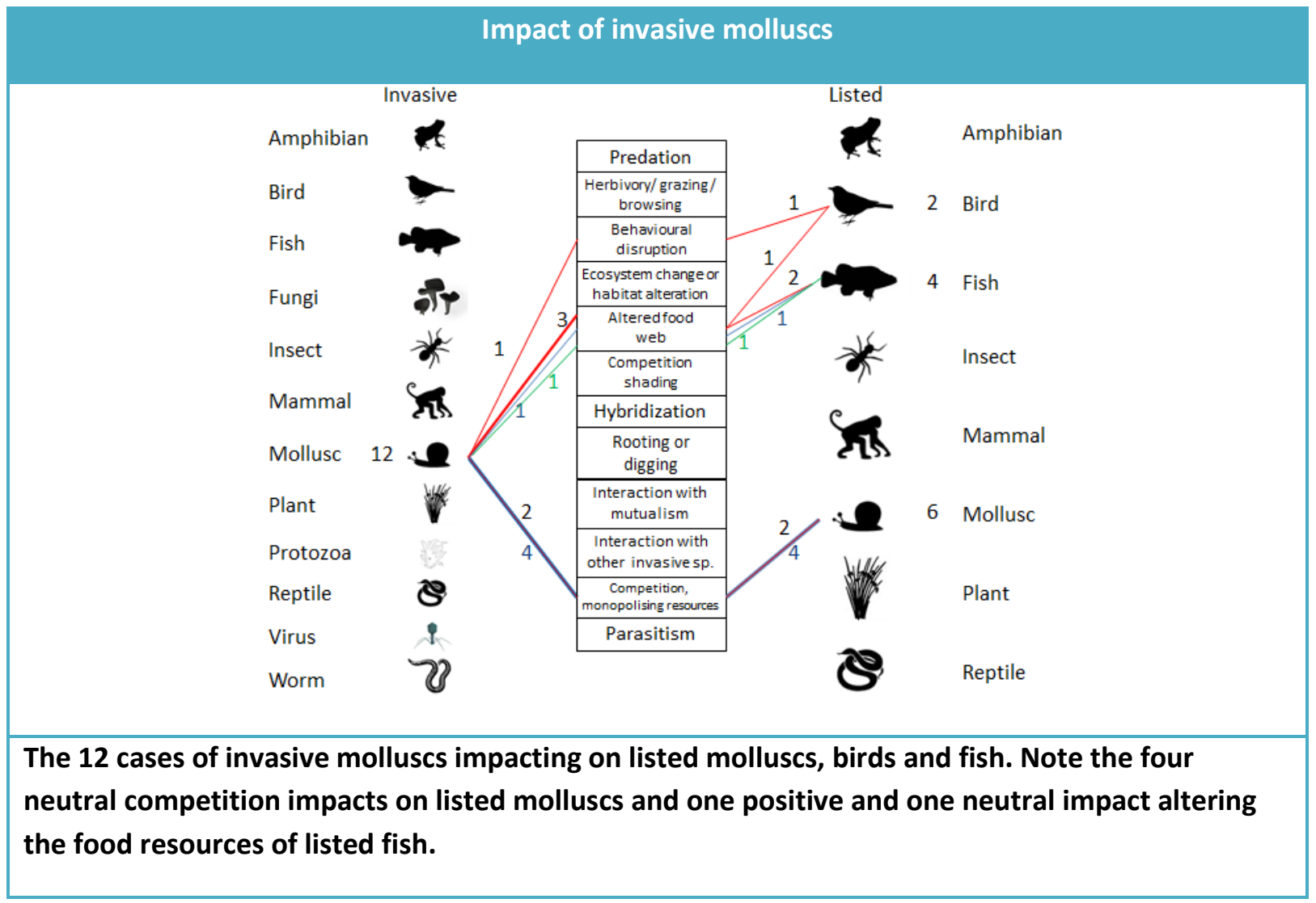




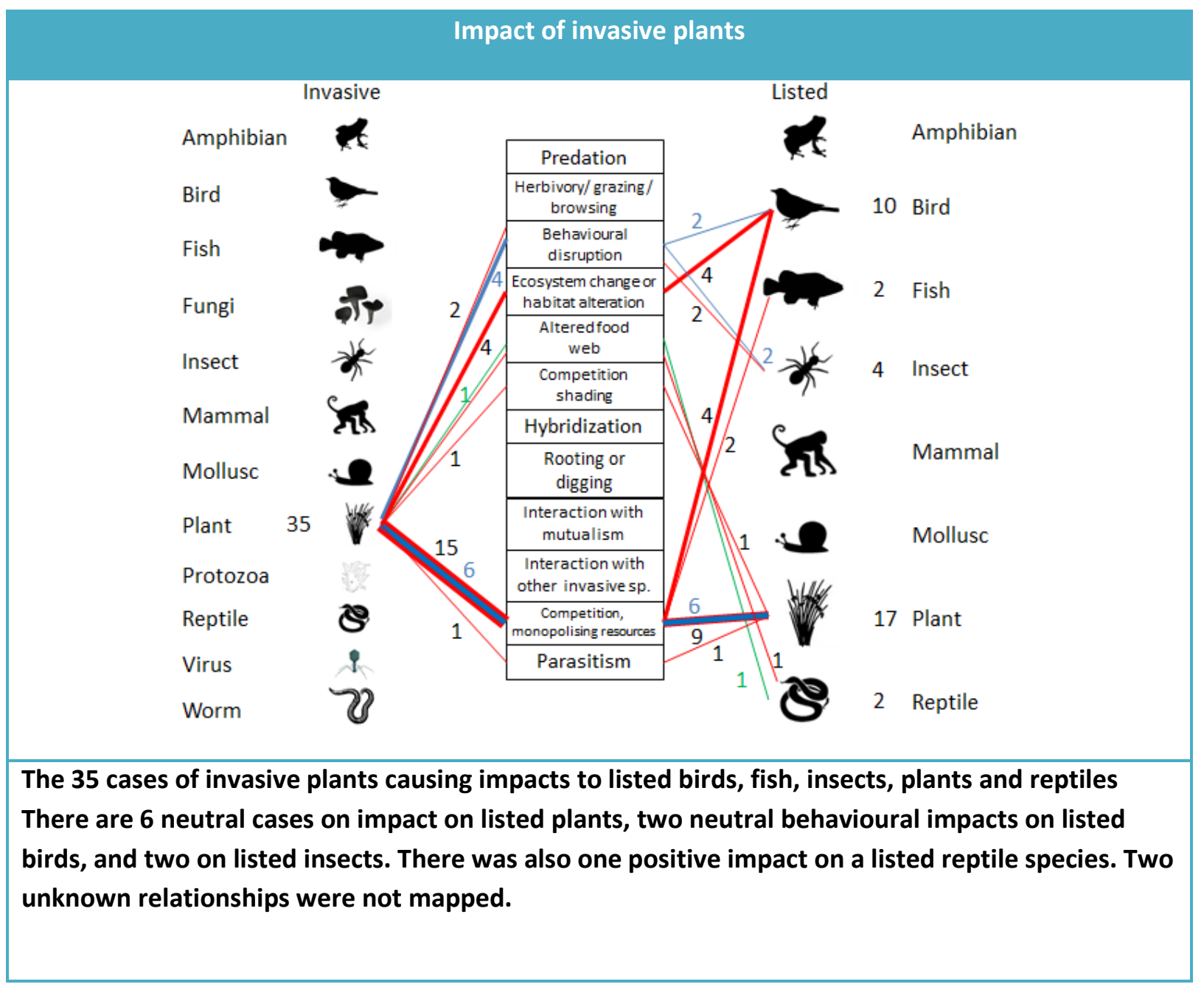

\section{Appendix Six: List of references included in the final review from which data was extracted from.}

Anderson DJ, Huyvaert KP, Apanius V, et al. (2002) Population size and trends of the waved albatross Phoebastria irrorata. Marine Ornithology 30:63-69

Aplet GH, Laven RD (1993) Relative performance of four Hawaiian shrubby plants (Asteraceae) under greenhouse conditions with implications for rarity. Biological Conservation 65:15-21

Ayala J, Rader R, Belk M, et al. (2007) Ground-truthing the impact of invasive species: spatio-temporal overlap between native least chub and introduced western mosquitofish. Biological Invasions 9:857-869

Baiser B, Lockwood JL, Puma DI, et al. (2008) A perfect storm: two ecosystem engineers interact to degrade deciduous forests of New Jersey. Biological Invasions 10:785-795 
Barrows C, Allen E, Brooks M, et al. (2009) Effects of an invasive plant on a desert sand dune landscape. Biological Invasions 11:673-686

Baskett CA, Emery SM, Rudgers JA (2011) Pollinator visits to threatened species are restored following invasive plant removal. International Journal of Plant Sciences 172:411-422

Baumann JR, Kwak TJ (2011) Trophic relations of introduced flathead catfish in an Atlantic river. Transactions of the American Fisheries Society 140:1120-1134

Blanchet, S, Loot G, Bernatchez, L, Dodson JJ (2007) The disruption of dominance hierarchies by a non-native species: an individual-based analysis. Oecologia 152:569581 DOI 10.1007/s00442-007-0668-4

Cabin, RJ, Weller SG, Lorence, DH, Cordell, S. Hadway LJ, Montgomery R, Don Goo, D, Urakami, A (2002) Effects of light, alien grass, and native species additions on hawaiian dry forest restoration. Ecological Applications 12(6): 1595-1610.

Cabin RJ, Weller, SG, Lorence DH Cordell S, Hadway LH (2002) Effects of microsite, water, weeding, and direct seeding on the regeneration of native and alien species within a Hawaiian dry forest preserve. Biological Conservation 104: 181-190

Campomizzi AJ, Morrison ML, Farrell SL, et al. (2009) Red imported fire ants can decrease songbird nest survival. Condor 111:534-537

Carlsen TM, Menke JW, Pavlik BM (2000) Reducing competitive suppression of a rare annual forb by restoring native California perennial grasslands. Restoration Ecology 8:18-29.

Cattau CE, Martin J, Kitchens WM (2010) Effects of an exotic prey species on a native specialist: example of the snail kite. Biological Conservation 143:513-520

Caut S, Angulo E, Courchamp F (2008) Dietary shift of an invasive predator: rats, seabirds and sea turtles. Journal of Applied Ecology 45:428-437

Chatto R (2004) Improving survivorship of the nests of the endangered Olive Ridley sea turtles - the reductions of feral dog numbers from northern beaches on Melville Island, Tiwi Islands, NT. Report to the Department of Environment and Heritage and WWF Australia. Australian Government, Department of the Environment and Heritage, pp. 1-19

Chimera CG, Drake, DR (2010) Patterns of seed dispersal and dispersal failure in a Hawaiian dry forest having only introduced birds. Biotropica 42: 493-502 10.1111/j.1744-7429.2009.00610.x

Cole FR, Medeiros AC, Loope, LL, Zuehlke WW (1992) Effects of the Argentine ant on arthropod fauna of Hawaiian high-elevation shrubland. Ecology 73:1313-1322

Collins PW, Latta BC, Roemer GW (2009) Does the order of invasive species removal matter? The case of the eagle and the pig. PLoS One:e7005

Coonan TJ, Schwemm CA, Roemer GW, et al. (2005) Decline of an island fox subspecies to near extinction. Southwestern Naturalist 50:32-41

Cruz JB, Cruz F (1987) Conservation of the dark-rumped petrel Pterodroma phaeopygia in the Galapagos Islands, Ecuador. Biological Conservation 42:303-311 
Cruz-Delgado F, González JA, Wiedenfeld DA (2010) Breeding biology of the critically endangered Galapagos petrel Pterodroma phaeopygia on San Cristóbal Island: conservation and management implications. Bird Conservation International 20:306-319.

D'Amore A, Kirby E, McNicholas, M (2009) Invasive species shifts ontogenetic resource partitioning and microhabitat use of a threatened native amphibian. Aquatic Conservation: Marine and Freshwater Ecosystems 19: 534-541

D'Amore A, Kirby E, Hemingway V (2009) Reproductive interference by an invasive species: an evolutionary trap? Herpetological Conservation and Biology 4:325-330

Dexter N, Dowler RC, Flanagan JP, Hart, S, Revelez, MA, Lee, TE (2004) The influence of feral cats Felis catus on the distribution and abundance of introduced and endemic Galapagos rodents. Pacific Conservation Biology 10:210-215

Diffie S, Miller J, Murray K (2010) Laboratory observations of red imported fire ant (Hymenoptera: Formicidae) predation on reptilian and avian eggs. Journal of Herpetology 44:294-296

Dove CJ, Snow RW, Rochford MR, Mazzotti FJ (2011) Birds consumed by the invasive Burmese python (Python molurus bivittatus) in Everglades National Park, Florida, USA. The Wilson Journal of Ornithology 123:126-131

Dugger KM, Anthony, R.G., and Andrews, L.S. (2011) Transient dynamics of invasive competition: barred owls, spotted owls, habitat, and the demons of competition present. Ecological Applications 21:2459-2468

Ellis BK, Stanford JA, Goodman D, et al. (2011) Long-term effects of a trophic cascade in a large lake ecosystem. Proceedings of the National Academy of Sciences of the United States of America 108:1070-1075

Engeman R, Whisson D, Quinn J, et al. (2006) Monitoring invasive mammalian predator populations sharing habitat with the critically endangered Puerto Rican parrot Amazona vittata. Oryx 40:95-102

Engeman RM, Duffiney A, Braem S, et al. (2010) Dramatic and immediate improvements in insular nesting success for threatened sea turtles and shorebirds following predator management. Journal of Experimental Marine Biology and Ecology 395:147-152

Erwin TL, Young TP (2010) A native besieged: Effects of normative frugivores and ground vegetation on seed removal in a highly endangered Hawaiian shrub, Delissea rhytidosperma (Campanulaceae). Pacific Science 64:33-43

Fellows MQN, Zedler JB (2005) Effects of the non-native grass, Parapholis incurva (Poaceae), on the rare and endangered hemiparasite, Cordylanthus maritimus subsp. Maritimus (Scrophulariaceae). Madroño 52:91-98

Finlay JC, Vredenburg VT (2007) Introduced trout sever trophic connections in watersheds: consequences for a declining amphibian. Ecology 88:2187-2198

Fitzpatrick BM, Johnson JR, Kump DK, et al. (2010) Rapid spread of invasive genes into a threatened native species. Proceedings of the National Academy of Sciences of the United States of America 107:3606-3610

Fitzpatrick BM, Shaffer HB (2007) Hybrid vigor between native and introduced 
salamanders raises new challenges for conservation. Proceedings of the National Academy of Sciences of the United States of America 104:15793-15798

Flint E, Rehkemper C (2003) Control and eradication of the introduced grass, Cenchrus echinatus, at Laysan Island, Central Pacific Ocean. Occasional Paper of the IUCN Species Survival Commission No.27. IUCN-The World Conservation Union, Gland, pp. 110-115

Frank PA, Humphrey SR (1996) Populations, habitat requirements, and management of the endemic Anastasia Island beach mouse (Peromyscus polionotus phasma), emphasizing the potential threat of exotic house mice (Mus musculus). Submitted as Final Report for Florida Game and Fresh Water Fish Commission Project NG88-006.

Freed LA, Cann RL (2009) Negative effects of an introduced bird species on growth and survival in a native bird community. Current Biology 19:1736-1740

Freed LA, Cann RL (2012) Increase of an introduced bird competitor in old-growth forest associated with restoration. NeoBiota 13: 43-60.

Freed LA, Cann RL, Bodner GR (2008) Incipient extinction of a major population of the Hawaii akepa owing to introduced species. Evolutionary Ecology Research 10:931-965

Heath SR, Kershner EL, Cooper DM, et al. (2008) Rodent control and food supplementation increase productivity of endangered San Clemente loggerhead shrikes (Lanius Iudovicianus mearnsi). Biological Conservation 141:2506-2515

Hellmair M, Goldsmith G, Kinziger A (2011) Preying on invasives: the exotic New Zealand mudsnail in the diet of the endangered tidewater goby. Biological Invasions 13:2197-2201

Hess SC, Banko PC, Goltz DM, Danner RM, Brinck KW (2004) Strategies for reducing feral cat threats to endangered Hawaiian birds. Proceedings of the Vertebrate Pest Conference 21:21-26.

Hess, SC, Hansen, H, Banko, PC (2008) Reducing feral cat threats to native wildlife in Hawai i Technical Report HCSU-010. Hawai'i Cooperative Studies Unit, University of Hawai'i at Hilo, Hawai'i.

Holden PB, Golden ME (2000) Lower Virgin River endangered fish studies, 1998-2000. Evaluation of mechanical removal of red shiner (Cyprinella lutrensis), survival of stocked woundfin (Plagopterus argentissimus), and results of monitoring. Report PR-723-01 Prepared for Bureau of Reclamation, Lower Colorado Regional Office and Southern Nevada Water Authority.

Holden, PB, Golden ME and Zucker SJ (2001) An evaluation of changes in woundfin (Plagopterus argentissimus) populations in the Virgin River, Utah, Arizona, and Nevada, 1976-1999. Report \#PR-735-1 by BIO-WEST, Inc., Logan, Utah. 77pp.

Huenneke LF, Thomson JK (1995) Potential interference between a threatened endemic thistle and an invasive nonnative plant. Conservation Biology 9:416-425

Huxel GR (2000) The effect of the Argentine ant on the threatened valley elderberry longhorn beetle. Biological Invasions 2:81-85

Joe S, Daehler C (2008) Invasive slugs as under-appreciated obstacles to rare plant 
restoration: evidence from the Hawaiian Islands. Biological Invasions 10:245-255

Kennedy TA, Finlay JC, Hobbie SE (2005) Eradication of invasive Tamarix ramosissima along a desert stream increases native fish density. Ecological Applications 15:20722083

Klaus, N, Keyes, T (2007) Effect of two native invasive tree species on upland pine breeding bird communities in Georgia. The Wilson Journal of Ornithology, 119:737-741 DOI: http://dx.doi.org/10.1676/06-125.1

Klinger RC, Schuyler P, and Sterner JD (2002) The response of herbaceous vegetation and endemic plant species to the removal of feral sheep from Santa Cruz Island, California. In Turning the Tide: The Eradication of Invasive Species Proceedings of the International Conference On Eradication of Island Invasives. Edited by CR Veitch and MN Clout, Occasional Paper of the IUCN Species Survival Commission No. 27. pp. 141-154

Knight D (2001) From birds in the hand to birds in the bush. California Wild 53 (2)

Koenig WD (2003) European starlings and their effect on native cavity-nesting birds. Conservation Biology 17: 1134-1140

Kornis MS, Sharma S, Vander Zanden, MJ (2012) Invasion success and impact of an invasive fish, round goby, in Great Lakes Tributaries. Diversity and Distributions 19:184-198

Lafferty K, Page C (1997) Predation on the endangered tidewater goby, Eucyclogobius newberryi, by the introduced African clawed frog, Xenopus laevis, with notes on the frog's parasites. Copeia 3:589-592

Leighton PA, Horrocks JA, Kramer DL (2010) Conservation and the scarecrow effect: Can human activity benefit threatened species by displacing predators? Biological Conservation 143:2156-2163

Lewis PA, DeLoach CJ, Herr JC, Dudley TL, Carruthers RI (2003) Assessment of risk to native Frankenia shrubs from an Asian leaf beetle, Diorhabda elongata deserticola (Coleoptera: Chrysomelidae), introduced for biological control of saltcedars (Tamarix spp.) in the western United States. Biological Control 27:148-166

Louda SM, Rand TA, Arnett AE, et al. (2005) Evaluation of ecological risk to populations of a threatened plant from an invasive biocontrol insect. Ecological Applications 15:234249

MacNally R, Thomson JR, Kimmerer WJ, et al. (2010) Analysis of pelagic species decline in the upper San Francisco Estuary using multivariate autoregressive modeling (MAR). Ecological Applications 20:1417-1430

Madenjian CP, Pothoven SA, Dettmers JM, et al. (2006) Changes in seasonal energy dynamics of alewife (Alosa pseudoharengus) in Lake Michigan after invasion of dreissenid mussels. Canadian journal of fisheries and aquatic sciences 63:891-902

Malcolm TR, Swinnerton KJ, Groombridge JJ, et al. (2008) Ground-based rodent control in a remote Hawaiian rainforest on Maui. Pacific Conservation Biology 14:206-214

Maret TJ, Snyder JD, Collins JP (2006) Altered drying regime controls distribution of 
endangered salamanders and introduced predators. Biological Conservation 127:129138

Marsh PC, Douglas ME (1997) Predation by introduced fishes on endangered humpback chub and other native species in the Little Colorado River, Arizona. Transactions of the American Fisheries Society 126:343-346

McEachern AK, Thomson DM, Chess KA (2009) Climate alters response of an endemic island plant to removal of invasive herbivores. Ecological Applications 19:1574-1584

McKinney ST, Fiedler CE, Tomback DF (2009) Invasive pathogen threatens bird-pine mutualism: implications for sustaining a high-elevation ecosystem. Ecological Applications 19:597-607

Meeuwig MH, Guy CS, Fredenberg WA (2011) Trophic relationships between a native and a nonnative predator in a system of natural lakes. Ecology of Freshwater Fish 20:315-325

Meffe GK, Hendrickson DA, Minckley WL, et al. (1983) Factors resulting in decline of the endangered Sonoran topminnow Poeciliopsis occidentalis (Atheriniformes: Poeciliidae) in the United States. Biological Conservation 25:135-159

Messing RH, Tremblay, MN, Mondor, EB, Foottit, RG, Pike, KS. (2007) Invasive aphids attack native Hawaiian plants Biological Invasions (2007) 9:601-607. DOI 10.1007/s10530-006-9045-1

Miller MA, Gardner IA, Kreuder C, et al. (2002) Coastal freshwater runoff is a risk factor for Toxoplasma gondii infection of southern sea otters (Enhydra lutris nereis). International Journal for Parasitology 32:997-1006

Mills MD, Rader RB, Belk MC (2004) Complex interactions between native and invasive fish: the simultaneous effects of multiple negative interactions. Oecologia 141:713-721

Morin MP (1998) Endangered waterbird and wetland status, Kaloko- Honokohau National Historical Park, Hawai i Island. Cooperative National Park Resources Studies Unit, Hawai'i Technical Report 119:62

Mountainspring S, Casey TL, Kepler CB, et al. (1990) Ecology, behavior, and conservation of the poo-uli (Melamprosops phaeosoma). Wilson Bulletin 102:109-122

Munk LM, Hild AL, Whitson TD (2002) Rosette recruitment of a rare endemic forb (Gaura neomexicana subsp. coloradensis) with canopy removal of associated species.

Restoration Ecology 10:122-128

Pilliod DS, Hossack BR, Bahls PF, et al. (2010) Non-native salmonids affect amphibian occupancy at multiple spatial scales. Diversity and Distributions 16:959-974

Rauzon MJ (1999) Tropical island seabirds: some conservation considerations. Birding $31: 422-433$

Rauzon MJ, Drigot, DC (2002) Red mangrove eradication and pickleweed control in a Hawaiian wetland, waterbird responses, and lessons learned. In Turning the tide: the eradication of invasive species. CR. Veitch and MN. Clout (eds.) IUCN SSC Invasive Species Specialist Group. IUCN, Switzerland and Cambridge, UK. pp. 240-248. 
Roemer GW, Coonan TJ, Garcelon DK, et al. (2001) Feral pigs facilitate hyperpredation by golden eagles and indirectly cause the decline of the island fox. Animal Conservation 4:307-318

Rushton SP, Wood DJA, Lurz PWW, et al. (2006) Modelling the population dynamics of the Mt. Graham red squirrel: Can we predict its future in a changing environment with multiple threats? Biological Conservation 131:121-131

Russell DJ, Balazs GH (1994) Colonization by the alien marine alga Hypnea musciformis (Wulfen) J. Ag. (Rhodophyta: Gigartinales) in the Hawaiian islands and its utilization by the green turtle, Chelonia mydas L. Aquatic Botany 47:53-60

Ryan ME, Johnson JR, Fitzpatrick BM (2009) Invasive hybrid tiger salamander genotypes impact native amphibians. Proceedings of the National Academy of Sciences of the United States of America 106:11166-11171

Santos AS, Godfrey MH (2001) Caretta caretta (loggerhead sea turtle) and Eretmochelys imbricata (hawksbill sea turtle). Predation. Herpetological Review 32:37

Schloesser, DW, Kovalak WP, Longton, GD, Ohnesorg KL, Smithee RD (1998) Impact of zebra and quagga mussels (Dreissena spp.) on freshwater unionids (Bivalvia:

Unionidae) in the Detroit River of the Great Lakes. The American Midland Naturalist 140:299-313

Scott TA, Morrison ML (1990) Natural History and Management of the San Clemente Loggerhead Shrike. Proceedings of the Western Foundation of Vertebrate Zoology 4:2357

Severns PM (2008) Exotic grass invasion impacts fitness of an endangered prairie butterfly, Icaricia icarioides fenderi. Journal of Insect Conservation 12:651-661

Severns PM, Warren AD (2008) Selectively eliminating and conserving exotic plants to save an endangered butterfly from local extinction. Animal Conservation 11:476-483

Shanahan SA, Nelson SM Van Dooremolen DM, Eckberg JR (2011) Restoring habitat for riparian birds in the lower Colorado River watershed: An example from the Las Vegas Wash, Nevada. Journal of Arid Environments 75:1182-1190

Swarts HM, Crooks KR, Willits N, et al. (2009) Possible contemporary evolution in an endangered species, the Santa Cruz Island fox. Animal Conservation 12:120-127

Thomson D (2005) Measuring the effects of invasive species on the demography of a rare endemic plant. Biological Invasions 7:615-624

Thomson, DM (2005) Matrix models as a tool for understanding invasive plant and native plant interactions. Conservation Biology 19:917-928

Timm, SF, Munson L, Summers BA, Terio, KA, Dubovi, EJ Rupprecht CE, Sanjay Kapil, S, Garcelon, DK (2009) A suspected canine distemper epidemic as the cause of a catastrophic decline in Santa Catalina island foxes (Urocyon littoralis catalinae). Journal of Wildlife Diseases 45: 333-343.

Uyehara KJ, Engilis Jr A, Dugger BD (2008) Wetland features that influence occupancy by the endangered Hawaiian duck. Wilson Journal of Ornithology 120:311-319 
Van Vuren D, Coblentz BE (1987) Some ecological effects of feral sheep on Santa Cruz Island, California, USA. Biological Conservation 41:253-268

Van Zwol JA, Neff BD, Wilson CC (2012) The influence of non-native salmonids on circulating hormone concentrations in juvenile Atlantic salmon. Animal Behaviour 83:119129

VanderWerf, EA (2009) Importance of nest predation by alien rodents and avian poxvirus in conservation of o'ahu 'elepaio. Journal of Wildlife Management 73:737-746

VanderWerf EA, Mosher, SM, Burt MD, Taylor PE (2011) Current distribution and abundance of o'ahu 'elepaio (Chasiempis ibidis) in the Wai'anae Mountains. Pacific Science 65: 311- 319 doi: 10.2984/65.3.311

Walker TL, Hoback WW (2007) Effects of invasive eastern redcedar on capture rates of Nicrophorus americanus and other Silphidae. Environmental Entomology 36:297-307

Wilcoxen TE, Rensel MA (2009) Invasive fire ants depredate nest of florida scrub-jay. Wilson Journal of Ornithology 121:846-847

Wiles GJ, Schreiner IH, Nafus D, et al. (1996) The status, biology, and conservation of Serianthes nelsonii (Fabaceae), an endangered Micronesian tree. Biological Conservation 76:229-239

Wiley JW, Post W, Cruz A (1991) Conservation of the yellow-shouldered blackbird Agelaius xanthomus, an endagered West Indian species. Biological Conservation 55:119-138 